\title{
arv 19096
}




\section{CORNELL UNIVERSITY LIBRARY}

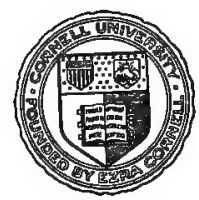

BOUGHT WI'TH THE INCOME OF THE SAGE ENDOWMENT FUND GIVEN IN 1891 BY HENRY WILLIAMS SAGE 

$\operatorname{arV} 19096$

Cornell University Library

An elementary text-book of botany,

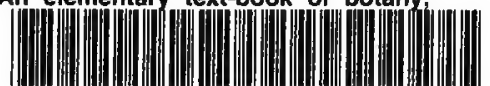

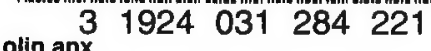




\section{Cornell University Library}

The original of this book is in the Cornell University Library.

There are no known copyright restrictions in the United States on the use of the text.

http://www.archive.org/details/cu31924031284221 





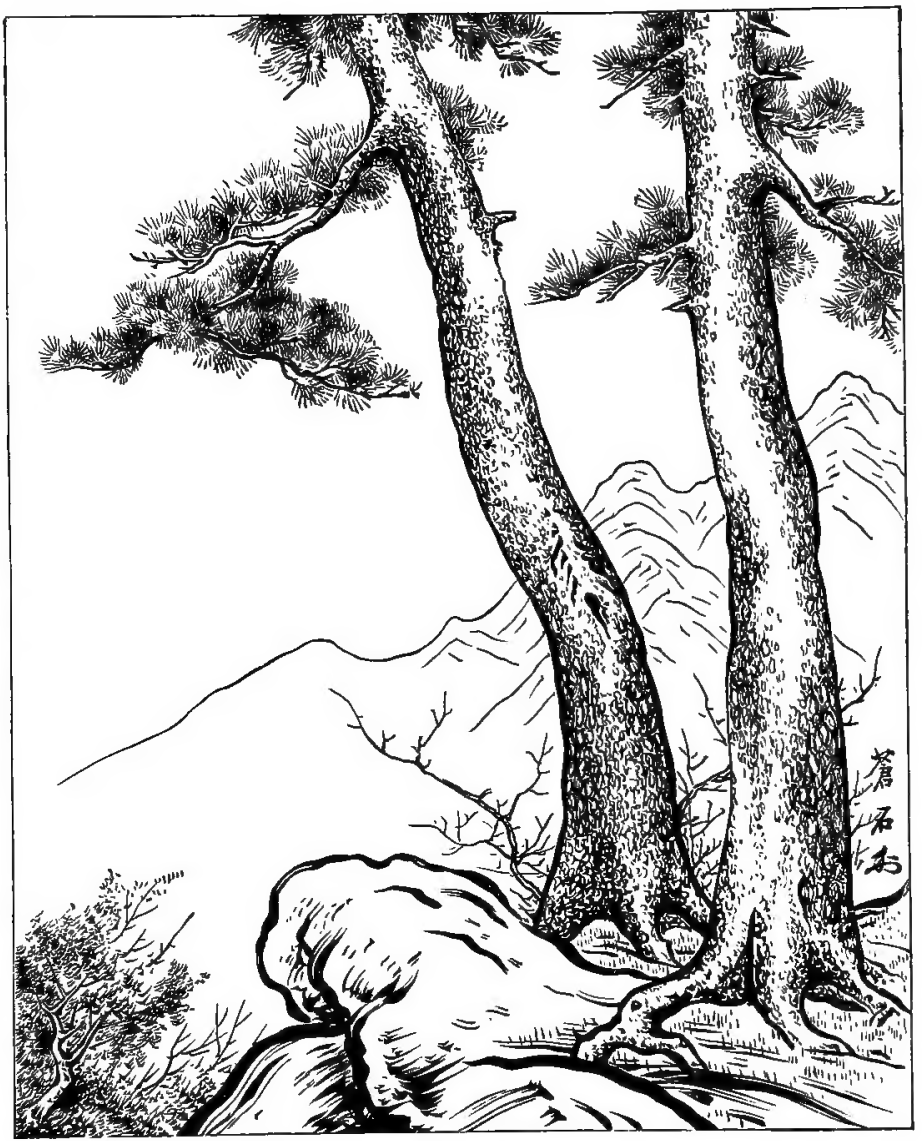

FIG. 1,-Akamatsu (Pinus densiflora). 


\title{
AN \\ ELEMENTARY TEXT-BOOK
}

OF

\section{BOTANY,}

FOR

\section{THE USE OF JAPANESE STUDENTS.}

\author{
BY
}

\section{KŌTARŌ SAIDA, Sc., D.,}

PEOFESSOR OF BOTANY IN THE HIGHER NORMAL SCHOOI, TOKYO;

MEMBER OF THE IMPERIAL MUSEUM, JAPAN ;

FELLOW OF THE TOKYO BOTANICAT SOCIETY;

FELLOW OF THE TOKYO ZOOLOGICAL SOCIETY.

AND

AKIOMI TAKAHASHI,

ABSISTANT PROFESSOR OF NATURAL HISTORY IN THE HIGHER NORMAL SCHOOL, TOKYO; FELLOW OF THE TOKYO BOTANICAL SOCIETY;

EELLOW OF THE TOKYO ZOOLOGICAL SOCIETY.

\section{TOKYO :}

XXVITH YEAR OF MEIJI (I 893). 



\section{PREFA CE.}

The science of Botany, like that of ather branches of Natural History, has two aspects: in one as a science of classification; and in the other as a science of observation, experiment, and induction. Not only are observation, experiment, and induction important processes in early education, but also to learn to classify is in itself an education. Moreover there is a great mass of useful knowledge embodied in Botany. The study of Botany, therefore, is an indispensable part of common education.

As we, in the first place, have aimed at rendering more effectual the lessons of Botany as a science of classification, applied to education, we had prepared this volume thoroughly on the logical system of classification, which embraces an enormous detail of subjects. In this volume, therefore, all facts and theories are arranged in one circle of system, without being separately treated, but exhibiting both their natural orders and relationships with each other.

We have wanted moreover to obtain the greatest effect of Botany as a science of experiment and induction, applied to education; consequently all explanations are accompanied by experiments and inductive generalization.

We have also taken care that, a fact should always precede its explanation, because the name is only an expression of a fact or idea. Failing to find suitable terms in many cases, we have selected them originally, and con- 
structed them, in a definite manner, from terms that always exist, although it was necessary sometimes to use two or more words, and thus the terms constructed have become long ones. There is a logical relation between a fact and its term, and the students may be taught this very easily.

We must express our thanks to $\mathrm{Mr}$. J. N. Seymour for his kindness in correcting the manuscript.

TokYo, FEBRUARY, XXVI⿳⺈.⿲㇒丨丶. YEAR OF MEIJI (1893). 


\section{CONTENTS.}

PAGT.

$\begin{array}{lllllllllll}\text { GENERAL } & \text { INTRODUCTION } & \ldots & \ldots & \ldots & \ldots & \ldots & \ldots & \ldots & \ldots & 1\end{array}$

\section{BOOK I.}

MORPHOLOGICAL BOTANY.

$\begin{array}{lllllll}\text { Introduction... } & \ldots & \ldots & \ldots & \ldots & \ldots \\ & & \text { CHAPTER } & \text { I. }\end{array}$

The Root

Sect. 1. Parts of the Root $\ldots$..

$\begin{array}{lllllllllllll}\# & 2 & \text { Texture } 0 f \operatorname{Roots} \ldots & \ldots & \ldots & \ldots & \ldots & \ldots & \ldots & \ldots & \ldots & \ldots & 7\end{array}$

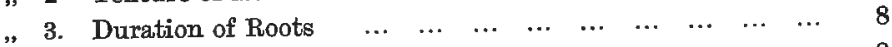

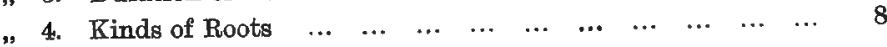

\section{CHAPTER II.}

$\begin{array}{lllllllllllll}\text { The Stem } & \ldots & \ldots & \ldots & \ldots & \ldots & \ldots & \ldots & \ldots & \ldots & \ldots & \ldots & 11\end{array}$

Sect. 1. Parts of the Stem...

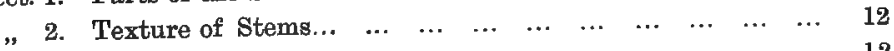

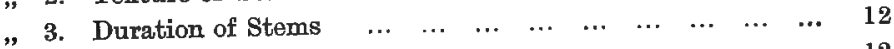

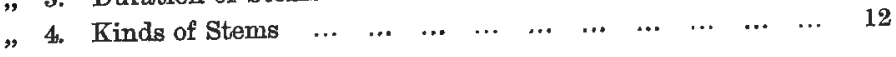

\section{CHAPTER III.}

The Leaf

, 2. Texture of Leares $\quad \ldots \quad$..

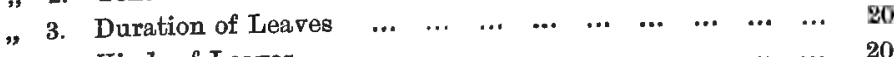

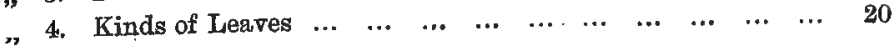




\section{CHAPTER IV.}

PAGIF.

$\begin{array}{lllllllllllll}\text { The Bud... } & \ldots & \ldots & \ldots & \ldots & \ldots & \ldots & \ldots & \ldots & \ldots & \ldots & \ldots & 89\end{array}$

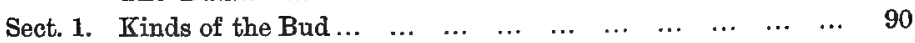

"2. The Præfoliation or Vernation...

\section{CHAPTER V.}

$\begin{array}{llllllllllllll}\text { Hairs } & \ldots & \ldots & \ldots & \ldots & \ldots & \ldots & \ldots & \ldots & \ldots & \ldots & \ldots & \ldots & 93\end{array}$

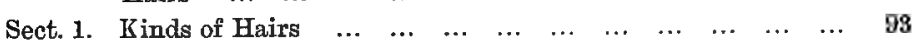

\section{BOOK II.}

HISTOLOGICAL BOTANY.

$\begin{array}{llllllllllll}\text { Introduction } \ldots & \ldots & \ldots & \ldots & \ldots & \ldots & \ldots & \ldots & \ldots & \ldots & \ldots & 97\end{array}$

\section{CHAPTER I.}

$\begin{array}{lllllllllllll}\text { The Cell... } & \ldots & \ldots & \ldots & \ldots & \ldots & \ldots & \ldots & \ldots & \ldots & \ldots & \ldots & 97\end{array}$

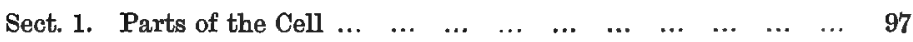

$\begin{array}{llllllllll} & \text { 2. Special Contents of the Cell } & \ldots & \ldots & \ldots & \ldots & \ldots & \ldots & \ldots & 103\end{array}$

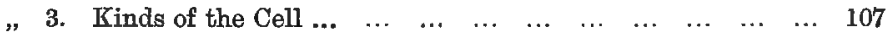

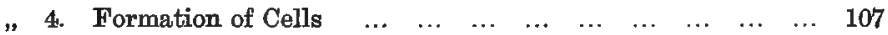

\section{CHAPPER II.}

$\begin{array}{llllllllllllll}\text { Tissues } & \ldots & \ldots & \ldots & \ldots & \ldots & \ldots & \ldots & \ldots & \ldots & \ldots & \ldots & \ldots & 110\end{array}$

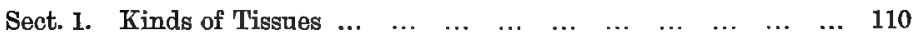

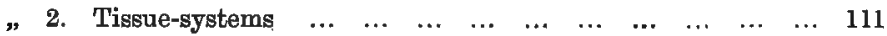

\section{CHAPTER III.}

$\begin{array}{lllllllllll}\text { Intercellular Spaces } & \ldots & \ldots & \ldots & \ldots & \ldots & \ldots & \ldots & \ldots & \ldots & 115\end{array}$

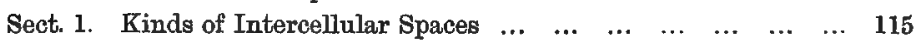

\section{B0OK III.}

PHYSIOLOGICAL BOTANY.

$\begin{array}{llllllllllll}\text { Introduction } \ldots & \ldots & \ldots & \ldots & \ldots & \ldots & \ldots & \ldots & \ldots & \ldots & \ldots & 117\end{array}$ 


\section{CHAPTER I.}

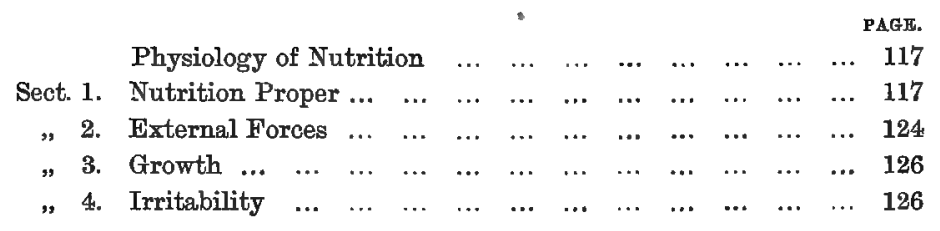

CHAPTER II.

$\begin{array}{lllllllll}\text { Physiology of Reproduction } & \ldots & \ldots & \ldots & \ldots & \ldots & \ldots & \ldots & 128\end{array}$

\section{B00K IV.}

SYSTEMATIC BOTANY.

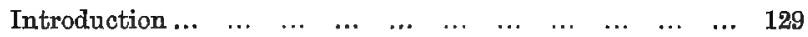

Chapter I.

$\begin{array}{llllllllllll}\text { Phanerogamæ } & \ldots & \ldots & \ldots & \ldots & \ldots & \ldots & \ldots & \ldots & \ldots & \ldots & 129\end{array}$

CHAPTER II.

$\begin{array}{lllllllllllll}\operatorname{Cryptogam} & \ldots & \ldots & \ldots & \ldots & \ldots & \ldots & \ldots & \ldots & \ldots & \ldots & \ldots & 134\end{array}$ 



\section{AN \\ ELEMENTARY TEXT BOOK \\ OF \\ BOTANY.}

\section{GENERAL INTRODUCTION.}

If such plants as the Mume (Prunus Mune), Sakura (Prunus pseudo-cerasus) (Fig. 2), Daikon (Raphanus sativus) (Fig. 6), and Nadzuna (Capsella bursa-pastoris) (Fig. 5) are examined, it will be seen that their outward forms differ more or less one from another.

If sections of the several parts of these plants are observed under the microscope, it will be found that they are internally formed of different minute structures.

If the living processes of these plants are thoroughly investigated, it will be known that they enlarge and increase their parts and reproduce their kinds.

Lastly, if these plants are compared, it will be recognized that the Mume has a much greater resemblance to the Sakura (Fig. 2) than to the others, and that the Daikon (Fig. 6) has a closer resemblance to the Nadzuna (Fig. 5).

The science, which deals with every thing that has reference to plants as seen in the above mentioned investigations, is called Botany. That department of the science which treats of the outward forms of plants is called Morphological Botany; that department which comprises 
the study of the internal structure of plants is called Histological Botany; that department which investigates. the living processes of plants is called Physiological Botany; and that department which considers plants as to their kinds and relationships is called Systematic Botany.

Fig. 2.

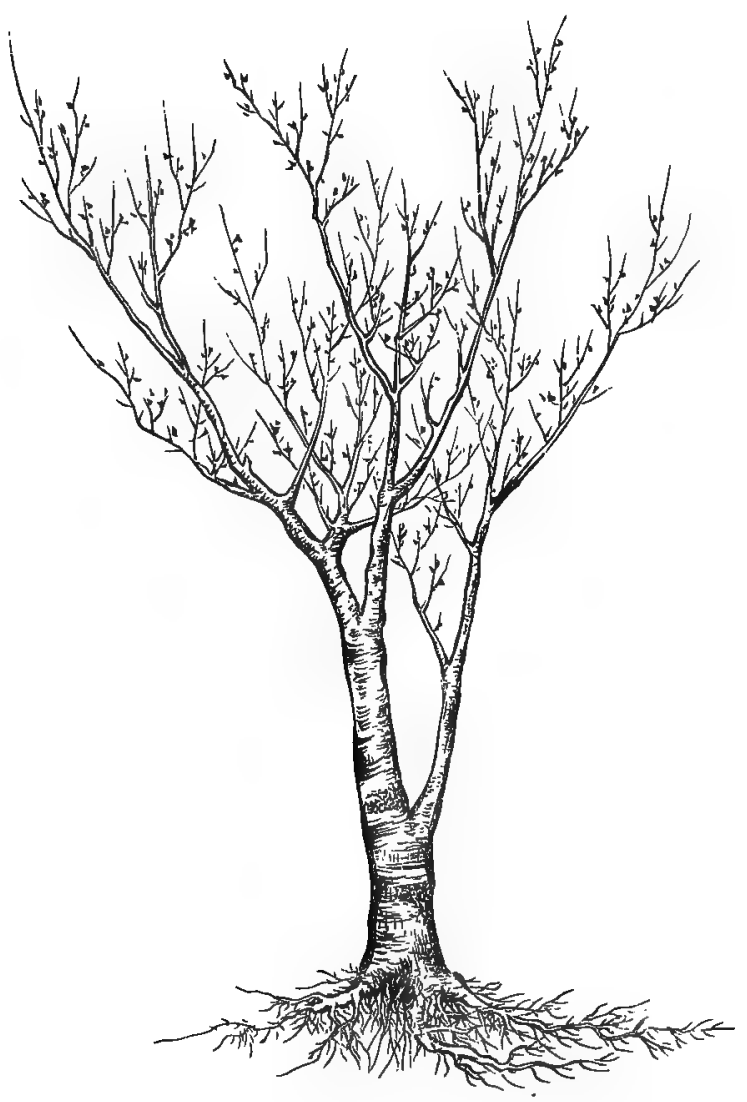

Fic. 2.-Sakura (Prunus psendo-cerasus). 
In Botany there are several öther departments:Geographical Botany, which treats of the distribution of plants over the surface of the earth at the present time; Fossil Botany, which considers the plants in a fossil state; and Applied Botany, which consists of the study of plants with special reference to various practical purposes. 


\section{BOOK I.}

\section{MORPHOLOGICAL BOTANY.}

\section{INTRODUCTION.}

If all the parts of such highly developed plants as the Nadzuna (Fig. 5), Daidzu (Glycine hispida), etc., are carefully observed by the unassisted eye, it will be seen that each plant consists of the axis, the upper portion of which is directed upwards and bears laterally green flat members, and the lower portion of which is directed downwards and does not bear those lateral appendages. That portion of the axis directed upwards and bearing green lateral members is called the Stem; that portion directed downwards and

Fir. 3.

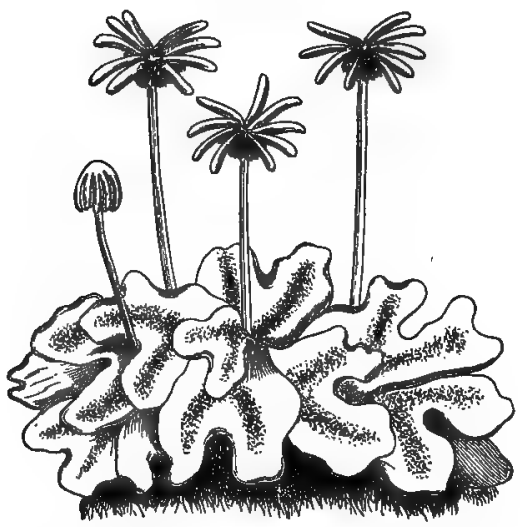

Fig. 3.-Zenigoke (Mar'chantia polymorpha). 
not bearing those lateral appendages, the Root; and the green flat lateral members or appendages on the stem, Leaves. Moreover small slender protuberances will be found on the surface of every part; these are called Hairs or Trichomes.

As seen in the preceding observations, most higher plants

FIg. 4.

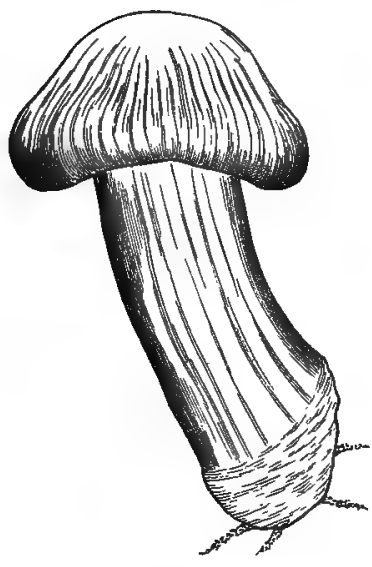
consist of four parts, namely, Roots, Stems, Leaves, and Hairs; but such lower plants as the Zenigoke (Marchantia polymorpha) (Fig. 3), Matsudake (Armillaria edodes) (Fig. 4), Kombu (Laminaria japonica) (Fig. 146), etc., do not present any differentiation into root, sten, and leaf, and the body of these plants is called a Thallus.

All the parts of the plant-body are represented in the following table.

Frg. 4.-Matsudake (Armillaria edodes).

$$
\text { PLANT-BODY }\left\{\begin{array}{l}
\text { With differentiation ...... } \begin{array}{l}
\text { Root. } \\
\text { Stem. } \\
\text { Leaf. } \\
\text { Hair. }
\end{array} \\
\text { Without differentiation......Thallus. }
\end{array}\right.
$$


F'IG. 5.

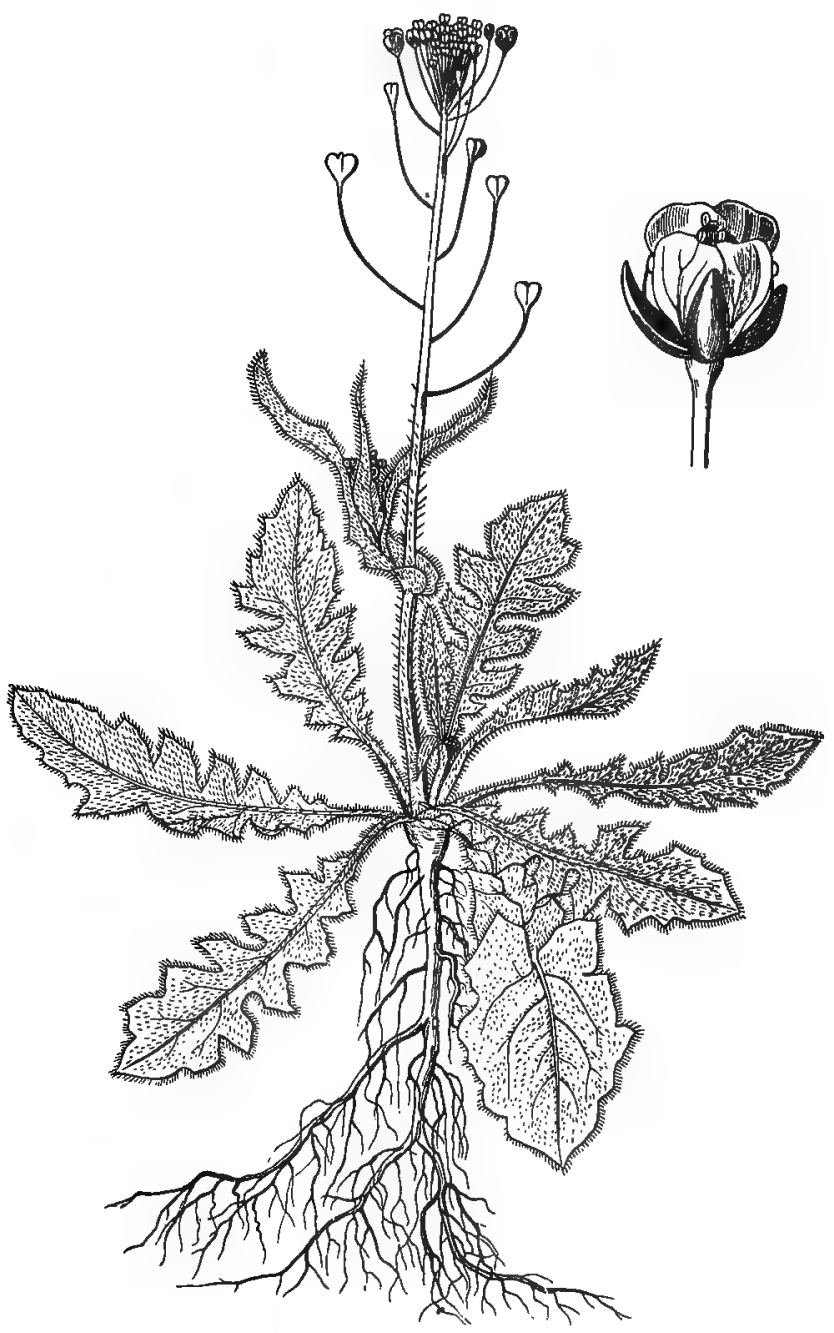

Fig. 5.-Nadzuna (Capsella bur'sa-pastoris). 


\section{CHAPTER I.}

\section{THE ROOT.}

The Root is that part of the axis which never bears leaves; it usually grows downwards.

\section{Section 1. PARTS OF THE ROOT.}

The organically lower end of the root is called its Base; the opposite or organically upper end, its $A$ pex; and the portion lying between the two extremities, its Body. (See Fig. 5.)

$$
\text { Parts of the roOT }\left\{\begin{array}{l}
\text { Base. } \\
\text { Body. } \\
\text { Apex. }
\end{array}\right.
$$

Section 2. TEXTURE OF ROOTS.

The texture of roots is either, weak and delicate, as in the Daikon (Fig. 6), Ninjin (Daucus carota), and Kabura (Brassica campestris), or strong and hard, as in the Mume, Akamatsu (Pinus densiflora), and Sakura (Fig. 2). When weak and delicate the root is said to be Herbaceous, and when strong and hard it is said to be Woody.

TEXTURe of Roots $\left\{\begin{array}{l}\text { Herbaceous. } \\ \text { Woody. }\end{array}\right.$

FIG. 6.

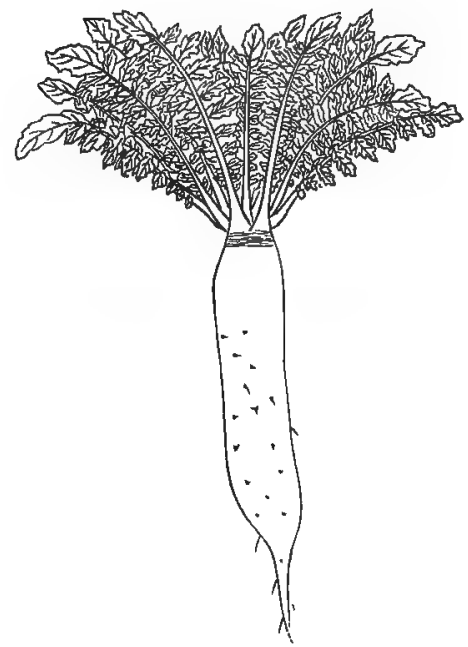

Fig. 6.-Daikon (Raphanus sativrs). 


\section{Section 3. DURATION OF ROOTS.}

'The duration of roots is various in different plants: some die the same year in which they are developed, as in the Asagao (Ipomcea triloba) (Fig. 9) and Kiuri (Cucumis sativus); some die the second year, as in the Daikon (Fig. 6) and Ninjin; and others live for many years, as in the Mume and Sakura (Fig. 2). 'Those which die the same year are said to be Annual; those which die the second year Biennial; and the others which live for many years Perennial.

$$
\text { DURATION OF ROOTs }\left\{\begin{array}{l}
\text { Annual. } \\
\text { Biennial. } \\
\text { Perennial. }
\end{array}\right.
$$

Section 4. KINDS OF ROOTS.

The root is various in reference to the medium in which it lives and the position from which it originates; hence it may be classified in two ways.

FIG. 7.

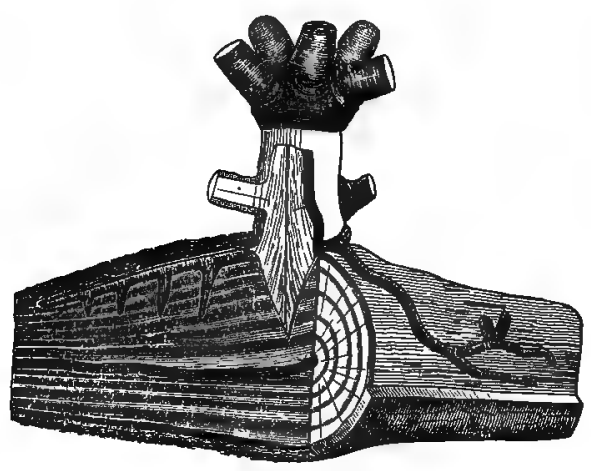

Fra. 7.-Parasitic root of the Yadoriki (Tiscum album). (Sachs.) 
1. KINDS OF ROOTS IN REFERENCE TO THE MIEDIUM.

The root exists either penetrating into another plant, as in the Yadoriki (Viscum album) (Fig. 7) and Nenashikadzura (Cuscuta japonica), or entirely free from another, as in the Mume and Sakura (Fig. 2); the former kind is called the Parasitic Root, and the latter the Independent Root.

Krnds of RoOTS IN REFERENCE / Parasitic Root. TO THE MEDIUM \{Independent Root.

Of the independent roots, ordinary ones bury themselves in the soil, as in the Asagao (Fig. 9) and Sakura (Fig. 2), while some exist submersed in water, as in the Hishi (Trapa bispinosa) (Fig. 8) and Ukikusa (Lemna minor),

\section{Frg. 8.}

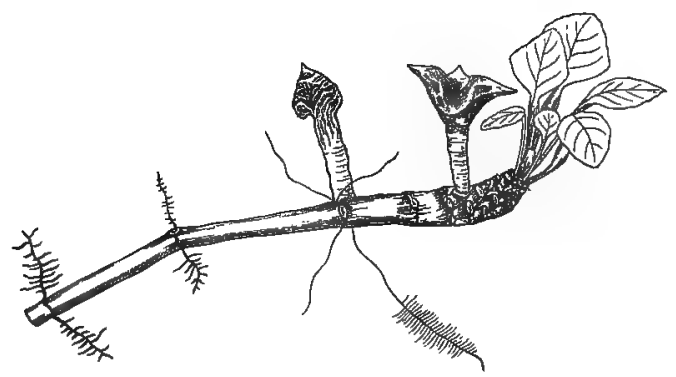

F1G. 8.-Hishi ('Trapa bispinosa), showing the aquatic roots and stem.

and others hang in the air, as in the Füran (Angracum falcatum) and Sekikoku (Dendrobium moniliforme). Those burying themselves in the soil are called Terrestrial Roots, those existing in water.Aquatic Roots, and those hanging in the air Aerial Roots.

$$
\text { INDEPENDIENT ROOT }\left\{\begin{array}{l}
\text { Terrestrial Root. } \\
\text { Aquatic Root. } \\
\text { Aerial Root. }
\end{array}\right.
$$


Different kinds of roots in reference to the medium are represented in the following table.

$$
\begin{aligned}
& \text { KINDS OF ROOTS IN } \\
& \text { REFERENCE } \\
& \text { THE MEDIUM }
\end{aligned} \text { To }\left\{\begin{array}{l}
\text { Parasitic Root. } \\
\text { Independent Root }\left\{\begin{array}{l}
\text { Terrestrial Root. } \\
\text { Aquatic Root. } \\
\text { Aerial Root. }
\end{array}\right.
\end{array}\right.
$$

2. KINDS OF ROOTS IN REFERENCE TO THE POSITION.

The root is developed either in the same straight line with the stem, or laterally on the other root, stem, or leaf. That which is developed in the same straight line with the stem is called the Tap-root, and the other which is developed laterally on the other root, stem, or leaf, is called the Lateral Root. (See Fig. 5.)

\section{KINDS OF ROOTS IN IREFERENCE Tap-root. TO THE POSITION $\{$ Lateral Root.}

\section{SUMMARY.}

The root is that part of the axis which never bears leaves.

The base of the root is its organically lower end.

The apex of the root is its organically upper end.

The body of the root is the portion lying between the base and the apex.

The root is said to be herbaceous when its texture is weak and delicate.

The root is said to be voody when its texture is strong and hard.

The root is said to be annual when it dies the same year in which it is developed.

The root is said to be biennial when it dies the second year.

The root is said to be perennial when it lives for many years.

The parasitic root is one which penetrates into another plant.

The independent root is one which exists entirely free from any other plant.

The terrestrial root is one which buries itself in the soil.

The aquatic root is one which exists in water.

The aerial root is one which hangs in the air.

The tap-root is one which is developed in the same straight line with the stem.

The lateral root is one which is developed laterally on the other root, stem, or leaf. 


\section{CHAPTER II.}

\section{THE STEII.}

The Stem is that part of the axis which always bears leaves; it usually grows upwards.

Section 1. PARTS OF THE STEM.

The organically lower end of the stem is called its Base; FIG. 9.
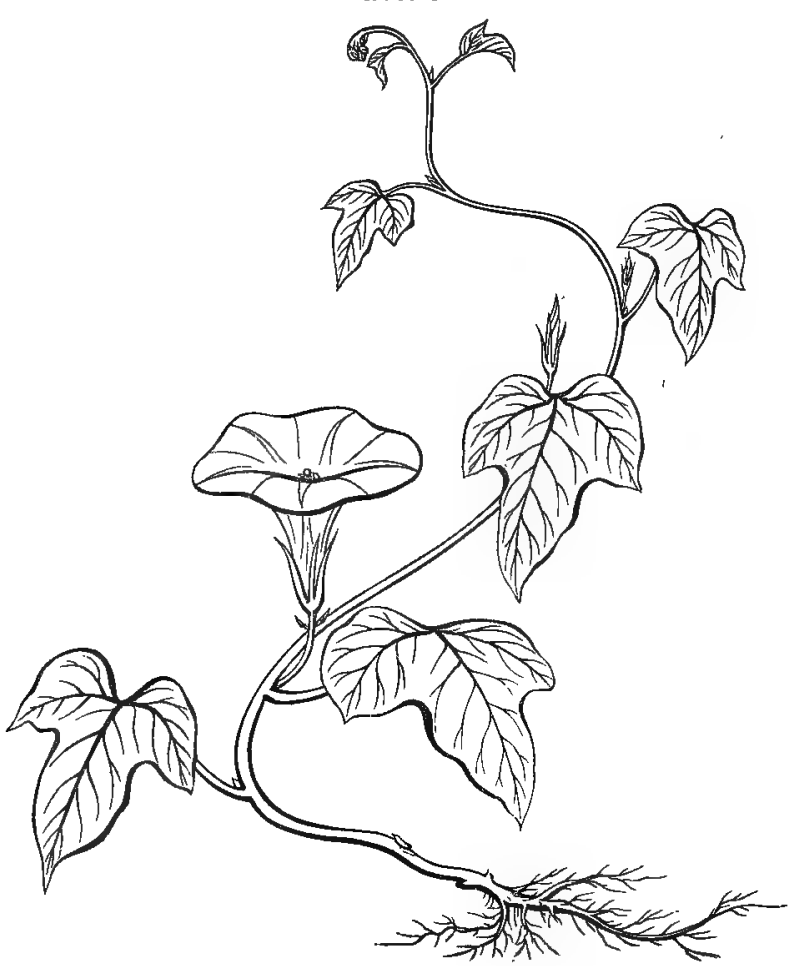

FIG. 9.-Asagao (Ipomad triloba). 
the opposite or organically upper end, its Apex; the portion lying between the two extremities, its Body; the portion where leaves are borne, a Node; and the interval between two nodes, an Internode. (See Fig. 9.)

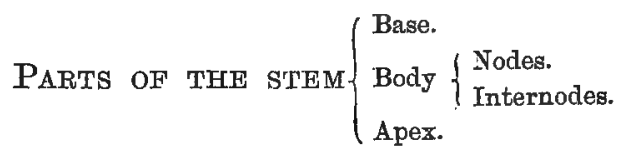

Section 2. TEXTURE OF STEMS.

The texture of stems is also either weak and delicate, as in the Asagao (Fig. 9) and Nadzuna (Fig. 5), or strong and hard, as in the Akamatsu (Fig. 1) and Sakura (Fig. 2); when weak and delicate, the stem is said to be Herbaceous, and when strong and hard, it is said to be Woody.

$$
\text { TextuRE OF STEMS }\left\{\begin{array}{l}
\text { Herbrceous. } \\
\text { Woody. }
\end{array}\right.
$$

\section{Section 8. DURATION OF STEMS.}

The duration of stems is also various in different plants : some die the same year in which they are developed, as in the Asagao (Fig. 9) and Kiuri; some die the second year, as in the Daikon (Fig. 6) and Ninjin; and others live for many years, as in the Akamatsu (Fig. 1) and Sakura (Fig. 2). Those which die the same year are said to be Annual; those which die the second year Biennial; and the others which live for many years Perennial.

$$
\text { Doration of stems }\left\{\begin{array}{l}
\text { Annual. } \\
\text { Biennial. } \\
\text { Perenniak. }
\end{array}\right.
$$

\section{Section 4. KINDS OF STEMS.}

The stem is also various according to the medium in which it lives and the position from which it originates, so that it may be classified in two ways. 
1. KINDS OF STEMS IN REFERENCE TO THE MEDIUM.

The stem may exist either exposed to the air, as in the Mume and Sakura (Fig. 2), or buried in the soil, as in the Satoimo (Colocasia antiquorum) (Fig. 13) and Ayame (Iris sibirica), or submersed in water, as in the Sasamo (Potamogeton oxyphyllus) and Hishi (Fig. 8). That which exists exposed to the air is called the Aerial Stem; that which exists buried in the soil, the Subterranean Stem; and that which exists submersed in water, the Aquatic Stem.

\section{KINDS OF STEMS IN REHERENCE (Aerial Stem. TO THE MEDIUM \\ Subterranean Stem. Aquatic Stem.}

The aerial stem may be either Herbaceous, as in the Asagao (Fig. 9) and Nadzuna (Fig. 5), or Woody, as in the Mume and Sakura (Fig. 2). Plants having herbaceous stems are called Herbs, and those having well developed woody stems Trees. Trees are all perennial, but herbs are very various, being annual, biennial, or sometimes perennial. In trees both roots and stems are perennial, while in perennial herbs the underground portions only survive, all the parts above ground usually dying after once fruiting.

$$
\text { AfRIAL STEM }\left\{\begin{array}{l}
\text { Herbaceous Stem. } \\
\text { Woody Stem. }
\end{array}\right.
$$

Among herbaceous stems, some can raise themselves up without any support, as in the Ine (Oryza sativa) (Fig. 10) and Nadzuna (Fig. 5), while others can only raise themselves up by means of supports, as in the Asagao (Fig. 9) and Shiode (Smilax herbacea) (Fig. 52); the former are called Independent Herbaceous Stems, and the latter Dependent or Climbing Herbaceous Stems. 
Herbaceous stem $\left\{\begin{array}{l}\text { Independent Herbaceous Stem. } \\ \text { Dependent Herbaceous Stem. }\end{array}\right.$

FIa. 10.

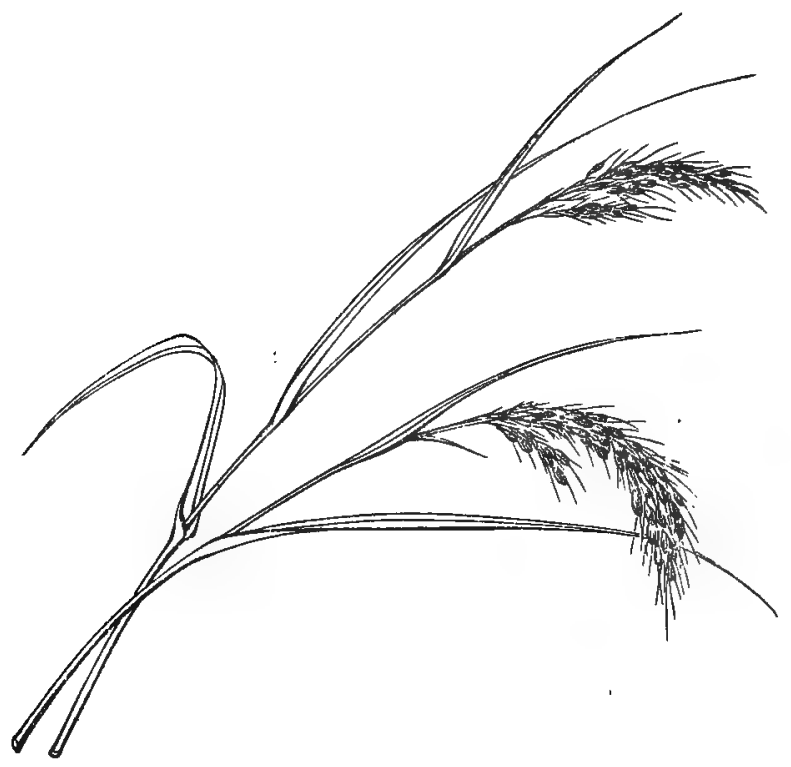

Fia. 10.-Ine (Oryza sativa).

Among woody stems also, some can raise themselves up without any support, as in the Akamatsu (Fig. 1) and Sakura (Fig. 2), while others can only raise themselves up by means of supports, as in the Budo (Vitis vinifera) (Fig. 15) and Kidzuta (Hedera Helix); the former are called Independent Woody Stems, and the latter Dependent or Climbing Woody Stems.

WoODY STEM $\left\{\begin{array}{l}\text { Independent Woody Stem. } \\ \text { Dependent Woody Stem. }\end{array}\right.$ 
The subterranean stem exists buried in the soil and very much resembles the root, but it is easily distinguished from the latter, by the presence of either leaves, or leaf-scars.

Among subterranean stems, some are long and closely resemble roots, as in the Hakuka (Mentha arvensis) and

FIG. 11.

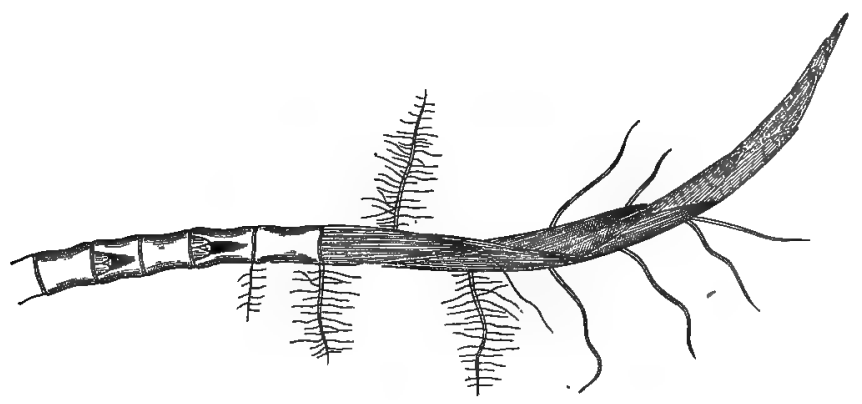

Fra. 11.-Rhizome of the Take (Bambusa).

FIG. 12.

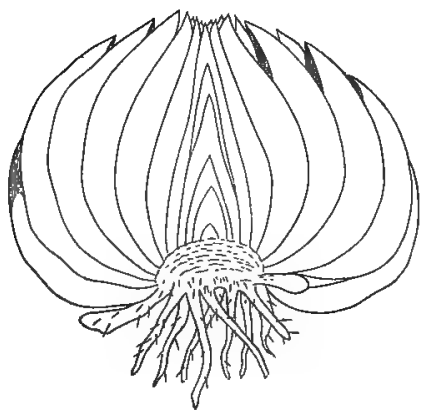

Fig. 12.-Bulb of the Oniyuri (Lilizm tigrinum) with fleshy leaves.

Take (Bambusa) (Fig. 11); some are short and surrounded either by many fleshy leaves, as in the Oniyuri (Lilium tigrinum) (Fig. 12), or by only a few leaves more delicate, 
as in the Satoimo (Fig. 13); and others are much thickened and fleshy, with usually very small leaves, as in the JagaFIG. 13.

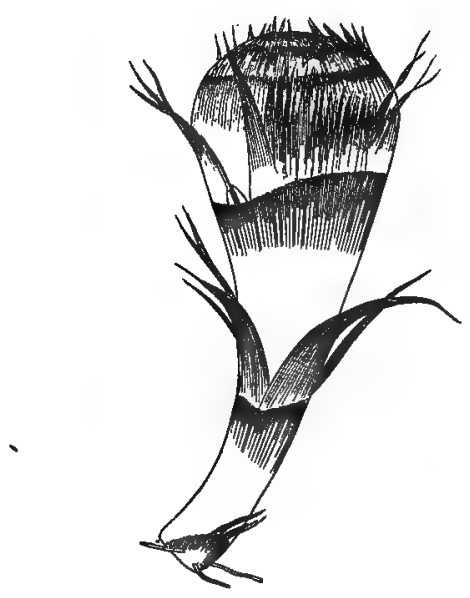

Fig. 13.-Bulb of the Satoimo (Colocasia antiquomim) with membranous leaves.

Fra. 14.

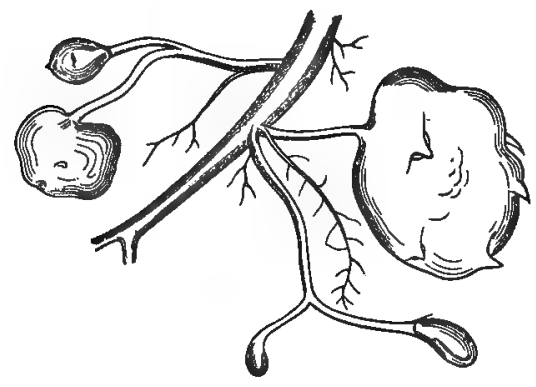

FIt. 14.-T'ubers of the Jagataraimo (Solanum tuberosum) with minute subterranean leaves.

taraimo (Solanum tuberosum) (Fig. 14) and Kikuimo (Helianthus tuberosus). Those which are long are called 
Rhizomes; those which are short and surrounded by leaves, Bulbs; and the others which are much thickened and fleshy, with very small leaves, Tubers.

$$
\text { SUbTerRaneaN sTEM }\left\{\begin{array}{l}
\text { Rhizome. } \\
\text { Bulb. } \\
\text { Tuber. }
\end{array}\right.
$$

Fra. 15.

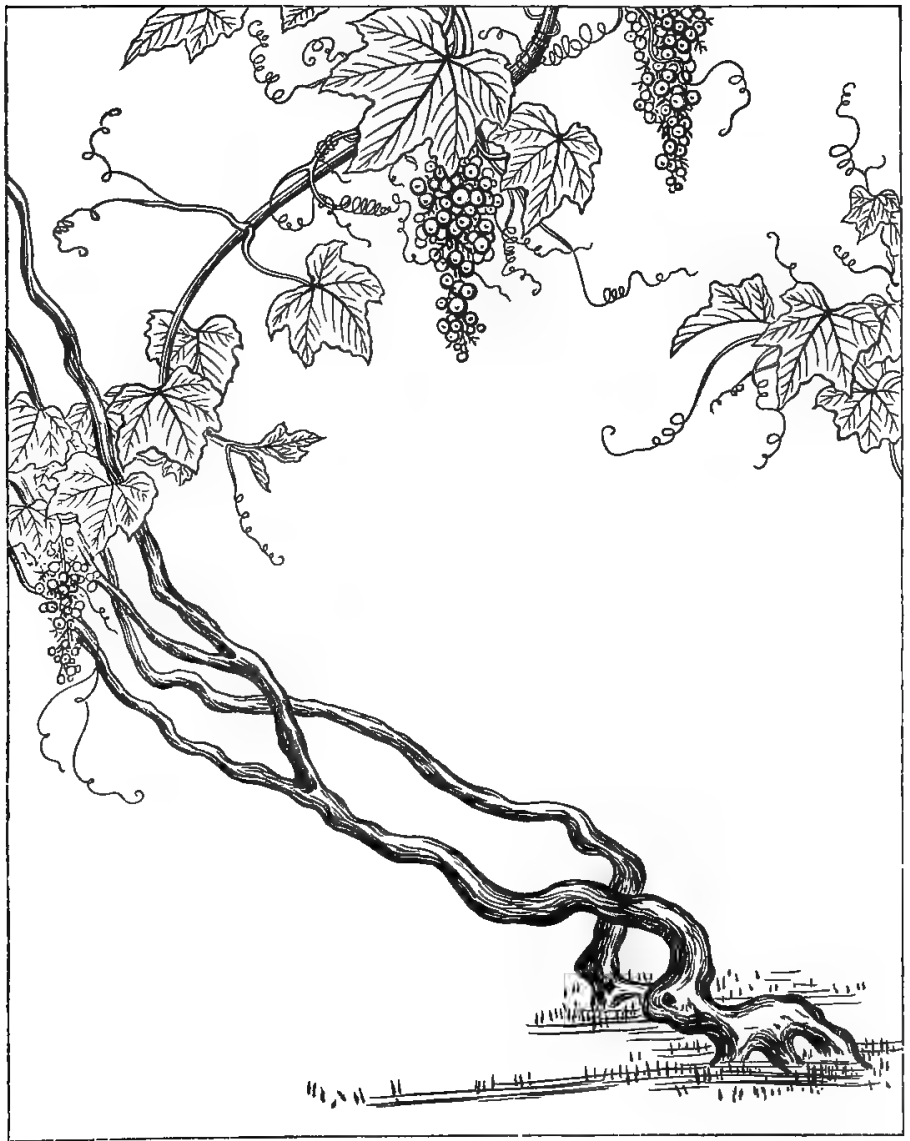

F'ı. 15.-Budō (Vitis vinifera). 
Different kinds of stems according to the medium are represented in the following table.

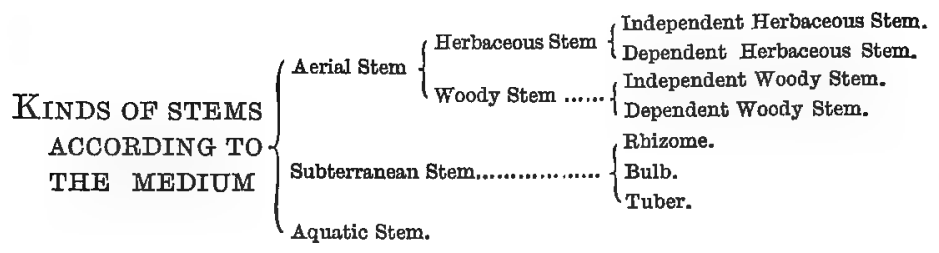

2. KINDS OF STEMS IN REFERÉNCE TO THE POSITION.

The stem is developed either as the main axis, which is sometimes connected and sometimes not connected with the tap-root, or laterally on the other stem, root, or leaf. 'That which is developed as the main axis is called the Trunk or Main Stem, and the other, which is developed laterally on the other stem, root, or leaf, is called the Lateral stem or Branch.

\section{KINDS OF STEM IN REFERENCE $\{$ Main Stem. \\ TO THE POSITION $\{$ Lateral Stem.}

\section{SUMMARY.}

The stem is that part of the axis which always bears leaves.

The base of the stem is its organically lower end.

'The apex of the stem is its organically upper end.

The body of the stem is the portion lying between the base and the apex.

The node is that portion of the body of the stem where leaves are borne.

The internode is the interval between two nodes.

The stem is said to be herbaceous when its texture is weak and delicate.

The stem is said to be woody when its texture is strong and hard.

The stem is said to be annual when it dies the sume year in which it is developed.

The stem is said to be biennial when it dies the second year.

The stem is said to be perennial when it lives for many years.

The aerial stem is one which exists exposed to the air.

The subterranean stem is one which exists buried in the soil. 
The aquatic stem is one which exists submersed in water.

The herb is a plant having an herbaceous stem.

The tree is a plant having a wondy stem.

The independent herbaceous stem is one which is herbaceous and can raise itself up without any support.

The dependent herbaceous stem is one which is herbaceous and can only raise itself up by means of supports.

The independent woody stem is one which is woody and can raise itself up without any support.

The dependent voody stem is one which is woody and can only raise itseli up by means of supports.

The rhizome is a subterranean stem which is long and root-like.

The bulb is a subterranean stem which is short and surrounded by leaves.

The tuber is a subterranean stem which is thick and fleshy with very small leaves.

The main stem is one which is developed as the main axis which is sometimes connected and sometimes not connected with the tap-root.

The lateral stem is one which is developed laterally on the other stem, root, or leaf.

\section{CHAPTER III.}

\section{THE LEAF.}

The Leaf is always developed laterally on the stem and is usually of a flattened nature.

\section{Section 1. PARTS OF THE LEAF.}

The organically lower end of the leaf where it is attached to the stem is called its Base; the opposite or organically upper end, its Apex; and the portion lying between the two extremities, its Body. (See Fig. 16.)

$$
\text { 'Parts of the leafi }\left\{\begin{array}{l}
\text { Base. } \\
\text { Body. } \\
\text { Apex. }
\end{array}\right.
$$




\section{Section 2. TEXTURE OF LEAVES.}

The texture of leaves is either tough and leathery, as in the Tsubaki (Camellia japonica) and Yudzuriha (Daphniphyllum macropodum) (Fig. 25), weak and soft, as in the Sakura (Fig. 16) and Asagao (Fig. 9), thick and juicy, as in the Benkeiso (Sedum alboroseum) and in the bulbs of the Oniyuri (Fig. 12), or thin and flexible, as the underground leaves of the Negi (Allium fistulosum) and Satoimo (Fig. 13). When tough and leathery the leaf is said to be Coriaceous ; when weak and soft it is said to be Herbaceous ; when thick and juicy it is said to be Succulent; and when thin and flexible it is said to be Membranous.

$$
\text { TExTURE OF LEAVES }\left\{\begin{array}{l}
\text { Coriaceous. } \\
\text { Herbaceous. } \\
\text { Succulent. } \\
\text { Membranous. }
\end{array}\right.
$$

Section 3. DURATION OF LEAVES.

The duration of leaves is also different in different cases: some die the same year in which they are developed, as in the Asagao (Fig. 9) and Salura (Fig. 16); some die the second year, as in the Ninjin and Yudzuriha (Fig. 25); and others live for many years, as in the Asunaro (Thuya dolabrata) and Sugi (Cryptomeria japonica). Those which die the same year are said to be Annual; those which die the second year Biennial; and the others which live for many years Perennial.

$$
\text { DURATION OF LEAVES }\left\{\begin{array}{l}
\text { Annual. } \\
\text { Biennial. } \\
\text { Perennial. }
\end{array}\right.
$$

\section{Section 4. KINDS OF LEAVES.}

The leaf is various according to the medium in which it lives and the function which it performs, so that it may be classified in two ways. 
1. KINDS OF LEAVES IN REFERENCE TO I'HE MEDIUM.

The leaf may exist either exposed to the air, as in the ordinary case, or submersed in water, as in the Sasamo and Midzuobako (Ottelia japonica), or buried in the soil, as in the subterranean stems of the Oniyuri (Fig. 12) and Jagataraimo (Fig. 14).

That which exists exposed to the air is called the Aerial Leaf ; that which exists submersed in water, the Aquatic Leaf ; and that which exists buried in the soil, the Subterranean Leaf.

$$
\begin{gathered}
\text { KINDS OF LEAVES IN REFERENCE } \\
\text { TO THE MEDIUM }
\end{gathered}\left\{\begin{array}{l}
\text { Aerial Leaf. } \\
\text { Aquatic Leaf. } \\
\text { Subterranean Leaf. }
\end{array}\right.
$$

2. KINDS OF LEAVES IN REFERENCE TO THE FUNCTION.

Ordinary leaves are green, mostly flattened, and their functions are not related to reproduction. Such leaves are called Foliage Leaves. There are other leaves which have reproductive or protective functions, or which are insectivorous, or merely rudimentary, or varied in some other way. These are called Modified Leaves.

KINDS OF LEAVES IN REFERENCE \{ Foliage Leaf. TO THE FUNCTION $\quad$ Modified Leaf.

\section{A. THE FOLIAGE LEAF.}

The Foliage Leaf is always green, mostly flattened, and does not produce reproductive organs; it has usually such two surfaces as one is turned upwards and the other downwards.

\section{PARTS OF THE FOLIAGE LEAF.}

In the most highly developed foliage leaf, its lower portion, including the base, is more or less dilated so as to embrace the stem, from which it springs; its upper portion, includ- 
ing the apex, is usually expanded and flattened; and its middle portion is narrower and commonly semicylindrical. The expanded upper portion is called the Lamina or Blade,

FIG. 16.

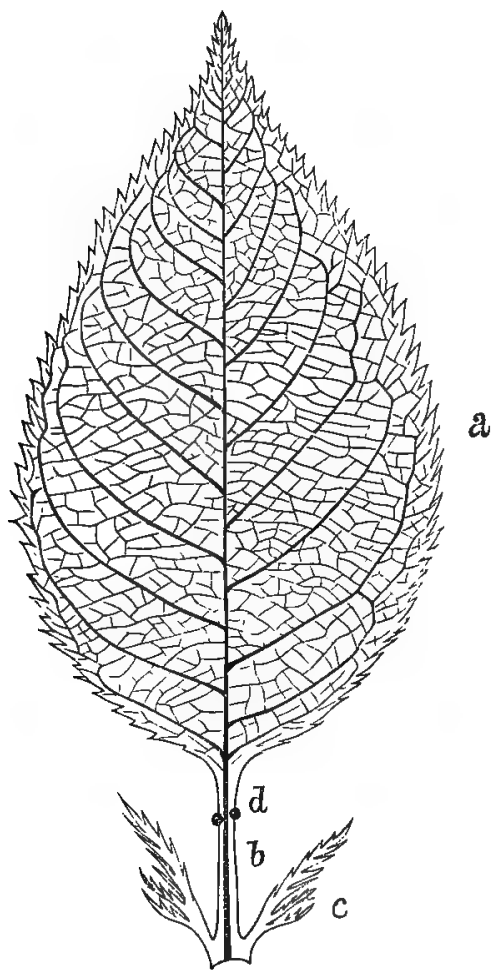

Fig. 16.-Herbaceous, annual, dentate, and pinnately reined leaf of the Sakura. a Lamina; b petiole; c leaf-sheath with stipules; d glands.

the narrower middle portion the Petiole or Leaf-stalk, and the sheath-like lower portion the Leaf-sheath. (See Fig. 16.) These three portions are not, however, developed in all leaves: in some leaves the leaf-sheath is absent as in those 
of the Momiji (Acer palmatum) (Fig. 18); in some the petiole is absent as in those of the Ine (Fig. 10); and in others both the petiole and leaf-sheath are absent as in those of the Doku-utsugi (Coriaria japonica) (Fig. 19).

$$
\text { Parts OF the Foliage LEAF }\left\{\begin{array}{l}
\text { Lamina. } \\
\text { Petiole. } \\
\text { Leaf-sheath. }
\end{array}\right.
$$

a. The Lamina.

The Lamina is the most important part of the foliage leaf and is usially expanded and flattened.

\section{PARTS OF THE LAMINA.}

The organically lower end of the lamina, where it is connected with the petiole in a well developed leaf, is called its Base; the opposite or organically upper end, its Apex; the lines connecting the two extremities, its Margins; and the portion enclosed within the margins, its Body. (See Fig. 16.)

$$
\text { PARTS OF THE LAMINA }\left\{\begin{array}{l}
\text { Base. } \\
\text { Body-Margins. } \\
\text { Apez. }
\end{array}\right.
$$

\section{VENATTON OR NERVATION.}

The skeleton of the lamina is composed of woody threadlike structures which are called Veins, and the modes of their distribution are called Venation. Large veins, proceeding from the base to the apex of the lamina, are called Ribs, and the most prominent central vein is called the Midrib.

The veins are distributed either anastomosing so as to form a kind of network as in the leaves of the Sakura (Fig. 16) and Momiji (Fig. 18), or more or less parallel to one another as in the leaves of the Ine (Fig. 10) and Maidzurusō 
(Maianthemum bifolium) (Fig. 17); when distributed as in the former case the venation is said to be Reticulated- or FIG. 17.

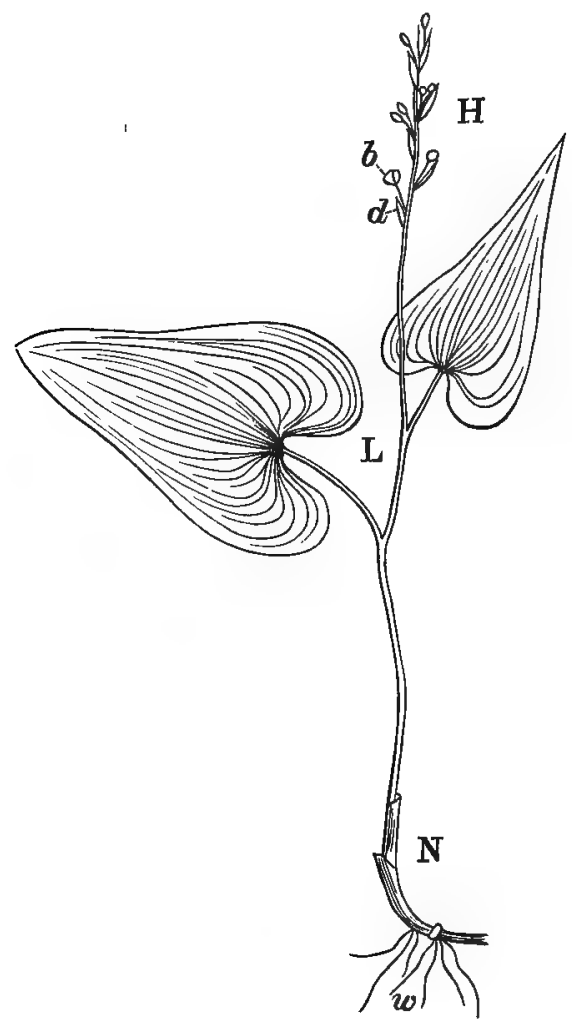

FIG. 17.-Maidzurusō (Maianthemum bifolium).

$H$ Portion of the stem with reproductive modified leaves; $b$ flower;

d scattered bract; $L$ portion of the stem with foliage leaves;

$N$ portion of the stem with cataphyllary leaves; $w$ roots. (Prantl.)

Netted-veined, and when distributed as in the latter it is said to be Parallel-veined.

$$
\text { VEnation }\left\{\begin{array}{l}
\text { Netted-veined. } \\
\text { Parallel-veined. }
\end{array}\right.
$$


Among netted-veined laminae, some have but one rib, as those of the Mume and Sakura (Fig. 16), while others more than one, as those of the Momiji (Fig. 18) and Yatsude

FIa. 18.



Fra. 18.-Divergipalmately veined and parted leaf of the Momiji (Acer palmatum).

(Fatsia japonica); when one-ribbed the venation is said to be Pinnately or Unicostately Veined, and when severalribbed Palmately or Multicostately Veined.

$$
\text { NE'TTED-VEINED }\left\{\begin{array}{l}
\text { Pinnately Veined. } \\
\text { Palmately Veined. }
\end{array}\right.
$$

Among palmately netted-veined laminae, some have diverging ribs, as those of the Momiji (Fig. 18) and Yatsude, and others converging ribs, as those of the Doku-utsugi (Fig. 19) and Obako (Plantago asiatica); in the former case the venation is said to be Divergipalmately Veined, and in the latter it is said to be Convergipalmately Veined. 
PaLmately veined $\left\{\begin{array}{l}\text { Divergipalmately Veined. } \\ \text { Convergipalmately Veined. }\end{array}\right.$

FIG. 20.

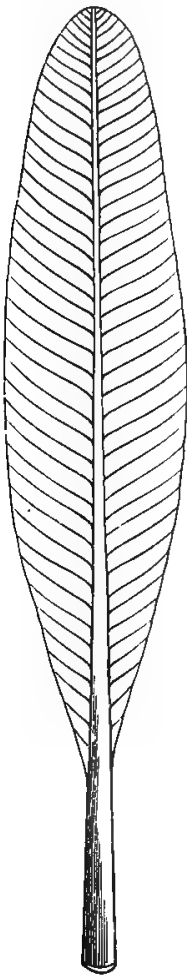

Fra. 20.-Costal-nerved leaf of the Bashō (Musa Basjoo).

FIg. 19.

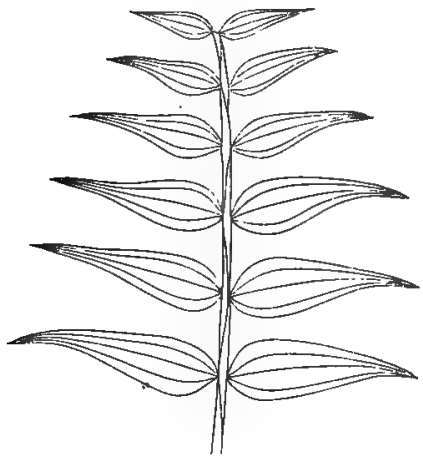

Fig. 19.-Shoot'of the Doku-utsugi (Coriaria japonica) with convergipalmately veined leaves.

Fig. 21.

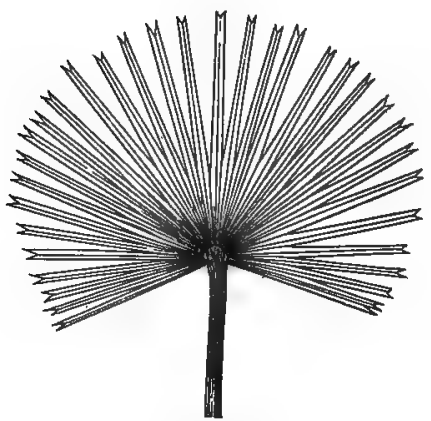

Fra. 21.-Flabellinerved leaf of the Shuro (Trachycarpus excelsa).

Among parallel-veined laminae also, some have but one rib, as those of the Basho (Musa Basjoo) (Fig. 20) and Shōga (Zingiber officinale), while others more than one, as. 
those of the Maidzuruso (Fig. 17) and Shuro (Trachycarpus excelsa) (Fig. 21); when one-ribbed the venation is said to be Costal-nerved, and when several-ribbed Basal-nerved.

$$
\text { Parallel-veIned }\left\{\begin{array}{l}
\text { Costal-nerved. } \\
\text { Basal-nerved. }
\end{array}\right.
$$

Among basal-nerved laminae also, some have diverging ribs, as those of the Shuro (Fig. 21) and Ichō (Ginkgo biloba), and others converging ribs, as those of the Maidzuruso (Fig. 17) and Ine (Fig. 10); in the former case the venation is said to be Flabellinerved, and in the latter it is said to be Longitudinal-nerved.

$$
\text { BASAL-NERVED }\left\{\begin{array}{l}
\text { Flabellinerved. } \\
\text { Longitudinal-nerved. }
\end{array}\right.
$$

All the kinds of venation are represented in the following table.

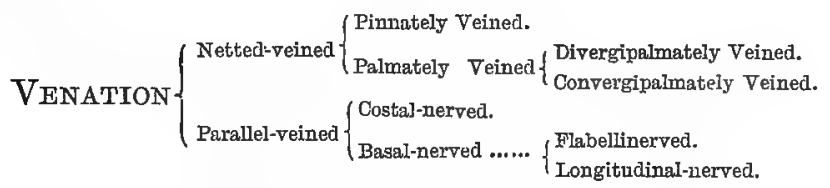

3. FORMS OF THE LAMINA.

The lamina is mostly of such a form that it can be divided longitudinally into two similar halves side by side, as those of the Sakura (Fig. 16) and Bashō (Fig. 20), but in some cases the halves are not similar, as those of the Shükaidō (Begonia Evansiana) (Fig. 22) and Nemu (Albizzia Julibrissin); when the halves are similar the lamina is said to be Symmetrical, and when they are not. similar Unsymmetrical.

$$
\text { ForMS OF THE LAMTNA }\left\{\begin{array}{l}
\text { Symmetrical. } \\
\text { Unsymmetrical. }
\end{array}\right.
$$

Among symmetrical laminae, some can be divided again by a lateral (transverse) plane into two similar halves up. 
FIG. 22.

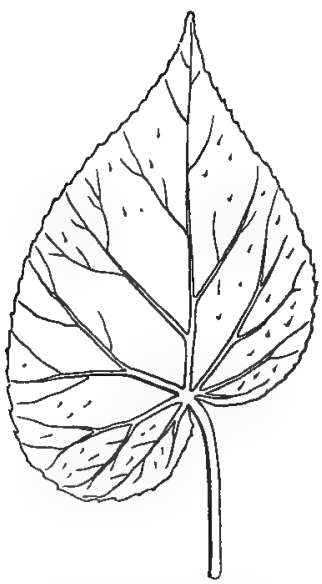

FIa. 22.-Unsymmetrical leaf of the Shūkaido (Begonia Evansiana). and down, as those of the Hasu (Nelumbium speciosum) (Fig. 23) and Inutsuge (Ilex crenata) (Fig. 24), while others, as those of the Natsume (Zizyphus vulgaris) (Fig. 27) and Satoimo, can not be divided into such similar halves; the former are said to be Disymmetrical, and the latter Monosymmetrical.

$$
\text { SYMmETRICAL }\left\{\begin{array}{c}
\text { Disymmetrical } \\
\text { (Quadripartible). } \\
\text { Monosymmetrical } \\
\text { (Bipartible). }
\end{array}\right.
$$

The principal forms of disymmetrical laminae are Orbicular as in the Hasu (Fig. 13), Elliptical as in the Inutsuge

FIG. 23.

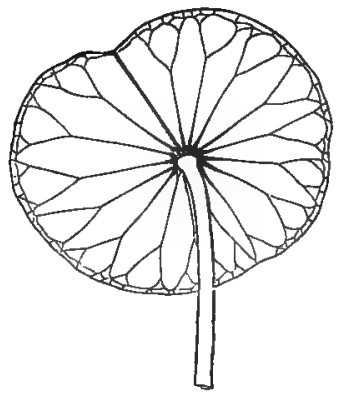

FiG. 23.-Orbicular leaf of the Hasu (Nelumbium speciosum).
FIG. 24.

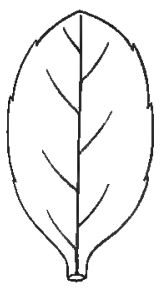

FIG. 24.-Elliptical leaf of the Inutsuge (Ilex crenata). 
(Fig. 24), Oblong as in the Yudzuriha (Fig. 25), and Linear as in the Koyamaki (Sciadopitys verticillata) (Fig. 26), etc.

Fig. 25.

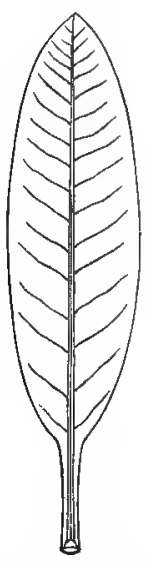

Fig. 25.-Coriaceous, biennial, entire, and oblong leaî of the Yudzuriha (Daphniplyyllum macropodum).
FIG. 26.

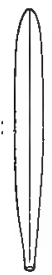

FIG. 26.-Linear leaf of the

Köyamaki

(Sciadopitys verticillata).

The principal forms of monosymmetrical laminae are Ovate as in the Mume and Natsume (Fig. 27), Obovate as in the Kobushi (Magnolia Kobus) (Fig. 28) and Mokuren (M. obovata), Lanceolate as in the Momo (Prunus persica) and Shidareyanagi (Salix babylonica) (Fig. 31), Oblanceolate as in the Yayemugura (Galium aparine) (Fig. 29) and Numatorano-o (Lysimachia Fortunei), Acerose as in the Sugi and Akamatsu (Fig. 32), Spathulate as in the Tabirako (Eritrichium pedunculare) (Fig. 30) and Darumagiku (Aster spathulifolius), Cordate as in the Satoimo and $\mathrm{K} \overline{\mathbf{u}}-$ hone (Nuphar japonicum) (Fig. 33), Reniform as in the Agisumire (Viola verecunda, var. semilunaris) and Kakidōshi (Nepeta Glechoma) (Fig. 34), Sagittate as in the 
Unagitsukami (Polygonum strigosum) (Fig. 35) and Nagahano-unagitsulkami ( $P$. sagittatum), and Hastate as in the Mizosoba (P. Thunbergii) and Iwaomodaka (Polypodium tricuspe) (Fig. 36), etc.

Fra. 27.

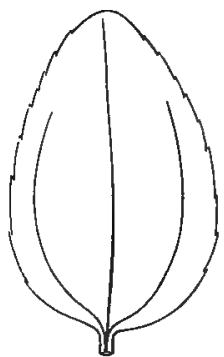

Fig. 27.-Ovate leaf of the Natsume (Zizyphus vulgaris).
FrG. 28.

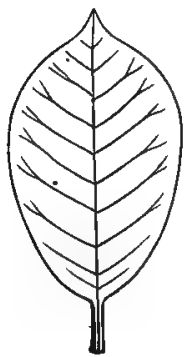

Fia. 28.-Obovate leaf of the Kobushi (Magnolia Kobus).
FIG. 29.

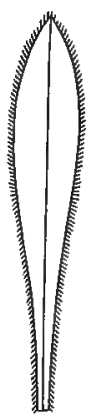

FIG. 30.

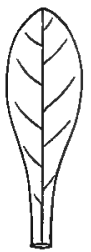

FIG. 30.-Spathulate leaf of the 'Tabirako (Eritrichium pedunculare). 
FIG. 33.

FIG. 31.

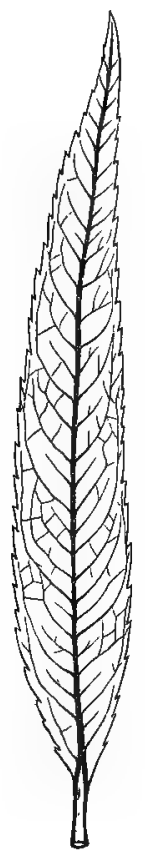

FIG. 31.-Lanceolate leaf of the Shidareyanagi (Salix babylonica).

Fr\%. 32.-Acerose and fascicled leaves of the Akamatsu.
Fra. 32.

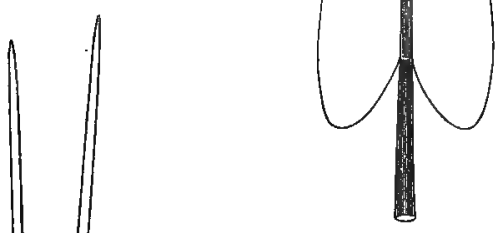

Frg. 33.-Cordate leaf of the Kōhone (Nuphar japonicum).

\section{Frg. 34.}

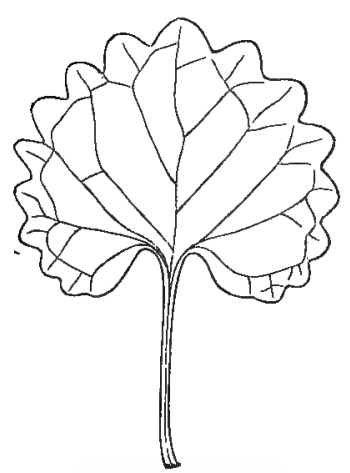

FIG. 34,-Reniform leaf of the Kakidōshi (Nepeta Glechoma). 
FIG. 35.

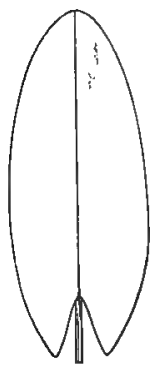

Frg. 35.-Sagittate leaf of the Unagitsukami (Polygonum strigosumt).
FIG. 36.

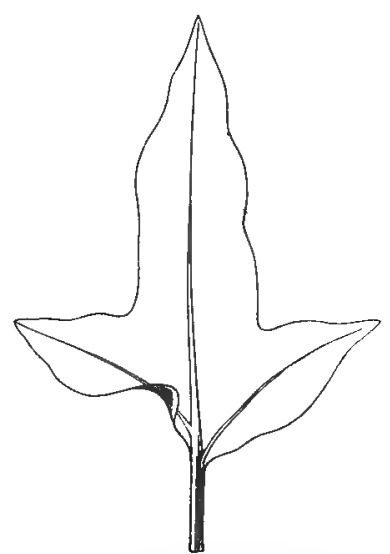

Frg. 36.-Hastate leaf of the Iwaomodaka (Polypodium tricuspe).

Unsymmetrical laminae have also several forms.

Different forms of laminae are represented in the following table.

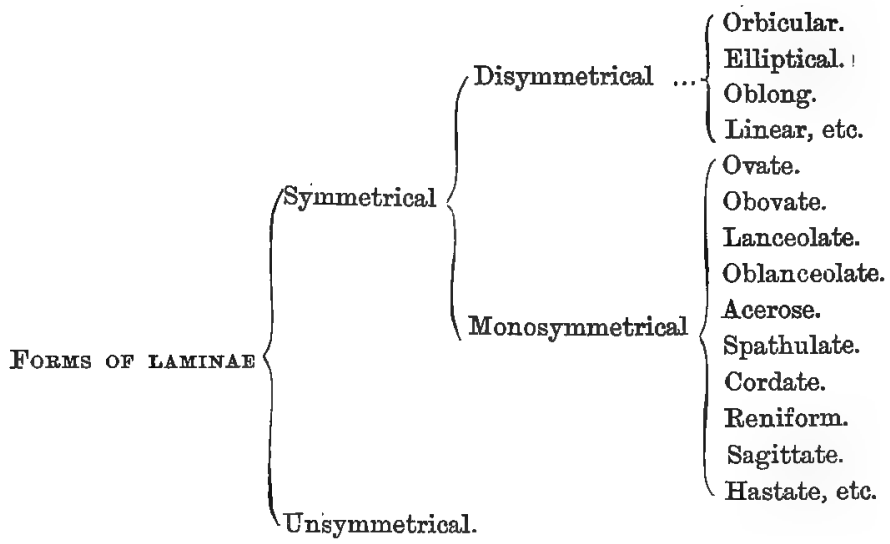




\section{MARGINS OF THE LAMINA.}

In reference to the margin, the lamina may be either without notches of any kind as in the Yudzuriha (Fig. 25) and Köhone (Fig. 33), or with notches of some kind as in the Sakura (Fig. 16) and Momiji (F'ig. 18); when without notches the lamina is said to be Entire or Even, and when with notches Uneven.

\section{Margins of laminae $\left\{\begin{array}{l}\text { Entire. } \\ \text { Uneven. }\end{array}\right.$}

Among uneven laminae, some have their margins cut into numerous small indentations, as in the Mume and Sakura (Fig. 16); some have their margins deeply cut into divisions which extend not more than half way down, as in the Budo (Fig. 15) and Zeniaoi (Malva sylvestris); some have deeper divisions which extend more than half way down, but do not reach to the midrib or the base, as in the Momiji (Fig. 18) and Yatsude; and others have still deeper divisions reaching to the midrib or the base, as in the Botan (Pronia Moutan) and Karatachi (Citrus trifoliata) (Fig. 37). When its margins are cut into small indentations, the lamina is said to be Dentate; when cut into Fig. 37.

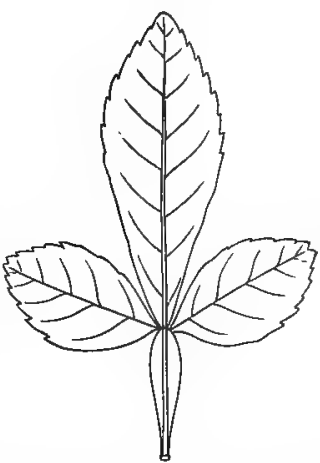

FIG. 37.-Palmately divided or compound leat of the Karatachi (Citrus trifoliata).

divisions extending not more than half way down, it is said to be Lobed; when the divisions are more than half way down, it is said to be Parted; and when the divisions reach to the midrib or the base, it is said to be Divided. 


$$
\text { Margins of LAMinaE }\left\{\begin{array}{l}
\text { Entire. } \\
\text { Uneren }\left\{\begin{array}{l}
\text { Dentate. } \\
\text { Lobed. } \\
\text { Parted. } \\
\text { Divided. }
\end{array}\right.
\end{array}\right.
$$

The apex of the lamina varies much in different leaves: thus, it is either sharp as in the Shidareyanagi (Fig. 31); rounded as in the Kirishima (Rhododendron indicum, var. obtusum) and Tabirako (Fig. 30); abruptly pointed as in the Medohagi (Lespedeza sericea) ; straight as if cut across as in the Tulip-tree; or notched as in the Katabami (Oxalis corniculata). When sharp it is said to be Acute; when rounded, Obtuse; when abruptly pointed, Mucronate; when straight as if cut across, Truncate; and when more or less notched, Emarginate.

$$
\text { APEX OF THE LAMINA }\left\{\begin{array}{l}
\text { Acute. } \\
\text { Obtuse. } \\
\text { Mucronate. } \\
\text { Truncate. } \\
\text { Emarginate. }
\end{array}\right.
$$

5. INSERTION OF 'THE LAMINA.

The lamina is inserted on the stem in different ways: in some leaves it arises immediately from the stem, as in the Doku-utsugi (Fig. 19) and Yayemugura (Fig. 29); while in others it is attached to the stem by means of the petiole or the sheath, as in the Momiji (Fig. 18) and Sakura (Fig. 16). The former kind of insertion is said to be Direct, and the latter Indivect.

$$
\text { INSERTION OF THE LAMINA }\left\{\begin{array}{l}
\text { Direct. } \\
\text { Indirect. }
\end{array}\right.
$$

Among the laminae whose insertions are direct, some have their margins near the base not at all united except at the point where they are attached to the stem, as in the 
Doku-utsugi (Fig. 19) and Yayemugura (Fig. 29); while others have prolonged basilar lobes more or less united with the stem, as in the Kaizaiku (Ammobium alatum). The direct insertion as in the former case is said to be Free, and that as in the latter Adnate.

\section{Direct Insertion $\left\{\begin{array}{l}\text { Free. } \\ \text { Adnate. }\end{array}\right.$}

Among adnate leaves, some have their basilar lobes united on the opposite side of the stem; some are opposite and have their bases cohering around the stem (Fig. 38); and others have their basilar lobes prolonged dowa the stem. In the first case, leaves are said to be Perfoliate; in the second, Connate; and in the last, Decurrent.

Among the laminae whose insertions are indirect, ordinary ones are attached to the patiole or the sheath by their baises, but others are fixed to the petiole by a point more or less within their margins, as in the Hasu (Fig. 23) and Junsai (Brasenia peltata). The indirect insertion as in the former case is said to be Basal, and that as in the latter Intramarginal. When the lamina of a leaf is intramarginally attached to the petiole, the leaf is termed Peltate.

$$
\text { INDIRECT INSERTION }\left\{\begin{array}{l}
\text { Basal. } \\
\text { Intramarginal. }
\end{array}\right.
$$

Different modes of insertion are represented in the following table.

INSERTION OF THE LAMINA $\left\{\begin{array}{l}\text { Direct }\left\{\begin{array}{l}\text { Free. } \\ \text { Adnate. }\end{array}\right. \\ \text { Indirect }\left\{\begin{array}{l}\text { Basal. } \\ \text { Intramaryinal. }\end{array}\right.\end{array}\right.$ 


\section{b. The Petiole.}

The Petiole is that portion of a leaf, which stands between the lamina and the sheath and is ustrally semicylindrical being branched or not. Not unfrequently the petiole presents foliaceous margins, as in the Yudzu (Citrus aurantium) (Fig. 47) and Nurude (Rhus semi-alata), and is then said to be Winged or Alate.

Duration of T'He Petiole.-The duration of the petiole is mostly similar with the lamina which it bears, but in a few cases it remains on the stem after its lamina falls off, as in the Aokatsura (Sabia japonica).

\section{c. The Leaf-sheath.}

The Leaf-sheath is that portion of a leaf, which stands below the petiole and embraces the stem more or less assuming a tubular or sheath-like form. It is very much developed in Grasses, Sedges, and many Umbelliferae as the Nodake (Angelica decursiva), Ashitaba (A. Kiusiana), etc.; in Grasses it is usually split in front, but in Sedges it is mostly closed.

It is often provided with two small leafy appendages. which are situated one on each side of the leaf-sheath, as in the Sakura (Fig. 16) and Noibara (Rosa multiflora). 'Those. leafy appendages are called Stipules.

Duration of Stipdles.-The duration of stipules varies. in different leaves: in some leaves, as those of the Molkuren and Sakura (Fig. 39), they fall off very soon; while in others, as those of the Noibara and Yendo (Pisum sativum), they remain attached as long as the laminæ. The stipules of the former kind are said to be Deciduous, and those of the latter Persistent. 
2. IRRANGEMEN' OF LEAVES ON THE S'IEMI OR PHYLLOTAXIS.

The various modes in which leaves are arranged on the stem are called Phyllotaxis.

Leaves are produced either singly at a node, as in the Mume and Sakura (Fig. 39), or two or more at the same node in the form of a whorl, as in the Aokiba (Aucuba japonica) (Fig. 41) and Yayemugura ; the formre kind of phyllotaxis is said to be Scattered or Unimerous, and the latter Polymerous.

\section{ARRANGEMENT OF LEAVES $\left\{\begin{array}{l}\text { Unimerous. } \\ \text { Polymerous. }\end{array}\right.$}

The scattered leaves are ordinarily produced on the stem with elongated internodes, as in the Mume and Sakura (Fig. 39); but in some cases they are developed on a

FIG. 39.

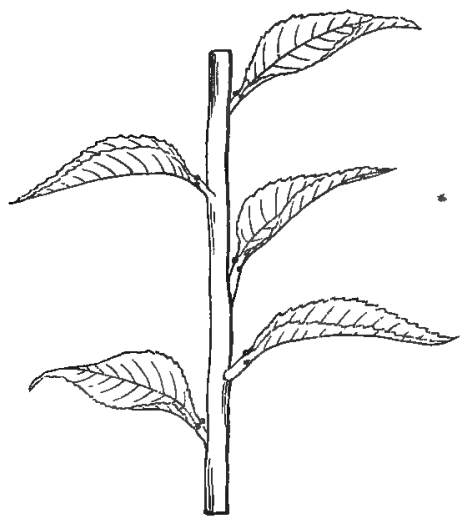

FIG. 39.--Shoot of the Sakura with alternate leaves.
FIG. 40.

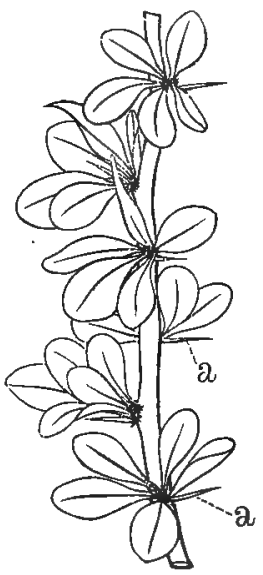

FIG. 40.-Shoot of the Megi (Berberis Thunbergii), with fascicled leaves.

a Spine. 
branch of which the internodes do not elongate, so that all the leaves of that branch are brought close together, as in the Akamatsu (Fig. 32) and Megi (Berberis Thunbergii), (Fig. 40). The leaves of the former, arrangement are said to be Alternate, and those of the latter Fascicled or Spuriously Verticillate.

\section{SCATTERED LEAVES $\left\{\begin{array}{l}\text { Alternate. } \\ \text { Fascicled. }\end{array}\right.$}

There are also two varieties among polymerous leaves: in one case, two leaves are produced at a node on opposite sides of the stem, as in the Nadeshiko (Dianthus chinensis) and Aokiba (Fig. 41); and in the other, three or more leaves are so produced at a node that the distance between any two adjacent leaves is equal, as in the Kyōchikutō (Nerium odorum) (Fig. 42) and Yayemugura.

Frg. 41.

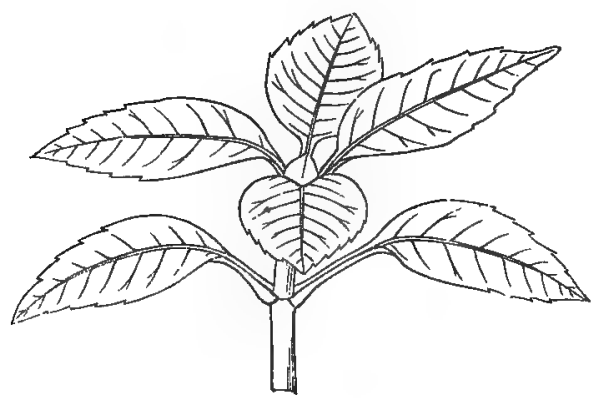

FrG. 41.-Shoot of the Aolriba ( Aucuba japonica), with opposite leaves.

The leaves of the former arrangement are said to be Opposite, and those of the latter Verticillate. 
FIG 42.

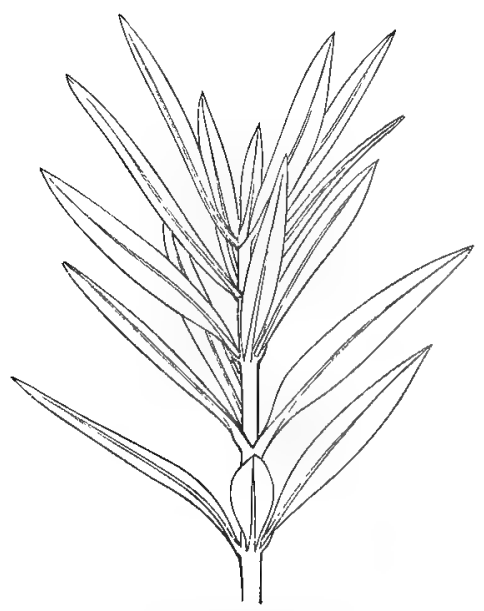

F'IG. 42.- Shoot of the Kyōehikutō

(Nerium odorum), with verticillate leaves.

Different kinds of the arrangement of leaves are represented in the following table.

$$
\text { ArRANGEMENT OF LEAVES } \begin{cases}\text { Scattered } & \left\{\begin{array}{l}
\text { Alternate. } \\
\text { Fascicled. }
\end{array}\right. \\
\text { Polymerous } & \left\{\begin{array}{l}
\text { Opposite. } \\
\text { Verticillate. }
\end{array}\right.\end{cases}
$$

\section{ANGULAR DIVERGENCE OF LEAVES.}

The lateral distance between the bases of any two adjacent leaves is called the Angular Divergence, and it is expressed in fractions. In different individuals of the same species of plants the angular divergence is usually constant.

As the opposite leaves are exactly situated on opposite sides of the stem (Fig. 41), the angular divergence must be just one-half of the circumference.

In most cases the opposite leaves at any two adjacent nodes alternate (Fig. 41 and 43), so that the leaves at the first node lie opposite to or 
below the leaves at the third node, and the leaves at the second node lie opposite to those at the fourth node, and so forth; hence, in this case there are found four longitudinal series of leaves placed up and down.

FIa. 43.

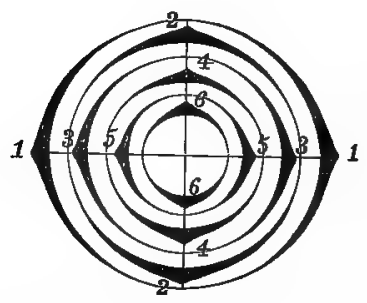

Fia. 43.-Diagram of a stem with opposite leaves ; $1,2,3,4,5,6$, the successive whorls. (Prantl.)

These longitudinal series of leaves are called Orthostichies or Vertical Ranks.

In the whorl consisting of three leaves (Fig. 42), the anglar divergence must be one-third of the circumference, as the distance between any two adjacent leaves is equal. In this case also, the leaves at any two adjacent nodes alternate, so that the leaves. at the first node lie opposite to the leaves at the third node, and so on; hence, there will be six longitudinal series of leaves placed up and down, or six vertical ranks of leaves.

If a whorl consists of four leaves, the angular divergence will be onefourth of the circumference and there will be eight vertical ranks of leaves.

In the other kinds of verticillate leaves also, the angular divergence is usually found to be a fraction that has one for its numerator and the number of leaves at one node for its denominator, and the number of vertical ranks is just twice the number of leaves at one node.

Fig. 44.

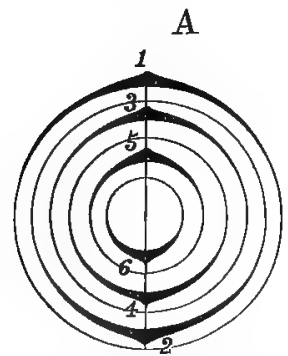

FIG. 44.-Diagram of a stem bearing alternate leaves with a divergence of $\frac{1}{2} ; 1,2,3,4,5,6$, the successive leaves.

(Prantl.)
FrG. 45.

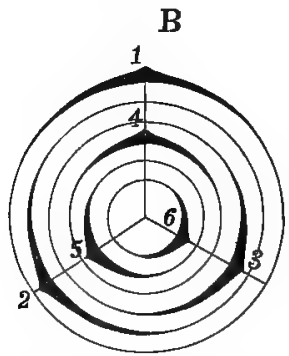

Fig. 45.-Diagram of a stem bearing alternate leaves with a divergence of $\frac{1}{8}$.

(Prantl.) 
In the simplest case of alternate leaves (Fig..44), the leaf at the second node is above and exactly opposite to the leaf at the first node, and that at the third node is disposed vertically over the leaf at the first node. Hence, the angular divergence is here one-half of the circumierence, and there are two vertical ranks of leaves. Now if we connect the bases of the leaves with $\dot{a}$ line from below upwards always in the same direction, a spiral will be drawn. As this spiral passes through the bases of leaves in the order of their development, it is called the Genetic Spiral. By the fraction $\frac{1}{2}$, not only the angular divergence is expressed, but also the numerator 1 denotes that there is one turn of the genetic spiral from one leaf to another which is disposed directly above, and the denominator 2 denotes that there are two vertical ranks.

In the next simpler case of alternate leares, the fourth leaf that is one at the. fourth node is placed vertically over the first leaf (Fig. 45); so that

FIg. 46.

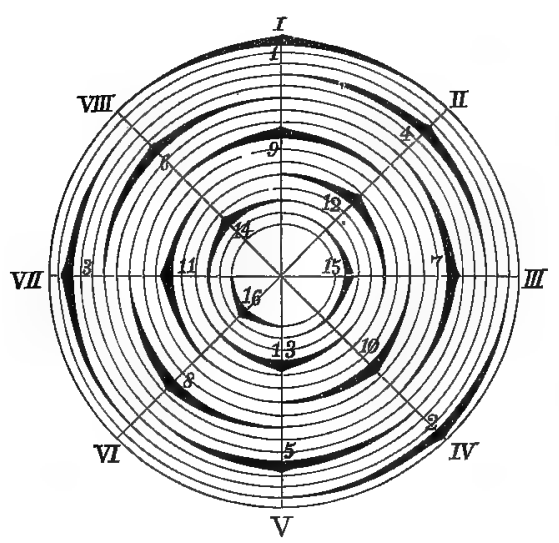

FIG. 46.-Diagram of a stem bearing alternate leaves with a divergence of $\frac{\text { s. }}{8}$; I, II, III, etc., the vertical lines. (Sachs.)

the angular divergence is one-third of the circumference, vertical ranks are three, and the genetic spiral makes one turn round the stem from the first leaf to the fourth.

In the next case, the sixth leaf is placed directly above the first, so that the angular divergence is two-fifths, there being five vertical ranks and the genetic spiral making two turns. 
In the next case, the ninth leaf is placed directly above the first, so that the angular divergence is three-eighths there being eight vertical ranks and three turns of the spiral.

In the next case, the angular divergence is five-thirteenths, the fourteenth leaf being placed vertically over the first; there are thirteen vertical ranks and five turns of the spiral.

Then follow such divergences as $\frac{8}{21}$, $\frac{18}{34}$, etc. If the preceeding fractions representing angular divergences are carefully observed, it will be seen that a certain relation exists between them; thus the sum of any two preceeding numerators is the numerator of the next succeeding fraction, and the same is true of the denominators. Therefore, the series of Iractions representing the angular divergence may be expressed by the continued fraction,

$$
\begin{aligned}
& \frac{1}{2}+\frac{1}{1}+\frac{1}{1}+\frac{1}{1} \text {, etc. } \\
& \frac{1}{2} \text { (simplest angular divergence). } \\
& \frac{1}{2}+1=\frac{1}{3} \text { (next angular divergence). } \\
& \frac{1}{2}+\frac{1}{1}+1=\frac{1}{2}+\frac{1}{2}=\frac{1}{5}=\frac{2}{5} \text { (next angular divergence). }
\end{aligned}
$$

There are still other divergences, but not common, as $\frac{1}{4}, \frac{2}{7}, \frac{2}{9}$, etc.

\section{KINDS OF FOLIAGE LEAVES IN REFERENCE TO THEIR COMPOSITION.}

Some foliage leaves have only one lamina and never more than one articulation at the base, as in the Mume and Sakura (Fig. 16); while others have two or more laminae, as in the Fuji (Wistaria chinensis) (Fig. 48) and Akebi (Akebia quinata) (Fig. 49), or one lamina and two articulations, as in the Yudzu (Fig. 47) and Megi. Those of the former kind are called Simple Leaves and those of the latter Compound. 
KINDS OF FOLTAGE LEAVES IN REFERENCE Simple Leaves.

- TO THEIR COMPOSITION

$\{$ Compound Leaves.

Those compound leaves with FIG. 47. one lamina, as in the Yudzu (Fig. 47) and Megi, are said to be Unifoliolate, and those with two or more laminae, as in the Fuji (Fig. 48) and Akebi (Fig. 49), are said to be Multifoliolate.

CompoUnd LEAvES $\left\{\begin{array}{l}\text { Unifoliolate. } \\ \text { Multifoliolate. }\end{array}\right.$

In compound leaves, their laminae are called Leaflets, the stallks of leaflets Petiolules, and the stipules of leaflets Stipels.

Frg. 48.

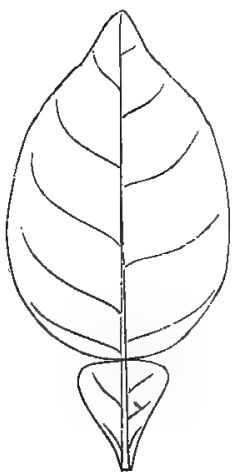

Frg. 47.-Unifoliolate compound learî of the Yudzu (Citrus aurantizm).

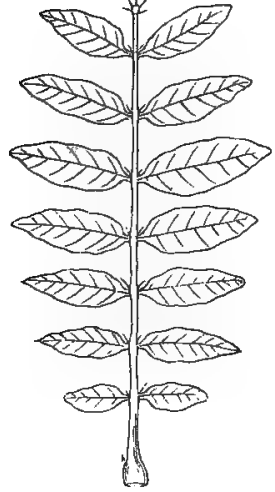

\section{FIG. 49.}

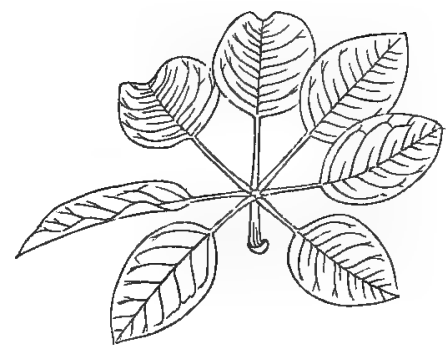

Fia. 48.-Pinnately compound leaf of the Fuji. (Wistaria chinensis).

FIg. 49.-Palmately compound leafof the Akebi (Akebia quinata). 
Some multifoliolate compound leaves have their leaflets arranged laterally on a common petiole, as in the Fuji (Fig. 48) and Yendō, while others have their leaflets arranged on the top of a common petiole, as in the Akebi (Fig. 49) and Tochinoki (Aesculus turbinata).

Those of the former kind are called Pinnately Compound Leaves and those of the latter Palmately Compound.

\section{Moltifoliolate compound $\{$ Pinnately Compound Leaves. LEAVES $\{$ Palmately Compound Leaves.}

All the kinds of leaves in reference to their composition are represented in the following table.

KINDS OF LEATES

IN REFERENOE

TO THEIR

COMPOSTTION
Simple Leaves.

Compound
Leaves......... $\left\{\begin{array}{c}\text { Unifoliolate Compound Leaves. } \\ \text { Multifoliolate Com- } \\ \text { pound Leaves....... }\end{array} \begin{array}{r}\text { Pinnately Com- } \\ \text { pound Leaves. } \\ \text { Palmately Com- } \\ \text { pound Leaves. }\end{array}\right.$

\section{B. MODIFIED LEAVES.}

Modified Leaves are those, which are either changed to perform some particular functions, or only retrograded from normal ones.

Some of the modified leaves are related either directly or indirectly to the nutrition of the plant to which they belong, as the insect-catching leaves of the Mūsengoke (Drosera rotundifolia) (Fig. 50) or the spines of the Megi (Fig. 40); while others are related either directly or indirectly to reproduction, as the fruit-bearing leaves of the Nokishinobu (Polypodium lineare) (Fig. 51) or the floral leaves of the Sakura (Fig. 55). Those of the former kind are said to be Nutritive or Vegetative, and those of the latter Reproductive.

$$
\text { MODIFIED LEAVES }\left\{\begin{array}{l}
\text { Nutritive. } \\
\text { Reproductive. }
\end{array}\right.
$$


F'Ia. 50.

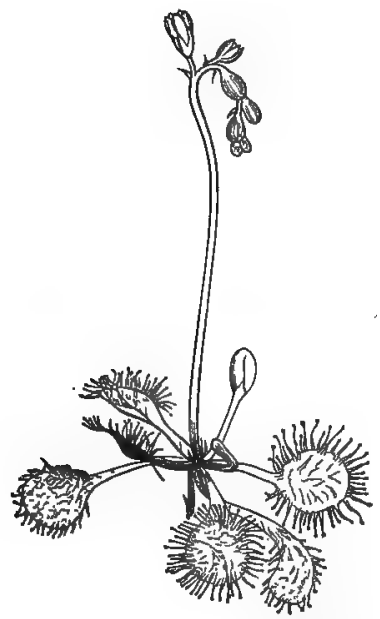

FIG. 50.-Mōsengoke (Drosera roturidifolia).
FIG. 51.

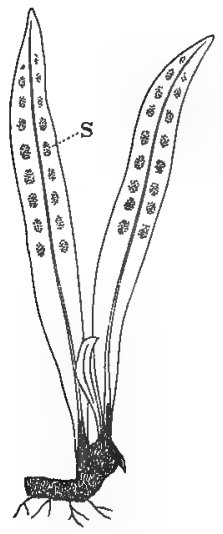

FrG. 51.-Nokishinobu (Polypodium lineare).

S. Clusters of spore-cases.

1. NUTRITIVE MODIFIED LEAVES.

There are many kinds of nutritive modified leaves: some are hard and needleshaped, as the spines of the Megi (Fig. 40) and Hebinoboradzu (Berberis vulgaris); some are thread-like and capable of coiling spirally, as the climbing organs of the Yendo and Shiode (Fig. 52); some are small and scaly, as the subterranean leaves of the Oniyuri (Fig. 12)
FIG. 52.

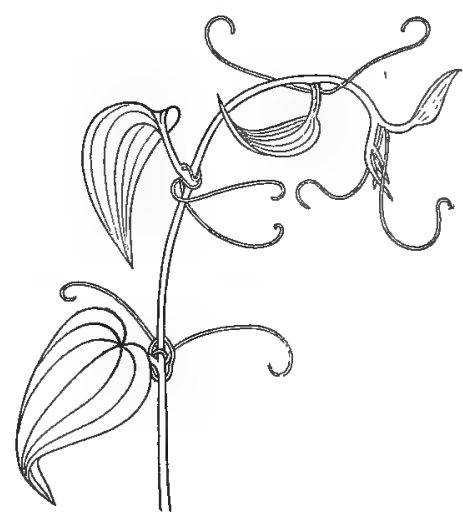

FIG. 5\%.-Shoot of the Shiode (Smilax herbacea) with tendrils. 
and Jagataraimo (Fig. 14); and others are either flattened or bag-shaped, capable of catching insects, as the flattened leaves of the Mōsengoke (Fig. 50) or the bag-shaped leaflets of the Tanukimo (Utricularia vulgaris).

Those sharp-pointed leaves or parts of leaves are called Spines ; those thread-like leaves or parts of leaves Tendrils; those scaly ones Cataphyllary Leaves; and those insectcatchers Insectivorous Leaves. (See Fig. 17.)

Not only leaves, but branches also are transformed into spines, as in the Saikachi (Gleditschia japonica) and Nashi (Pyrus sinensis), and into tendrils, as in the Budo (Fig. 15) and Tsuta (Vitis inconstans). These modified branches may be readily distinguished from modified leaves by their point of origin (modified branches arise from axils of leaves or are direct continuations of stems).

$$
\text { NUTRLTIVE MODIFIED LEAVES }\left\{\begin{array}{l}
\text { Spines. } \\
\text { Tendrils. } \\
\text { Cataphyllary Leaves. } \\
\text { Insectivorons Leaves. }
\end{array}\right.
$$

2. REPRODUCTIVE MODIFIEDD LEAVES.

There are also several kinds of reproductive modified leaves: in one case, numerous ones are clustered on a branch, of which the internodes are seldom developed, to subserve reproduction; some ones are situated below the above mentioned clusters to protect or help them, as the flowercovering-leaves of the Tennanshō (Ariscema japonicum) (Fig. 53) and Ayame; and others are scattered and bear minute fructifications, as in the Warabi (Pteris aquilina) and Nokishinobu (Fig. 51).

The group of numerous leaves modified to subserve reproduction is called a Flower, and its constituents are 
FIศ. 53.

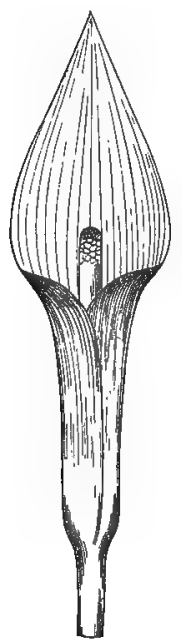

Frg. 53.-Inflorescence ố the Tennansho (Arisaema japonicum) enclosed in a scattered bract. termed Floral Leaves; those situated below a flower or flowers Hypsophyllary Leaves or Bracts; and those bearing minute fructifications Spore-bearing Leaves. (See Fig. 17.)

\section{Reproductive Floral Leaves. \\ MODIFIED
LEAVES $\quad\left\{\begin{array}{l}\text { Hypsophyllary Leaves. } \\ \text { Spore-bearing Leaves. }\end{array}\right.$}

FLORAL LEAVES.

The F'loral Leaves are usually clustered into a group which is termed a Flower.

\section{PARTS OF THE FLOWER.}

A fully organized flower, as in the Kabura (Fig. 54) and Sakura (Fig. 55), consists of four different series of floral leaves: the outermost whorl called the Calyx is composed of flat-

Fig. 54.

FIG. 55.

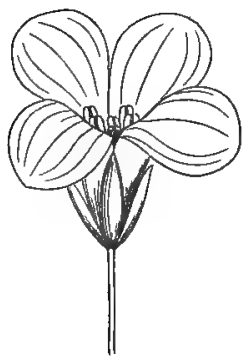

Fra. 54.-Flower of the Kabura (Brassica campest'is).

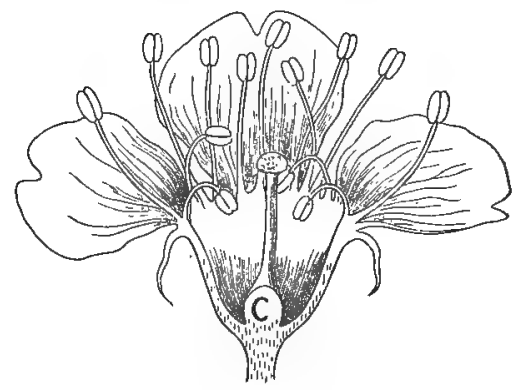

Fra. 55.-Flower of the Sakura cut open. 
tened leafy organs; the next whorl within the calyx called the Corolla is also composed of flattened leafy organs; the third whorl within the corolla called the Andrecium consists of more or less thread-like organs; and the fourth series within the androecium called the Gynocium occupies the centre of the flower and consists of more or less sac-like organs.

As the calyx and corolla are especially designed for the protection of the organs within, they are called Protective Organs or Floral Envelopes; while the androecium and gynociurn are called Essential Organs, as they are indispensable for the main purpose of the flower.

$$
\text { PARTS OF THE FLOWER }\left\{\begin{array}{l}
\text { Protective Organs }\left\{\begin{array} { l } 
{ \text { Calyz. } } \\
{ \text { Corolla. } } \\
{ \text { Essential Organs } }
\end{array} \left\{\begin{array}{l}
\text { Andrcecium. } \\
\text { Gynœcium. }
\end{array}\right.\right.
\end{array}\right.
$$

\section{THE CALYX.}

The Calyx is the outermost envelope of the flower and it is composed of flattened usually green organs called Sepals.

Ddration of the Calyx.-The duration of the calyx varies in different plants: in some plants, as the Keshi (Papaver somniferum) and Kusanoo (Chelidonium majus), it falls off when the flower expands; in other plants, as the Kabura and Mume, it falls off with or after the corolla; and in others, as the Kaki (Diospyros Kaki) and Hodzuki (Physalis Alkekengi), it remains after the flowering is over. The calyx of the first kind is said to be Caducous or Fugacious; that of the second kind Deciduous; and that of the third kind Persistent.

DuRation OF THE CALYX $\left\{\begin{array}{l}\text { Caducous. } \\ \text { Deciduous. } \\ \text { Persistent. }\end{array}\right.$ 
KINDS OF THE CALYX.-The calyx is composed of either distinct sepals, as in the Kabura (Fig. 54) and Kimpōge (Ranunculus acris); or more or less united sepals, as in the Mume and Saliura (Fig. 55). In the former case, it is said to be Dialysepalous or Polysepalous; and in the latter, Gamosepalous or Monosepalous.

\section{KINDS OF THE CALYX $\left\{\begin{array}{l}\text { Dialysepalous Calyx. } \\ \text { Gamosepalous Calyx. }\end{array}\right.$}

The dialysepalous calyx may be composed either of sepals of equal size and like form, as in the Kabura (Fig. 54) and Kimpōge; or of sepals of unequal size FIG. 56. and unlike form, as in the Torikabuto (Aconitum Fischeri) and Sumire (Viola Patrinii) (Fig. 56). In the former case, it is said to be Regular, and in the latter Irregular.

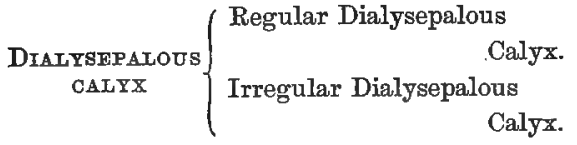

FIG. 57.

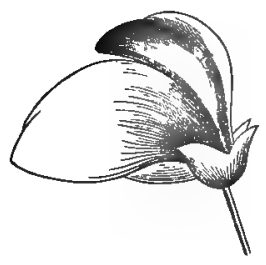

Fra. 57.-Flower of the Fuji.
The gamosepalous calyx may

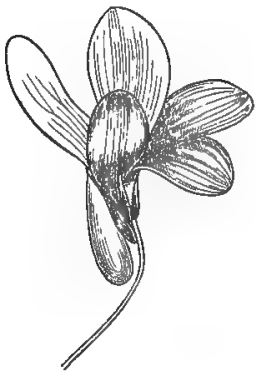

Fig. 56.-Flower of the Sumire

(Viola Patrinii). be also composed either of sepals of equal size and like form, as in the Mume and Sakura (Fig. 55); or of sepals of unequal size and unlike form, as in the Fuji (Fig. 57) and Odorikoso (Lamium album) (Fig. 59). In the former case, it is also called Regular, and in the latter Irregular.

Gamosepalous CALYX $\left\{\begin{array}{l}\text { Regular Gamosepalous Calyx. } \\ \text { Irregular Gamosepalous Calyx. }\end{array}\right.$ 
All the kinds of calyx are represented in the following table.

$$
\operatorname{CALYX}\left\{\begin{array}{l}
\text { Dialysepalous Calyz }\left\{\begin{array}{l}
\text { Regular Dialysepalous Calyz. } \\
\text { Irregular Dialysepalous Calyz. }
\end{array}\right. \\
\text { Gamosepalous, Calyz }\left\{\begin{array}{l}
\text { Regular Gamosepalous Calyx. } \\
\text { Irregular Gamosepalous Calyx. }
\end{array}\right.
\end{array}\right.
$$

PARTs.-Although the sepals are modified leaves, yet commonly they are not provided with those portions corres-

FIG. 58.

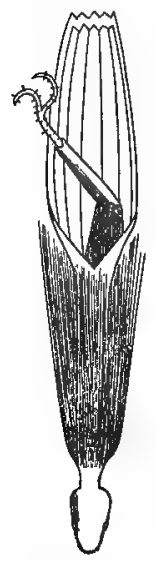

Frg. 58.-Flower of the Tampopo ponding to the petiole and sheath. In a gamosepalous calyx, the part where the sepals are united is called the Tube, the free border the Limb, and the opening of the tube the Throat (Fig. 59). Sometimes the limb of the calyx is developed in the form of scales or hairs called Pappus, as in the Tampopo (Taraxacum officinale) (Fig. 58) and Shion (Aster tataricus).

\section{THE COROLLA.}

The Corolla is the inner floral envelope situated within the calyx and it is composed of flattened usually ('Taraxacum officinale). colored organs called Petals.

DURATION OF THE COROLLA.-The duration of the corolla, like that of the calyx, varies in different plants. It is either Caducous, as in the Budo and Yabukarashi (Vitis pentaphylla), Deciduous, as in the Mume and Keshi, or Persistent, as in the Dolru-utsugi.

DURation OF THE COROLLA $\left\{\begin{array}{l}\text { Caducous. } \\ \text { Deciduous. } \\ \text { Persistent. }\end{array}\right.$ 
KINDS OF THE CoRolla.--The corolla is also composed either of separate patals, as in the Kimpogge and Sakikura (Fig. 55); or of more or less united petals, as in the Asagao (Fig. 9) and Odorikoso (Fig. 59). In the former case, it is called Dialypetalous or Polypetalous, and in the latter Gamopetalous or Monopetalous.

$$
\text { KINDS OF THE COROLLA }\left\{\begin{array}{l}
\text { Dialypetalous Corolla. } \\
\text { Gamopetalous Corolla. }
\end{array}\right.
$$

The dialypetalous corolla is again composed either of petals of equal size and like form, as in the Kimpüge and Sakura (Fig. 55); or of patals of unequal size and unlike form, as in the Sumire (Fig. 56) and Fuji (Fig. 57). In the former case, it is called Regular as in the calyx, and in the latter Irregular.

Diatypetalods corolda $\left\{\begin{array}{l}\text { Regular Dialypetalous Corolla. } \\ \text { Irregular Dialypetalous Corolla. }\end{array}\right.$

The gamopetalous corolla is also either Regular as in the Asagao (Fig. 9) and Hōdzuki, or Irregular, as in the Odorikoso (Fig. 59) and Kiri (Paulownia imperialis).

$\underset{\text { Gorolda }}{\text { Gamopetadods }}\left\{\begin{array}{r}\text { Regular Gamopetalous } \\ \text { Corolla. } \\ \text { Irregular Gamopetalous } \\ \text { Corolla. }\end{array}\right.$

All the kinds of corolla are represented in the following table.

FIG. 59.

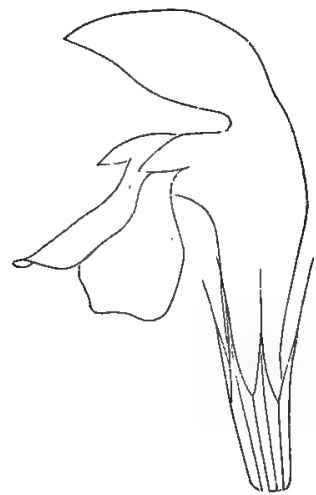

Fia. 59.-FIower of the Odorikosō (Lamium album). 
CoRoLLA $\begin{cases}\text { Dialypetalous Corolla } & \begin{array}{l}\text { Regular Dialypetalous Corolla. } \\ \text { Irregular Dialypetalous Corolla. }\end{array} \\ \text { Gamopetalous Corolla } & \left\{\begin{array}{l}\text { Regular Gamopetalous Corolla. } \\ \text { Irregular Grmopetalous Corolla. }\end{array}\right.\end{cases}$

PARTs.-A fully developed petal consists of an expanded

Fig. 60.

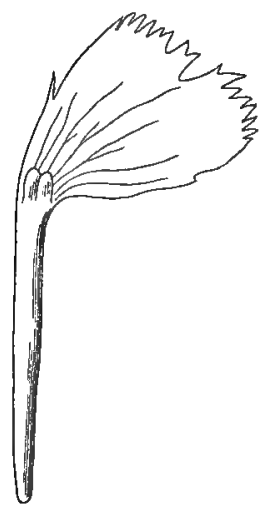

Fra. 60.-Petal of the Gampi

(Lychnis grandifora). upper portion corresponding to the lamina of a leaf and $a$ narrow stalk-like portion which is amalogous to the petiole, as in the Nadeshiko and Gampi (Lychnis grandiflora) (Fig. 60). The expanded portion is called the $\operatorname{Limb}$, and the petiolar portion the Claw. In a gamopetalous corolla, the part where the petals are united is also called the Tube, the free border the Limb, and the orifice of the tube the Throat (Fig. 59).

\section{THE ANDRCEIUM.}

The Androcium is the outer series of the essential organs situated within the corolla, and it is composed of one or more thread-like organs called Stamens.

Parts of THE STAMEN.--A fully organized stamen consists of a bag-like portion, which is analogous to the lamina, and a slender stalk, which is the representative of the petiole. The bag-like portion is called the Anther and the stalk the Filament (Fig. 65 and 67). The anther is usually divided into two equal halves which are separated perpendicularly by a central portion corresponding to the midrib. Each half is called an Anther-lobe and it has one or two cavities containing minute granules; and the central portion is 
termed the Connective. The cavity of the anther is called the Anther-cell, and its granular contents are collectively termed the Pollen.

In a few cases, the anther is provided with only one lobe.

$$
\text { Parts of the Stamen }\left\{\begin{array}{l}
\text { Anther }\left\{\begin{array}{l}
\text { Anther-lobes-Pollen. } \\
\text { Connective. }
\end{array}\right. \\
\text { Filament. }
\end{array}\right.
$$

DURation of the ANDRgclum.-Most stamens fall off when their anthers discharge their contained pollen, as in the Keshi and Kabura, but in rare cases they remain after the flowering is over, as in the Hotarubukuro (Campanula punctata) and Fūrinsô (C. Medium). In the former case the androcium is said to be deciduous, and in the latter Persistent.

$$
\text { Duration of the andrøarum }\left\{\begin{array}{l}
\text { Deciduous. } \\
\text { Persistent. }
\end{array}\right.
$$

Kinds of the AndreCIUM.-The androcium is composed either of separate stamens, as in the Kimpogge and

FIg. 61.

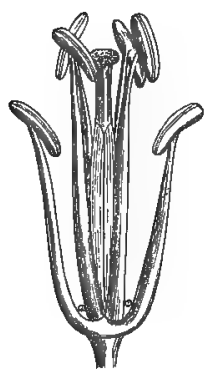

FIQ. 61.-T'etradynamous androecinm of the Kabura.
FIG. 62.

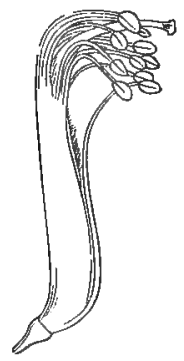

FIG. 62.-Diadelphous androecium of the Fruji.

Kabura (Fig. 61), or of more or less united stamens, as in the Fuji (Fig. 62) and Mukuge (Hibiscus syriacus). In 
the former case, it is said to be Apostemonous, and in the latter, Synistemonous.

\section{KINDS OF THE ANDR@CIUM $\left\{\begin{array}{l}\text { Apostemonous Andrœeium. } \\ \text { Syastemonous Androcium. }\end{array}\right.$}

FIG. 63.

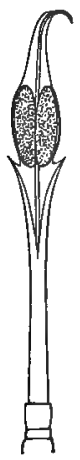

Fra. 63.-Simple apostemonous androecium of the Myogga

(Zingiber Mioga).

The apostemonous androcium may consist either of but one fertile stamen, as in the Myōga (Zingiber Mioga) (Fig. 63) and Dandoku (Canna indica), or of two or more stamens, as in the Kitsunenomago (Justicia procumbens) and Kabura (Fig. 61). In the former case it is said to be Simple, and in the latter Multiple.

Apostemonods
ANDRGCid M $\left\{\begin{array}{c}\text { Simple Apostemonous } \\ \text { Androcium. } \\ \text { Multiple Apostemonous } \\ \text { Androcium. }\end{array}\right.$

Fig. 64.

The multiple apostemonous andrœcium may be composed either of those stamens which are all of the same length and like form, as in the Mayumi (Euonymus europaus, var. Hamilitonianus) (F'ig. 64) and Ayame (see Fig. 69); or of those which are of different length or unlike form, as in the Kabura (Fig. 61) and Tsuyukusa (Com-

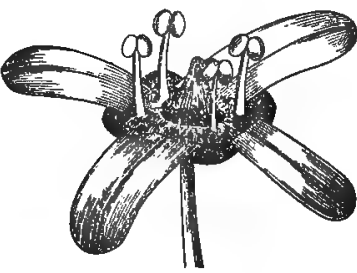

Fia. 64.-Flower of the Mayumi (Euonymus europreus, var. Hami(itonianus), showing the regular inultiple apostemonous androocium.

melina communis). In the former case it is said to be Regular, and in the latter Irregular.

Mult. Apost. Andr. $\left\{\begin{array}{l}\text { Reg. Mult. Apost. Andr. } \\ \text { Irreg. Mult. Apost. Andr. }\end{array}\right.$ 
The irregular multiple apostemonous androcium may be composed either of such unequal stamens as follow no definite rule, or of those arranged in a definite manner. In the latter case there are two important varieties : in one kind there are six stamens of which four are longer than the remaining two, as in the Kabura (Fig. 61) and Dailion; and in the other there are four stamens of which two are long and two short, as in the Odorikosō and Sagigoke (Mlazus rugosus, var. macranthus) (Fig. 93). The androcium of the former sort is said to be I'etradynamous, and that of the latter Didynamous.

The synstemonous androcium may be composed either of those stamens which are united into one body by means of their anthers or their filaments, as in the Tampopo (Fig. 58) and Mukuge; or of those which are united into two or more bodies by their filaments, as in the Fuji (Fig. 62) and Otogiriso (Hypericum erectum). The synstemonous androecium of the former kind is said to be Complete, and that of the latter Incomplete.

STNSTEMONOUS ANDRECIUM $\left\{\begin{array}{l}\text { Complete Synstemonous Androecium. } \\ \text { Incomplete Synstemonous Andrœcium. }\end{array}\right.$

A complete synstemonous andrœcium consisting of stamens which are united into one body by means of their anthers, as in the Tampopo (Fig. 58) and Shion, is said to be Syngenesious; and that composed of stamen which are united into one body by their filaments, as in the Mukuge and Zeniwi, is said to be Monadelphous.

An incomplete synstemonous androecium consisting of stamens which are united into two separate bundles, as in the Fuji (Fig. 62) and Yendo, is said to be Diadelphous; that composed of stamens in three bundles, as in the Otogiriso and Midzuotogiri (Hypericum virginicum), is said to be Triadelphous; and that consisting of stamens in four or more bundles, as in the T'omoyeso (Hypericum Ascyron) and Kinshibai ( $H$. patulum), is said to be Polyadelphous.

All the kinds of androecium are represented in the following table. 


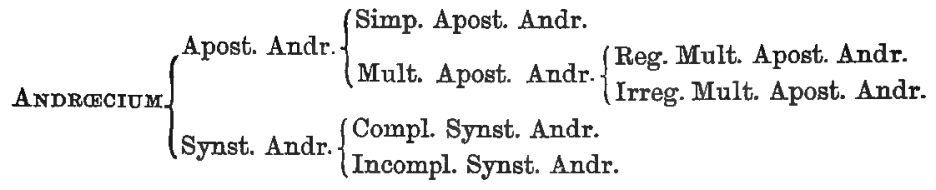

\section{THE ANTHER.}

AtTachment of the Anther to the Fllament.The attachment of the anther varies in different plants: in some plants, as the Magnolia (Fig. 65), the anther is attached on its back throughout its whole length to the filament; in some plants, as the Hebinoboradzu (Fig. 66) and all species of Carex, it is attached to the

Fia. 65.

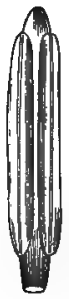

FIG. 65.-Stamen of the Mokuren

(Magnolia obovata), with adnate anther.
Fig. 66.

Fig. 67.

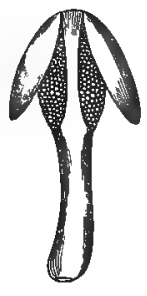

Fra. 66.-Stamen of the Hebinoboradzu (Berberis vulgaris), with innate anther.

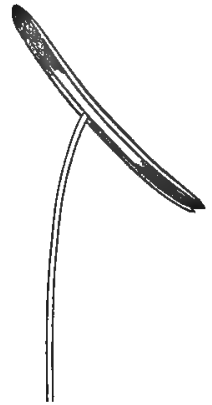

FIG. 67.-Stamen of the Oniyuri with versatile anther.

filament by its base, and its anther-lobes are mostly disposed oppositely; and in some plants, as the Oniyuri (Fig. 67) and Yamayuri (Lilium auratum), it is only attached by a point near its centre to the tip of the filament. When attached as in the first case, the anther is said to be Adnate; that attached as in the second case, Innate; and that as in the third case, Versatile. 
AtTACHMENT OF THE ANTHER $\left\{\begin{array}{l}\text { Adnate. } \\ \text { Innate. } \\ \text { Versatile. }\end{array}\right.$

Direction of the ANTHER.-The face of the anther is usually turned inwards towards the gynœecium, as in the Fra. 68.

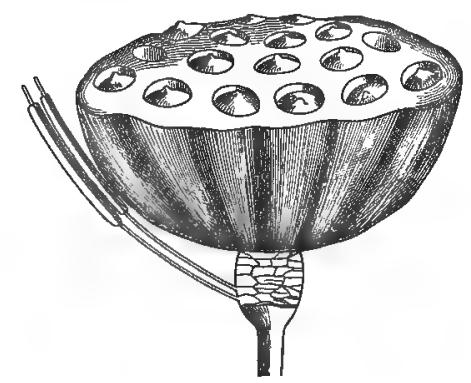

Fig. 68.-Introrse anthers of the Hasu.

F'IA. 69.

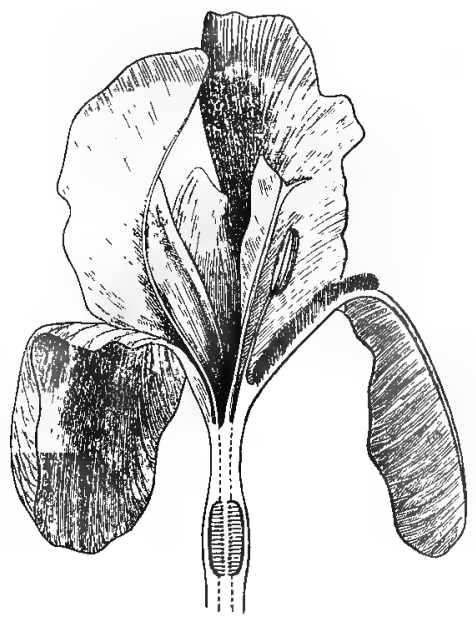

FIG. 69.-Flower of Iris pumila, with front portion and half of one petaloid style-lobe and stigma cut away, showing the ovary and a stamen with extrorse anther. (Gray.) 
Hasu (Fig. 68), but sometimes the face is turned outwards towards the floral envelopes, as in the Ayame (see Fig. 69). When turned inwards the anther is said to be Introrse; and when turned outwards it is said to be Extrorse.

$$
\text { DIRECTION OF THE ANTHER }\left\{\begin{array}{l}
\text { Introrse. } \\
\text { Extrorse. }
\end{array}\right.
$$

DeHiscence OF THE ANTHER.-The act of discharging its contained pollen is called the Dehiscence of the Anther. This dehiscence takes place in different ways : in the commonest case each anther-lobe opens longitudinally, as in the Mokuren (Fig. 65) and Hasu (Fig. 68); in some cases it. splits transversely, as in the Hinjimo (Lemna trisulca)

FIG. 70.

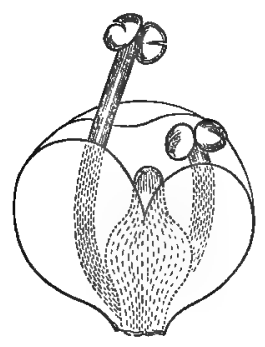

Fig. 71.

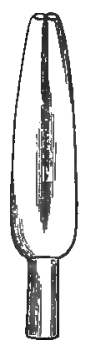

FIG. 70.-Flower of the Hinjimo Fig. 71.-Stamen of the Nasubi (Lemna trisulca) (Solanum Melongena)

with anthers opening transversely. with the anther opening by pores.

(Fig. 70); in some it opens by a hole or holes, as in the Nasubi (Solanum Melongena) (Fig. 71) and Tsutsuji (Rhododendron indicum); and in others the whole or portions of its face open like trap-doors, as in the Hebinoboradzu (Fig. 66) and all species of Lindera. The first kind of dehiscence is said to be Longitudinal, the second kind Transverse, the third kind Porous, and the last Valvular. 


$$
\text { DEHISCENCE OF THE ANTHER }\left\{\begin{array}{l}
\text { Longitudinal. } \\
\text { Transverse. } \\
\text { Porous. } \\
\text { Valvular. }
\end{array}\right.
$$

\section{THE GYNCECIUM.}

The Gynœcium is the inner series of the essential organs occupying the centre of the flower, and it is composed of one or more usually sac-like organs called Carpels. Although the carpels are mostly sac-like as in the Mume and Sakura, yet in a few cases they are open and scale-like as in the species of Pinus and they are consequently called Open or Gymnospermous Carpels. (See Fig. 127.)

PARTS OF THE CARPEL.-The ordinary uncombined carpel is made up of the lamina of a leaf, both halves of which are incurved lengthwise and united by their margins. rhus a flask-shaped organ is formed: its inflated lower portion is called the Ovary; its prolonged neck-like portion, the Style; and its usually dilated rough apex, tho Stigma (Fig. 55). The cavity of the ovary is termed its Cell, the line formed by the union of the leaf-margins the Inner or Ventral Suture, and the line corresponding to the midrib of the leaf the Outer or Dorsal Suture.

Usually the interior surface of the inner suture projects more or less and bears one or more minute bodies; the projecting portion is called the Placenta, and the minute bodies, which become Seeds when fully ripe, are called Ovules.

As the ovary and stigma are the essential parts of the carpel they are always present, but sometimes the style is wanting.

Parts of the CARPEL $\left\{\begin{array}{l}\text { Ovary-Ovule. } \\ \text { Style. } \\ \text { Stigma. }\end{array}\right.$ 
Duration of the Gyn@cidm.-The gynoecium does not fall off as the other parts of the flower commonly do, but it becomes the Fruit when fully ripened.

Kinds of THE GrnœCIUM.-The gynœcium is composed either of separate carpels, as in the Fukujusō (Adonis amurensis) and Kimpoge (Fig. 72), or of more or less united ones, as in the Oniyuri (Fig. 73) and Sumire (Fig. 74). In the former case it is said to be Apocarpous, and in the latter Syncarpous.

\section{KINDS OF TIEE GYNÆCIUM $\left\{\begin{array}{l}\text { Apocarpous Gynœcium. } \\ \text { Syncarpous Gynœcium. }\end{array}\right.$}

FIG. 72.

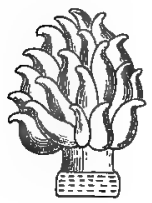

Fig. 72.-Multiple apocarpous gynoecium of the Kimpōge ( $R a$ nunculus acris).

'The apocarpous gynœcium may consist of either but one carpel, as in the Sakura (Fig. 55) and Yendū, or two or more, as in the Kimpōge (Fig. 72) and Fukujusō. In the former case it is said to be Simple, and in the latter Multiple.

In the multiple apocarpous gynœcium the ventral suture of each carpel is turned inwards.

\section{ApOCARPOUS GYNGCIUM $\left\{\begin{array}{l}\text { Simple Apocarpous Gynocium. } \\ \text { Multiple Apocarpous Gynoecium. }\end{array}\right.$}

The syncarpous gynœeium may be two- or more-celled being composed of two or more completely closed carpels, as in the Oniyuri (Fig. 73) and Nashi, or one-celled being composed of those more or less open carpels which are united together by their contiguous margins, as in the Keshi and Sumire (Fig. 74), or one-celled from the rupture of dissepiments, as in the Hakobe (Stellaria media) and Gampi.

The syncarpous gynœcium of the first kind is said to be Multilocular, and that of the second and the third Unilocular. 
FIG. 73.

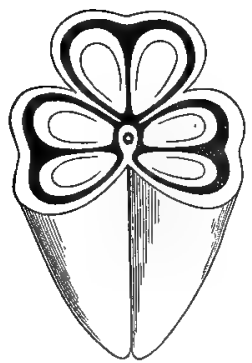

FIG. 73.-Cross section of the multilocular syncarpous gynoecium of the Oniyuri, showing axile placentation.
FIG. 74.

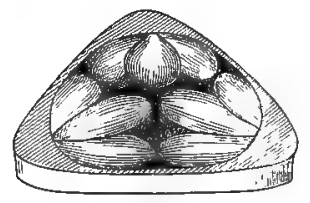

Fig. 74.-Cross section of the unilocular syncarpous gynocium of the Sumire, showing parietal placentation.

\section{SYNCARPOUS GXNGCIUM $\left\{\begin{array}{l}\text { Unilocular Syncarpous Gynœcium. } \\ \text { Multilocular Syncarpous Gynœcium. }\end{array}\right.$}

In the apocarpous gynoecium, as the placenta is always situated on the interior suriace of the ovary, the placentation (the manner in which the placentas are distributed) is said to be Parietal (Fig. 55). In the multilocular syncarpous gynceium, as the placentis are arranged in the centre, the placentation is said to be Axile (Fig. 73). In the unilocular syncarpous gynœcium composed of those open carpels which are united together by their contiguous margins, the placentation is mostly Parietal (Fig. 74). But, in the unilocular syncarpous gynoecium composed of those carpels which have Iost their dissepiments, as the placentas are situated in the centre of the cavity and perfectly unconnected with the wall, the placentation is said to be Free Central; and in the ordinary unilocular syncarpous one, the free central placentation is sometimes formed by the growth of a placental column from the base of the ovary-cavity. (See Fig. 78.)

All the kinds of gynocium are represented in the following table.

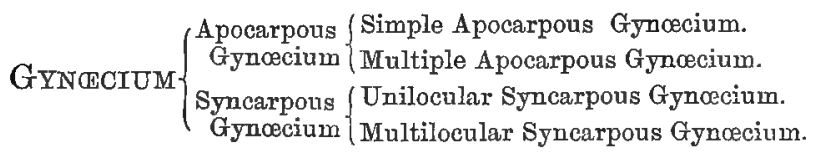




\section{THE FRUIT.}

The Fruit is the ripened gynocium, and it contains one or more seeds which are the ripened ovules.

Parts of the FrUIT.-The ordinary fruit consists of two parts : namely, of the fruit-coat called the Pericarp, which is either thin, as in the Kabura and Daidzu, or thick, as in the Mume and Momo (Fig. 84); and of one or more seeds. Although the pericarp consists normally of the mature ovary-coat or ovary-coats, as in the Mume and Kaki, sometimes the calyx and receptacle (page 75) also enter into its composition, as in the Nashi, (Fig. 86) and Ringo (Pyrus Malus, var. tomentosa).

When very thick, the pericarp is divisible into three layers, an external called the Exocarp; a middle, the Mesocarp; and an inner, the Endocarp. The exocarp is mostly tough and thin; the mesocarp often very thick and fleshy; and the endocarp is sometimes thick and very hard.

When thick and very hard the endocarp is termed the Stone or Putamen; such endocarp is seen in the fruits of the Mume and Momo (Fig. 84).

PARTS OF THE FRUIT $\left\{\begin{array}{l}\text { Pericarp }\left\{\begin{array}{l}\text { Exocarp. } \\ \text { Mesocarp. } \\ \text { Endocarp. }\end{array} \text { Seeds. }\right.\end{array}\right.$

DURATion of the FrUIT.-Some fruits fall off when fully ripe, as those of the Mume and Morno, but others remain permanently on the stem even after the plant dies, as those of the Daidzu and Togarashi (Capsicum longum). Those of the former kind are said to be Deciduous, and those of the latter Persistent.

DURATTON OF THE FRUIT $\left\{\begin{array}{l}\text { Deciduous. } \\ \text { Persistent. }\end{array}\right.$ 
KINDS of THE FRUIT.--Some fruits are formed from single flowers, as those of the Sakura (see Fig. 55) and Momo (Fig. 84), while others are formed by the combination of several flowers, as those of the Kuwa (Morus alba) (Fig. 88) and Ichijiku (Ficus carica). Those of the former kind are said to be Monothalamic, and those of the latter Polythalamic.

\section{KINDS OF THE FRUIT $\left\{\begin{array}{l}\text { Monothalamic Fruit. } \\ \text { Polythalamic Fruit. }\end{array}\right.$}

Monothalamic fruits may be composed either of one or more separate mature carpels, as in the Momo (Fig. 84) and Kimpūge (Fig. 72), or of more or less united mature carpels, as in the Kabura and Nashi (Fig. 86). In the former case, they are said to be Apocarpous, and in the latter Syncarpous.

$$
\text { MoNothaLAMIC FRUIT }\left\{\begin{array}{l}
\text { Apocarpous Fruit } \\
\text { Syncarpous Fruit. }
\end{array}\right.
$$

Apocarpous fruits may be also Simple or Multiple.

$$
\text { APOCARPOUS FRUIT }\left\{\begin{array}{l}
\text { Simple Apocarpous Fruit. } \\
\text { Mrultiple Apocarpous Fruit. }
\end{array}\right.
$$

Monothalamic fruits whether apocarpons or syncarpous are either dry, as in the Kimpoge and Kabura, or fleshy, as in the Momo (Fig. 84) and Nashi (Fig. 86).

$$
\text { Monothalamic FRUit }\left\{\begin{array}{l}
\text { Drg Monothalamic Fruit. } \\
\text { Fleshy Monothal.umic Fruit. }
\end{array}\right.
$$

Some of the dry monothalamic fruits burst open or separate into pieces when mature, as those of the Ingen (Phaseolus vulgaris) (Fig. 76) and Nagashirami (Osmorhiza japonica) (Fig. 79); while others remain closed, as those of the Kimpoge (Fig. 72) and Tögarashi (Fig. 81). Those of the former kind are said to be Dehiscent, and those of the latter Indehiscent.

Dry Monothalamic FRUIT $\left\{\begin{array}{l}\text { Dehiscent Dry Monotbalamic Fruit. } \\ \text { Indehiscent Dry Monothalamic Fruit. }\end{array}\right.$ 
Among dehiscent dry monothalamic fruits, some are apocarpous and each one opens by one suture only, as in the Yamaodamaki (Aquilegia Buergeriana) (Fig. 75) and Torikabuto; some are also apocarpous and each one opens by two sutures, as in the Daidzu and Ingen (Fig. 76); some

FIG. 75.

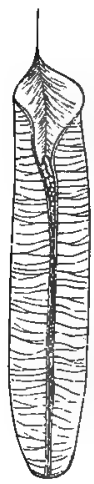

Fig. 75.-Follicle of the Yamaodamaki (Aquilegia Buergeriana).

Fig. 77.

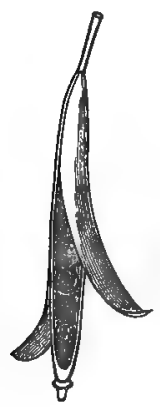

Fig. 77.-Capsule of Cardamine.
FIG. 76.

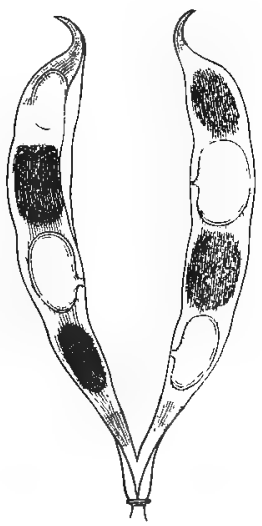

Fig. 76.-Legume of the Ingen

(Phaseolus vulgaris).

FIG. 78.

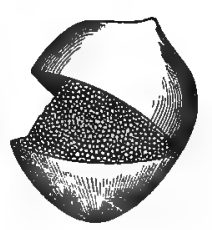

Fra. 78.-Capsule of the Matsubabotan (Portulaca grandiflora). 
Frg. 79.

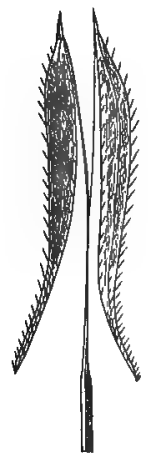

FIG. 79.-Schizocarp of the Nagashirami

are syncarpous and burst open, as in the Kabura (see Fig. 77), Matsubabotan (Portulaca grandiflora) (Fig. 78), and Tsubaki; and others are also syncarpous and separate into their constituent carpels without opening, as in the Ninjin and Nagashirami (Fig. 79). In the first case the fruit is called the Follicle; in the second, the Legume; in the third, the Capsule; and in the last, the Schizocarp.

(Osmorhiza japonica).

$$
\text { DEHISCENT DRY MONOTHALAMIO FRUIT }\left\{\begin{array}{l}
\text { Follicle. } \\
\text { Legume. } \\
\text { Capsule. } \\
\text { Schizocarp. }
\end{array}\right.
$$

Among indehiscent dry monothalamic fruits, some have hard pericarps and are usually one-seeded, as in the ShiraFre. 80. Fir. 81.

FIG. 82.

FIG. 83.
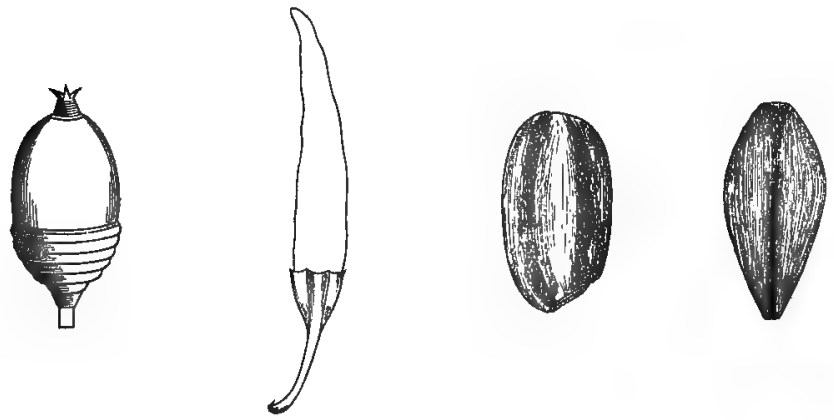

Fig. 80,-Nut of the Shirakashi (Quercus glauca).
Fia. 81.-Indehiscent capsule of the Tōgarashi (Capsicum longum).
FIG. 82-Grain Fra. 83.-Grain of the Ine. of the Omugi (Hordeum vulgare). 
kashi (Quercus glauca) (Fig. 80) and Kuri (Castanea vulgaris, var. japonica); some have not hard pericarps and are usually many-seeded, as in the Daikon and Togarashi (Fig. 81); some are small and somewhat seed-like, each fruit being provided with a pericarp separable from the seed or seeds, as in the Kimpōge (Fig. 72) and Fukujusō; and others are also small, each one being provided with such a pericarp as is inseparably united with the seed, as in the Ine (Fig. 82) and Ōmugi (Hordeum vulgare) (Fig. 83). In the first case the fruit is called the $N u t$; in the second, the Indehiscent Capsule; in the third, the Achene; and in the last, the Grain or Caryopsis.

INDEHISCENT DRY MONOTHALAMTC FRUIT $\left\{\begin{array}{l}\text { Nut. } \\ \text { Indehiscent Capsule. } \\ \text { Achene. } \\ \text { Grain. }\end{array}\right.$

FIG. 84.

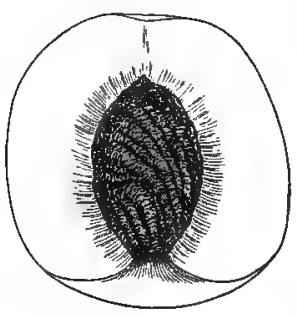

Fia. 84.-Drupe of the Momo (Prunus persica).

In some of the fleshy monothalamic fruits, as those of the Mume and Momo (Fig. 84), the endocarp is very hard and called the stone; while in others as those of the Budo (Fig. 15) and Kaki, the endocarp is not so hard. Those fruits, in which the endocarp is very hard, are called Drupes.

FLESHY MONOTH. FR. $\left\{\begin{array}{l}\text { Fleshy Monoth. Fr. with a stone-Drupe. } \\ \text { Fleshy Monoth. Fr. without a stone. }\end{array}\right.$

In some of the fleshy monothalamic fruits in which the endocarp is not so hard, the pericarp is soft throughout, as in the Kaki and Budo (Fig. 15); in some, the pericarp is soft internally and hard externally, as in the Tounasu 
(Cucurbita Pepo) and Hyōtan (Lagenaria vulgaris) (Fig. 85 ) ; and in others, the endocarp is papery, cartilaginous, or bony, and surrounded by a thick flesh which belongs chiefly to the adnate calyx, as in the Nashi (Fig. 86) and Ringo.

FIG. 85.

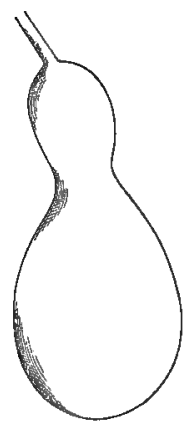

FIG. 85.-Pepo of the Hyōtan (Lagenavia vulgaris).
FIG. 86.

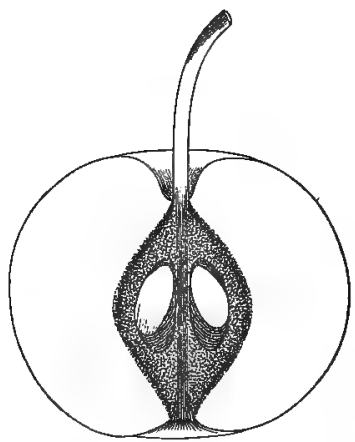

FIa. 86.-Pome of the Nashi (Pyrus sinensis).

In the first case the fruit is called the Berry; in the second, the Pepo; and in the last, the Pome.

Fleshy monoth. FR. Without a stone $\left\{\begin{array}{l}\text { Berry. } \\ \text { Pepo. } \\ \text { Pome. }\end{array}\right.$

FIG. 87.

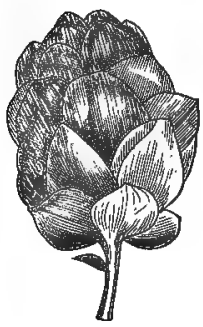

FIg. 87.-Dry polythalamic fruit of the Karahanaso (Humulus Latpulus).
Fig. 88.

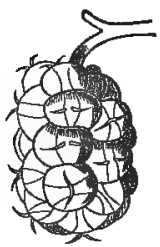

FIG. 88.-Fleshy polythalamic iruit of Morus. 
Among polythalamic fruits also, some are dry as in the Akamatsu and Karahanaso (Humulus Lupulus, var. cordifolius) (Hig. 87), while others are fleshy as in the Kuwa (Fig. 88) and Ichijiku.

\section{Polythalamic FRdit $\left\{\begin{array}{l}\text { Dry Polythalamic Fruit. } \\ \text { Fleshy Polythalamic Fruit. }\end{array}\right.$}

All the kinds of fruits are represented in the following table.

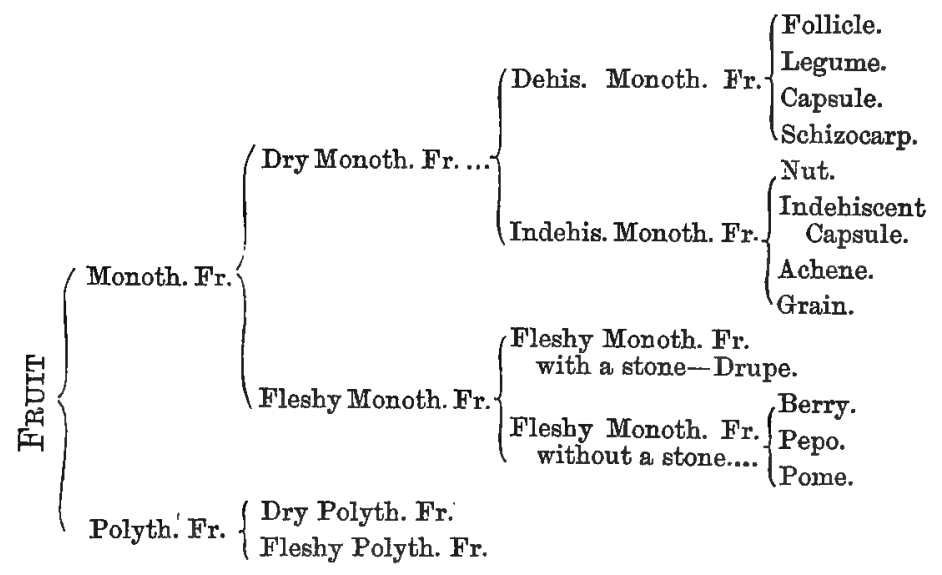

THE SEED.

The Seed is the ripened ovule and it always contains a rudimentary plant called the Embryo.

PaRTs of THE SEED.-The seed consists of the inner substance called the Kernel and its integuments termed the Seed-coats.

The kernel consists of the embryo alone as in the seeds of the Daidzu and Kabura, or of the embryo and its nutritive matter called the Albumen as in those of the Asagao and Ine. 
The embryo being the rudimentary plant consists of an axis and one or more leaves. The apex of the axis is called the Plumule, its lower end the Radicle, its portion between the plumule and the radicle the Caulicle, and the leaves bear the name of Cotyledons.

The seed-coats usually consist of two layers ; namely, of the exterior integument called the Testa which is thick and often very hard, and of the interior one called the Tegmen which is commonly thin and delicate.

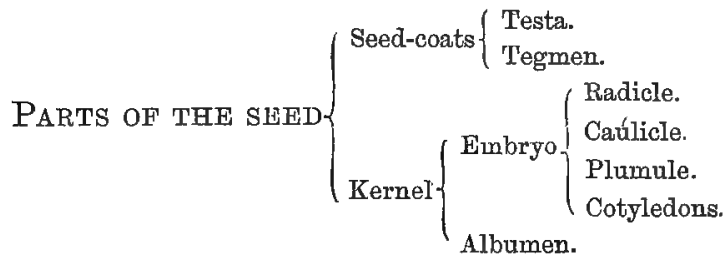

Kinds of THE SEED.-In some seeds, as those of the Ayame and Ōmugi (Fig. 89), the embryo has only one cotyledon; in some, as those of the Asagas (Fig. 90) and

Fig. 89.

FIG. 90.

FIG. 91.

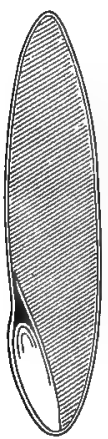

Frg. 89.-Monocotyledonous seed of the Omugi.

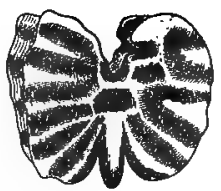

FIG. 90.-Dicotyledonous seed of. the Asagao.

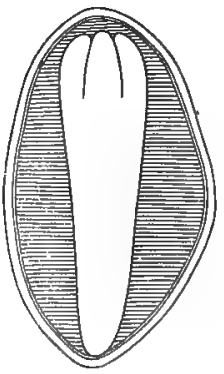

Fia. 91.-Polycotyledonous seed of the Alsamatsu. 
Daidzu, it has two cotyledons; and in others, as those of the species of Pinus (Fig. 91), it has three or more cotyledons.

In the first case the seed is said to be Monocotyledonous; in the second, Dicotyledonous; and in the last, Polycotyledonous.

$$
\text { KINDS OF THE SEED }\left\{\begin{array}{l}
\text { Monocotyledonous Seed. } \\
\text { Dicotyledonous Seed. } \\
\text { Polycotyledonous Seed. }
\end{array}\right.
$$

KINDS OF THE FLOWER.

Flowers vary according to either their floral envelopes, or their essential organs, so that they may be classified in two ways.

\section{IINDS OF FLOWERS ACCORDING TO THETR FLORAL ENVELOPES.}

In some plants as the Mume and Sakura (Fig. 55) the flower possesses the corolla, while in others as the Jinchöge (Daphne odora) and Nawashirogumi (Elaagnus pungens) (Fig. 94) it does not possess the corolla. In the former case the flower is said to be Petalous or Dichlamydeous, and in the latter Apetalous.

$$
\text { FLOWER }\left\{\begin{array}{l}
\text { Petalous Flower. } \\
\text { Apetalons F'lower. }
\end{array}\right.
$$

In some of the petalous flowers, the corolla is dialypetalous as in the Kabura (Fig. 54) and Sakura (Fig 55); while in others it is Gamopetalous as in the Asagao (Fig. 9) and Odorikoso (Fig. 59). In the former case the flower is said to be Dialypetalous, and in the latter Gamopetalous.

$$
\text { Petalods FLOWER }\left\{\begin{array}{l}
\text { Dialypetalous Flower. } \\
\text { Gamopetalous Flower. }
\end{array}\right.
$$

In some of the dialypetalous flowers, the corolla is quite separated from the calyx, as in the Kabura (Fig. 54) and 
Kimpoge ; while in others, the corolla arises from the calyx, as in the Mume and Sakura (Fig. 55). The flowers of the former kind are said to be Free Dialypetalous, and those of the latter Adherent Dialypetalous.

\section{DiALIPE'TALOUS FLOWER $\left\{\begin{array}{l}\text { Free Dialypetalous Flower. } \\ \text { Adherent Dialypetalous Flower. }\end{array}\right.$}

Free dialypetalous flowers may be either Regular as in the Kabura (Fig. 54) and Kimpoge, or Irregular as in the Sumire (Fig 56) and Murasakikeman (Corydalis incisa).

$$
\text { FreE DIALYPETALOUS FLOWER }\left\{\begin{array}{l}
\text { Regular Free Dialypetalous } \\
\text { Flower. } \\
\text { Irregular Free Dialypetalous } \\
\text { Flower. }
\end{array}\right.
$$

Adherent dialypetalous flowers also may be sometimes Regular as in the Mume and Sakura (Fig. 55) or at other times Irregular as in the Fuji (Fig. 57) and Ingen.

$$
\text { ADHERENT DIAL YPETALOUS FLOWER }\left\{\begin{array}{c}
\text { Regular Adherent Dialy- } \\
\text { petalous Flower. } \\
\text { Irregular Adherent Dialy- } \\
\text { petalous Flower. }
\end{array}\right.
$$

In some of the irregular adherent dialypetalous flowers, the androeium is united with the style, and such flowers are said to be Orchidaceous; and in some again, the corolla consists of five petals, of which the outermost one is usually the largest, the innermost two are often coherent in front inclosing the essential organs, and the lateral two are somewhat wing-like, and such flowers are said to be Papilionaceous (Fig. 57).

In some gamopetalous flowers, the ovary or ovaries are united with the calyx tube, as in the Tampopo (Fig. 58) and Hakone-utsugi (Diervilla grandiflora) (Fig. 92); while in others, the ovary or ovaries are quite separated from the calyx, as in the Tsutsuji and Sagigoke (Fig. 93). In the former case, the flower is said to be Epigynous, and in the latter Hypogynous. 
FIG: 92.

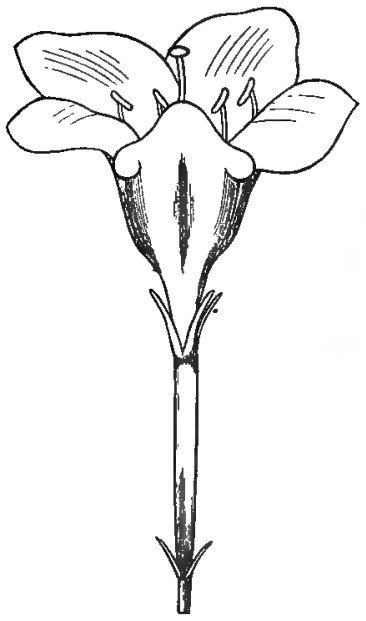

FIs. 92.-Flower of the Hakone-utsugi (Dievvilla grandiflora).
FIG. 93.

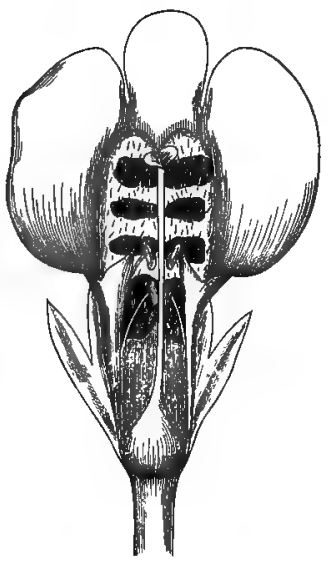

Fra. 93.- Flower of the

Sagigoke (Mazus r'ugosus) cut open.

GaMOPETALOUS FLOWER $\left\{\begin{array}{l}\text { Epigynous Gamopetalous Flower. } \\ \text { Hypogynous Gamopetalous Flower. }\end{array}\right.$

Epigynous gamopetalous flowers may be either Regular as in the Hakone-utsugi (Fig. 92) and Kikyō (Platycodon grandiflorum), or Irregular as in the Tampopo (Fig. 58) and Nindō (Lonicera japonica).

Eligynous gamopetalous flower $\left\{\begin{array}{l}\text { Regular Epig. Gamop. FI. } \\ \text { Irregular Epig. Gamop. Fl. }\end{array}\right.$

Hypogynous gamopetalous flowers also may be either Regular as in the Asagao (Fig. 9) and Salzuraso (Primula cortusoides), or Irregular as in the Kiri and Sagigoke (Fig. 93).

Hipogynods gamopetalods FLower Reg. Hypog. Gamop. Fl. Irreg. Hypog. Gamop. Fl. 
In some of the irregular hypogynous gamopetalous flowers, the corolla is five-lobed and the limb is divided into two portions, which are placed superiorly and inferiorly, somewhat resembling the lips and open mouth of an animal, and such fiowers are said to be Labiate (F'ig. 59); and in others, petals are united on one side to form a flattened strap, and such flowers are said to be Ligulate (Fig. 58).

FIG. 94.

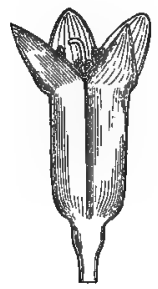

Frg. 94.-Flower of the Nawashirogumi (Elaagnus pungens).
FIG. 95.

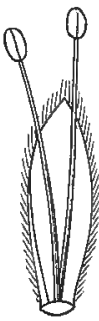

FIg. 95.-Male flower of the Shidareyanagi.
Frg. 96.

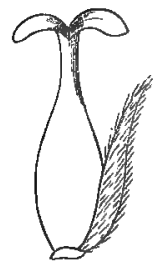

FIg. 96.-Female flower of the Shidareyanagi.

In some of the apetalous flowers, the calyx is present as in the Jinchōge and Nawashirogumi (Fig. 94); while in others, it is absent as in the Akamatsu and Shidareyanagi (Fig. 95 and 96). In the former case, the flower is said to be Monochlamydeous, and in the latter Achlamydeous.

APETALOUS FLOWER $\left\{\begin{array}{l}\text { Monochlamydeous Flower. } \\ \text { Achlamydeous Flower. }\end{array}\right.$

2. KINDS OF FLOWERS ACCORDING TO THEIR ESSENTLAL ORGANS.

In some cases, the androecium and the gynoecium may be both present, as in the Mume and Sakura (Fig. 55); in some cases, either the androcium or the gynœcium may be absent, that is, only one of the essential organs may be present, as in the Shidareyanagi (Fig. 95 and 96) and Akamatsu; and in other cases, the essential organs may be altogether 
wanting, as the outermost flowers of the Yagurumagiku FIg. 97. (Centaurea Cyanus) and Ajisai (Hy-

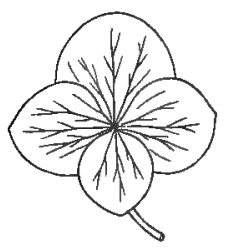

FIG. 97.-Neutral flower of the Ajisai (Hydrangea hortensis, var. Azisai). drangea hortensis, var. Azisai) (Fig. 97). Those flowers which possess both essential organs are said to be Bisexual or Hermaphrodite; those in which only one is present are Unisexual or Diclinous; and those which possess neither androcium nor gynocium are Neutral.

KINDS OF FLOWERS ACCORDING TO THEIR
ESSENTIAL ORGANS $\left\{\begin{array}{l}\text { Bisexual Flower. } \\ \text { Unisexual Flower. } \\ \text { Neutral Flower. }\end{array}\right.$

When a flower consists of four parts; namely, calyz, corolla, androcium, and gynœcium, as in the Kabura and Sakura, it is said to be Complete.

When a flower wants one or more parts, as in the Jinchoge and Shidareyanagi, it is said to be Incomplete.

When each part of a flower consists of an equal number of constituents. or the constituents of one part are multiples of those of another, as in the Ama (Linum usitatissimum) and Kirinsō (Sedum kamtschaticum), the flower is said to be Symmetrical.

When each part of a flower consists of an unequal number of constituents or the constituents of one part are not multiples of those of another, as in the Keshi and Mume, the flower is said to be Unsymmetrical.

\section{HYPSOPHYLLARY LEAVES OR BRACTS.}

The Hypsophyllary Leaves or Bracts are modified leaves situated below the flower or flowers. They are developed either singly as in the Tennanshō (Fig. 53) and Ayame, or in whorls as in the Ichirinsō (Anemone nikoensis) (Fig. 98) and Riunōgiku (Chrysanthemum sinense, var. japonicum) (Fig. 99). In the former case, they are said to be Scattered, and in the latter, Verticillate. 
F1G. 98.

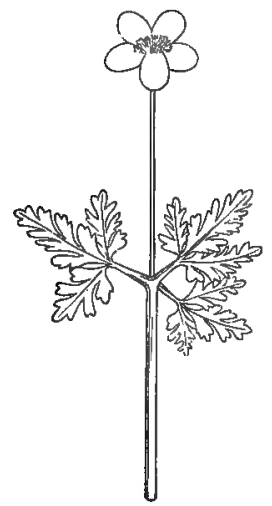

FIG. 98.-Ichirinsō

(Anemone nikoensis).
FIG. 99.

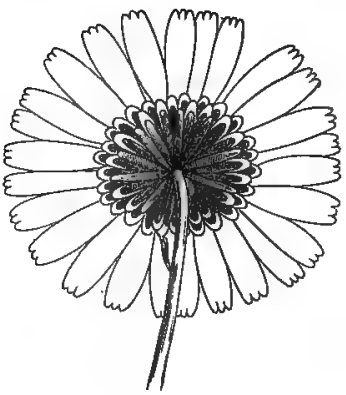

F'IG. 99.-Flower-clusters of the Riunögiku (Chrysanthemum sinense, var. japonicum).

\section{BRACTS $\left\{\begin{array}{l}\text { Scattered. } \\ \text { Verticillate. }\end{array}\right.$}

\section{THE INFLORESCENCE.}

The arrangement of the flowers on the axis is termed the Inflorescence.

Parts of the Inflorescence.-In a well developed inflorescence, there is a common axis, branched or not branched, on which stalked or sessile flowers and usually bracts are developed. The axis is called the Peduncle; the stalk of the flower, the Pedicel; and the apex of the pedicel or peduncle, upon which the parts of a flower are arranged, the Receptacle. Sometimes the peduncle is more or less dilated and bears numerous flowers; it is then called the Common Receptacle. (See Fig. 17.)

PARTs of THE INFLORESCENCE $\left\{\begin{array}{l}\text { Peduncle. } \\ \text { Flowers with or without Pedicels. } \\ \text { Bracts. }\end{array}\right.$ 
Kinds of THE InfLORESCENCE.-In some plants, the main axis or common peduncle of the inflorescence is not terminated by a flower, as in the Kabura and Fuji (see Fig. 100); while in others, the common peduncle is terminated by a flower, as in the Nadeshiko and Kinshibai (see Fig. 104). The former kind is called the Indefinite, and the latter the Definite Inflorescence. In the indefinite inflorescence with an elongated common peduncle, as the flowers open in succession from below upwards, it is also called the Ascending (Fig 100 and 101). When the common peduncle is shortened, the flowers open from the circumference towards the centre, as in the Shion and Tampopo, and the inflorescence is again termed the Centripetal (Fig. 103). In the definite inflorescence with an elongated common peduncle, the flowers open in succession from above downwards; hence it is also called the Descending (Fig. 104). When the common peduncle of this inflorescence is shortened, the flowers open from the centre towards the circumference, as in the Yamabōshi (Cornus kousa) and Gozentachibana (C. canadensis), and the inflorescence is likewise termed the Centrifugal.

KINDS OF THE INFLORESCENCE $\left\{\begin{array}{l}\text { Indefinite Inflorescence. } \\ \text { Definite Inflorescence. }\end{array}\right.$

Among ascending inflorescences, some bear pedicellate flowers, as in the Kabura and Fuji; while others bear sessile or very short pedicellate flowers, as in the Ōbako and Shidareyanagi. The former kind is called the Raceme (Fig. 100) and the latter the Spike (Fig. 101).

AsCENDING INFLORESCEnCE $\left\{\begin{array}{l}\text { Raceme. } \\ \text { Spike. }\end{array}\right.$ 
Fig. 100.

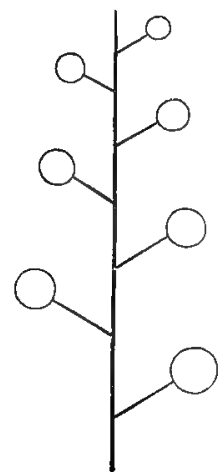

FIG. 100.-Raceme.

F'IG. 102.

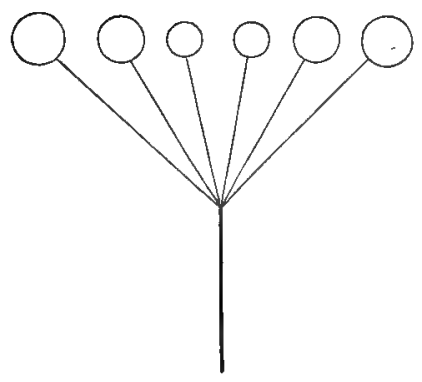

FIG. 102.-Umbel.
FIG. 101.

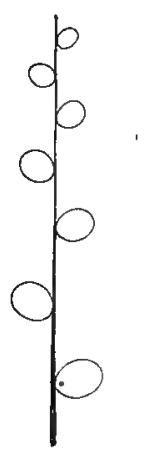

FIG. 101.-Spike.

FIG. 103.

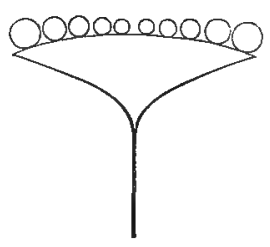

Among centripetal inflorescences, some bear pedicellate flowers, as in the Ninjin and Nodake; while others bear sessile flowers, as in the Shion and Tampopo. The former kind is called the Umbel (Fig. 102), and the latter the Capitulum (Fig. 103).

Centripetal INFLORESCENCE $\left\{\begin{array}{l}\text { Umbel. } \\ \text { Capitulum. }\end{array}\right.$

Among definite inflorescences, some bear only one flower, as in the Fukujusō and Ichirinsō (see Fig. 98); some bear 
FIG. 104.

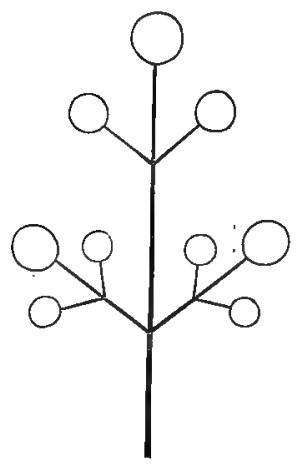

Fra. 104.-Pleiochasial cyme.

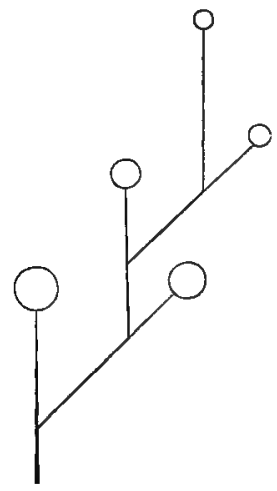

numerous flowers the terminal one of which is situated in the centre, as in the Nadeshiko and Kinshibai; and some bear numerous flowers the terminal one of which is situated lowermost, as in the Mōsengoke and Tabirako. The first kind is called the Simple inflorescence; the second kind, the Pleiochasial Cyme (Fig. 104); and the last, the False Raceme or Sympodial Cyme (Fig. 105).

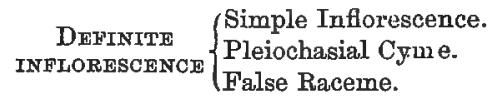

FIa. 105.

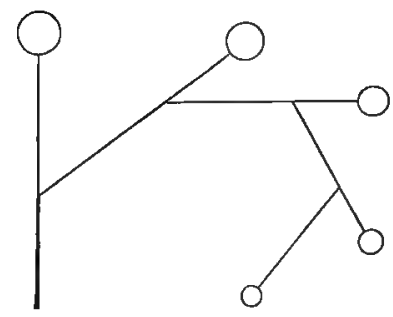

FIg. 105.-False raceme.

All the kinds of inflorescence are represented in the following table.

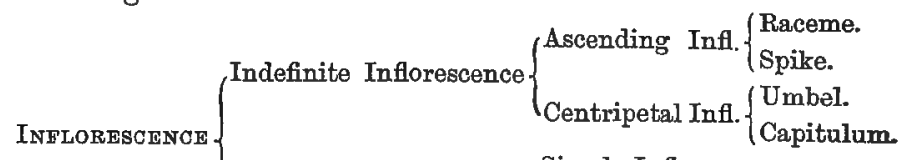
Definite Inflorescence $\left\{\begin{array}{l}\text { Simple Inflorescence. } \\ \text { Pleiochasial Cyme. } \\ \text { False Raceme. }\end{array}\right.$ 
SPORE-BEARING LEAVES. FIG. $106^{\circ}$

The Spore-bearing Leaves are those, which bear minute bodies called the spores that answer to seeds. (See Fig. 51.)

KINDS OF SPORE-BEARING LEAVES.-Soma sporebearing leaves may perform only the reproductive function, as those of the Zemmai (Osmunda regalis) and Shishigashira (Lomxria Spicant) (Fig. 106); while others may perform the nutritive function at the same time, as those of the Nokishinobu (Fig. 51) and Warabi.

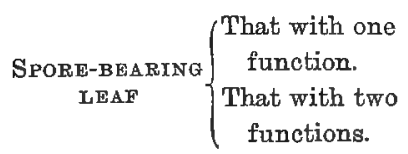

FIG. 106.-Shishigashira (Lomaria Spicant), showing foliage leares and a spore-bearing one.

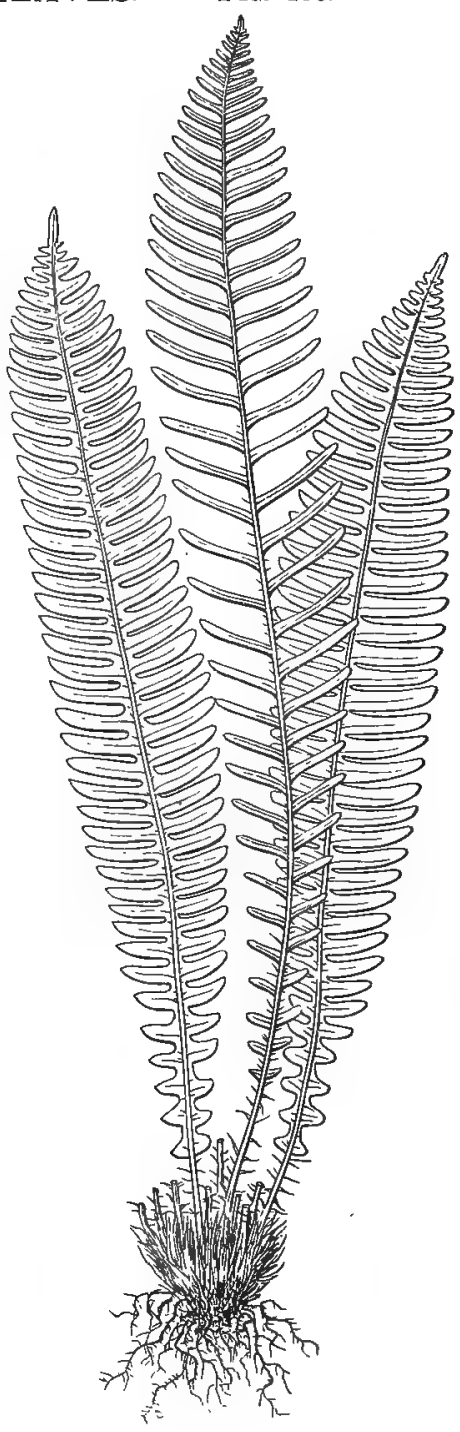




\section{SUMMARY.}

The leaf is that part of a plant, which is always developed laterally on the stem and is usually of a flattened nature.

The base of the leaf is its organically lower end.

The apex of the leaf is its organically upper end.

The body of the leaf is the portion lying between the base and the apex.

The leaf is said to be coriaceous when its texture is tough and leathery.

The leaf is said to be herbaceous when its texture is weak and soft.

The leaf is said to be suceulent when its texture is thick and juicy.

The leaf is said to be membranous when its texture is thin and flexible.

The leaf is said to be annual when it dies the same year in which it is developed.

The leaf is said to be biennial when it dies the second year.

The leaf is said to be perennial when it lives for many years.

The aerial leaf is one which exists exposed to the air.

The aquatic leaf is one which exists submersed in water.

The subterranean leaf is one which exists buried in the soil.

'The foliage leaf is one which is always green, mostly flattened, and does not produce reproductive organs.

The modified leaf is one which differs from the foliage leaf.

The lamina is that part of a foliage leaf, which is usually expanded and situated above other portions.

The petiole is that portion of a foliage leaf, which stands between the lamina and the leaf-sheath and is usually semicylindrical.

The leaf-sheath is that portion of a foliage leaf, which stands below the petiole and embraces the stem more or less assuming a tubular or sheathlike form.

Stipules are small leafy appendages situated one on each side of the leaf sheath.

Veins are the woody thread-like structures in the lamina.

The venation is the mode of veining.

Ribs are large veins proceeding from the base to the apex of a lamina.

The midrib is the most prominent central rib.

When veins are distributed to form a kind of network, the venation is said to be netted-veined.

When veins are distributed paralled to one another, the venation is said to be parallel-veined.

When the netted-reined lamina has but one central rib, the venation is said to be pinnately veined. 
When the netted-veined lamina has two or more ribs, the venation is said to be palnately veined.

When the palmately.veined lamina has diverging ribs, the venation is said to be divergipalmately veined.

When the palmately veined lamina has converging ribs, the venation is said to be convergipalmately veined.

When the parallel-veined lamina has but one rib, the venation is said to be costal-nerved.

When the parallel-veined lamina has several ribs, the venation is said to be basal-nerved.

When the basal-nerved lamina has diverging ribs, the venation is said to be flabellinerved.

When the basal-nerved lamina has converging ribs, the venation is said to be longitudinal-nerved.

When the lamina can be divided longitudinally into two similar haltes, it is said to be symmetrical.

When the lamina can not be divided longitudinally into two similar halves, it is said to be unsymmetrical.

When the symmetrical lamina can be divided again by a lateral plane into two similar halves up and down, it is said to be disymmetrical.

When the symmetrical lamina can not be divided again by a lateral plane into two similar halves up and down, it is said to be monosymmetrical.

When its margins are without notches of any kind, the lamina is said to be entive.

When its margins present notches of some kind, the lamina is said to be uneven.

When its margins are cut into small indentations, the lamina is said to be dentate.

When its margins are cut into divisions extending not more than half way down, the lamina is said to be lobed.

When its margins are cut into divisions extending more than half way down, the lamina is said to be parted.

When its margins are cut into divisions reaching to the midrib or the base, the lamina is said to be divided.

When the apex of the lamina is sharp, it is said to be acute.

When the apex of the lamina is rounded, it is said to be obtuse.

When the apex of the lamina is abruptly pointed, it is said to be mucronate.

When the apex of the lamina is straight as if cut across, it is said to be trincate. 
When the apex of the lamina is more or less notched, it is said to be emarginate.

When the lamina arises immediately from the stem, its insertion is said to be direet.

When the lamina is attached to the stem by means of the petiole or the leaf-sheath, its insertion is said to be indirect.

When the lamina whose insertion is direct has its margins not at all united except at the point where it is attached to the stem, its insertion is again said to be free.

When the lamina whose insertion is direct has its prolonged basilar lobes more or less united with the stem, its insertion is again said to be adnate.

When the lamina whose insertion is indirect is attached to the petiole or the leaf-sheath by its base, its insertion is again said to be basal.

When the lamina, whose insertion is indirect is attached to the petiole by a point more or less within its margins, its insertion is again said to be intramarginal.

When leaves are produced singly at each node, they are said to be scattered.

When two or more leaves are produced at the same node, they are said to be polymerous.

When scattered leaves are produced on a stem with elongated internodes, they are said to be alternate.

When scattered leaves are produced on a branch of which the internodes do not elongate, they are said to be fascicled.

When two leaves are produced at node on opposite sides of the stem, they are said to be opposite.

When three or more leaves are so produced at a node that the distance between any two adjacent lenves is equal, they are said to be verticillate.

The angular divergence is the lateral distance between the bases of any two adjacent leaves.

Simple leaves are those which have only one lamina and never more than one articulation at the base.

Compound leaves are those which have two or more laminae or one lamina and two articulations.

Compound leaves with one lamina are said to be unifoliolate.

Compound leaves with two or more laminae are said to be multifoliolate.

The laminae of compound leaves are termed leaflets.

The stalks of leaflets are termed petiolules.

The stipules of leaflets are termed stipels.

Pinnately compound leaves are those which have their leaflets arranged. laterally on a common petiole. 
Palmately compound leaves ar 3 those which have their leaflets arranged on the top of a common petiole.

Nutritive modified leaves are those which are related either directly. or indirectly to the nutrition of the plant to which they belong.

Reproductive modified leaves are those which are related either directly or indirectly to reproduction.

Spines are those nutritive modified leaves or branches which are hard and needle-shaped.

Tendrils are those nutritive modified leaves or branches which are threadlike and capable of coiling spirally.

Cataphyllary leaves are those nutritive modified ones which are small and scaly.

Insectivorous leaves are those nutritive modified ones which are capable of catching insects.

The flower is an assamblage of numerous reproductive modified leaves.

Floral leaves are those ruproductive modified ones which constitute the flower.

Hypsophyllary leaves are those reproductive modified ones which are situated below a flower or flowers.

Spore-bearing leaves are those reproductive modified ones which bear minute fructifications.

Protective organs of a flower are the floral envelopes consisting of the calyx and the corolla.

Essential organs of a flower are the androcium and gynocium.

The caly $x$ is the outermost envelope of the flower and it is composed of flattened usually green organs.

Sepals are those floral leaves which constitute the calyx.

The calyz is said to be caducous, when it falls off as the flower expands.

The calyz is said to be deciduous, when it falls off with or after the corolla.

The calyx is said to be persistent, when it remains after the flowering is over.

The dialysepalous caly $x$ is one which consists of distinct sepals.

The gamosepalous calyx is one which consists of wore or less united sepals.

The regular dialysepalous calyx is one which consists of distinet sepals of equal size and like form.

The irregular dialysepalous calyx is one which consists of distinct sepals of unequal size and unlike form.

The regular gamosepalous calyx is one which consists of more or less united sepals of equal size and like form. 
The irregular gamosepalous calyx is one which consists of more or less united sepals of unequal size and unlike form.

The tube of the gamosepalous calyx is that part where the sepals are united.

The limb of the gamosepalous calyz is its free border.

The throat of the gamosepalous calyx is the orifice of its tube.

The corolla is the inner floral envolope situated within the calyx and it is composed of flattened usually colored organs.

Petals are those floral leaves which constitute the corolla.

The corolla is said to be caducous, when it falls off as the flower expands.

The corolla is said to be deciduous, when it falls off with or after the calyx.

The corolla is said to be persistent, when it remains after the flowering is over.

The dialypetalous corolla is one which consists of separate petals.

The gamopetalous corolla is one which consists of more or less united petals.

The regular dialypetalous corolla is one which consists of separate petals of equal size and like form.

The irregular dialypetalous corolla is one which consists of separate petals of unequal size and unlike form.

The regular gamopetalous corolla is one which consists of more or less united petals of equal size and like form.

The invegular gamopetalous corolla is one which consists of more or less united petals of unequal size and unlike form.

The limb of the petal is its expanded portion.

The claw of the petal is its stalls-like portion.

The tube of the gamopetalous corolla is that part where the petals are united.

The limb of the gamopetalous corolla is its free border.

The throat of the gamopetalous corolla is the orifice of its tube.

The andracium is the outer series of the essential organs situated within the corolla, and it is composed of one or more thread-like organs.

Stamens are those floral leaves which constitute the andrcecium.

The anther of the stamen is its bag-like portion.

The filament of the stamen is its stalk.

The anther-lobe is the longitudinal half of an anther.

The connective is that portion of ustamen which connects the two anther-lobes.

The anther-cell is the cavity of an anther-lobe. 
The pollen is a term used to denote the minute grains contained in the anther-cell.

The androecium is said to be deciduous, when it falls off after discharging the pollen.

The andrøcium is said to be persistent, when it remains after the flowering is over.

'The apostemonous androcium is one which consists of separate stamens.

The synstemonous androcium is one which consists of more or less united stamens.

The simple apostemonous androcium is one which consists of but one fertile stamen.

The multiple apostemonous andrcecium is one which consists of two or more separate stamens.

The multiple apostemonous androcium is said to be regular, when it consists of those stamens which are all of the same length and like form.

The multiple apostemonous androcium is said to be irregular, when it consists of those stamens which are of different length or unlike form.

The synstemonous andrœcium is said to be complete, when its stamens are united into one body.

The synstemonous androcium is said to be incomplete, when its stamens. are united into two or more bodis's.

The attachment of the anther is said to be adnate, when it is attached on its back throughout its whole length to the filament.

The attachment of the anther is said to be innate, when it is attached to the filament by its base.

The attachment of the anther is said to be versatile, when it is attached by a point near its centre to the tip of the filament.

When turned inwards, the anther is said to be introrse.

When turned outwards, the anther is said to be extrorse.

The act of discharging its contained pollen is called the dehiscence of the anther.

When the anther splits open longitudinally, its dehiscence is said to be longitudinal.

When the anther splits open transversely, its dehiscence is said to be transverse.

When the anther opens by holes, its dehiscence is said to be porous.

When the anther opens by uplifted valves, its dehiscence is said to be valvular.

The gynocium is the inner series of the essential organs occupying the centre of the flower, and it is composed of one or more usually sac-like organs. 
Carpels are those floral leaves which constitute the gynceium.

Gymnospermous carpels are those which are open and scale-like.

The ovary is that part of a carpel which is sac-like and contains one or more ovules.

The ovule is a small body borne by the placenta and it becomes the seed when the flowering is over.

The placenta is that portion of a carpel where the ovules are produced.

The style is that portion of a carpel which is situated between the ovary and the stigma.

The stigma is the usually dilated rough apex of a carpel.

The cavity of the ovary is termed its cell.

The inner suture is the line formed by the union of the leaf-margins of a carpel.

The outer' suture is the line on a carpel corresponding to the midrib.

The apocarpous gynocium is one that consists of one or more separate carpels.

The syncarpous gynocium is one that consists of more or less united carpels.

The simple apocarpous gynceium is one that consists of but one carpel.

The multiple apocarpous gynocium is one that consists of two or more separate carpels.

The unilocular syncarpous gynocium is one that is one-celled.

The multilocular syncarpous gynceizm is one that is two or more-celled. The fruit is the ripened gynocium, and it contains one or more seeds.

The pericarp is the fruit-coat.

The endocarp is the inner layer of the pericarp.

When thick and very hard the endocarp is termed the stone.

The mesocarp is the middle layer of the pericarp.

The exocarp is the external layer of the pericarp.

Fruits are said to be deciduous when they fall off from the stem.

Fruits are said to be persistent when they remain permanently on the stem.

Monothalamic fruits are those which are formed from single flowers.

Polythalamic fruits are those which are formed by the combination of several Howers.

Apocarpous fruits are those which consist of one or more separate mature carpels.

Syncarpous fruits are those which consist of more or less united mature carpels.

Simple apocarpous fruits are those which cosist of but one mature carpel. 
Multiple apocarpous fruits are those ?which consist of two or more separate mature carpels.

Dry nonothalamic fruits are those which become sap-less when fully ripe.

Fleshy monothalamic fruits are those which are pulpy.

Dry monothalamic fruits are said to be dehiscent when they burst open or separate into pieces.

Dry monothalamic fruits are said to be indehiscent when they remain closed.

The follicle is one of dry apocarpous fruits dehiscing by one suture alone.

The legume is one of dry apocarpous fruits dehiscing by both sutures.

The capsule is a dry syncarpous fruit which bursts open when fully matures.

The schizocarp is a dry syncarpous fruit which separates into its constituent carpels.

The nut is an indehiscent dry monothalamic fruit which has w hard pericarp and is usually one-seeded.

The indehiscent capsule is an indehiscent dry monothalamic fruit which has not a very hard pericarp and is usually many-seeded.

The achene is one of indehiscent dry apocarpous fruits, which is swall, seed-like, and is provided with a pericarp separable from the seed or seeds.

The grain is one of inclehiscent dry apocarpous fruits, which is small, seed-like, and has a thin pericarp consolidated with the seed.

The drupe is a fleshy monothalamic fruit which has a very hard endocarp.

The berry is a fleshy monothalamic fruit whose pericarp is soft throughout.

The pepo is a fleshy monothalamic fruit whose pericarp is soft internally and hard externally.

The pome is a fleshy monothalamic fruit whose eadocarp is papery, cartilaginous, or bony, and is surrounded by a thick flesh which belongs chiefly to the adnate calyx.

Polythalamic fruits are said to be dry when they become sap-less.

Polythalamic fruits are said to be fleshy when they are pulpy.

The seed is the ripened ovule.

The testa is the outer coat of a seed.

The tegmen is the inner coat of a seed.

The kernel is the body of a seed.

The embryo is the rudimentary plantlet formed in a seed.

The caulicle is the stem of an embryo. 
The radicle is the lower end of the caulicle.

The cotyledon is the leaf of an embryo.

The plumule is the upper end of the caulicle.

The albumen is any nutritive substance in the kernel of a seed.

The monocotyledonous seed is one whose embryo has but one cotyledon.

The dicotyledonous seed is one whose embryo has two cotyledons.

The polycotyledonous seed is one whose embryo has more than two cotyledons.

The petalous flower is one which has the corolla.

The apetalous flower is one which wants the corolla.

The dialypetalous flower is one whose corolla is dialypetalous.

The gamopetalous flover is one whose corolla is gamopetalous.

The free dialypetalous flower is one whose corolla is not united with its calyx.

The adherent dialypetalous flower is one whose corolla is more or less united with its calyx.

The free dialypetalous flower is said to be regular when its floral envelopes are regular.

The free dialypetalous flower is said to be irregular when its floral envelopes are irregular.

The adherent dialypetalous flower is said to be regular when its floral envelopes are irregular.

The adherent dialypetalous flower is said to be irregular when its floral envelopes are irregular.

The epigynous gamopetalous flower is one whose calyx-tube is adherent to the ovary.

The hypogynous gamopetalous flower is one whose calyx is free from the ovary.

The epigynous gamopetalous flower is said to be regular when its floral envelopes are regular.

The epigynous gamopetalous flower is said to be irregular when its floral envelopes are irregular.

The hypogynous gamopetalous flower is said to be regular when its floral envelopes are regular.

The bypogynous gamopetalous flower is said to be irregular when its floral envelopes are irregular.

The monochlamydeous flower is an apetalous one which has the calyx.

The achlamydeous flower is an apetalous one which wants the calyx.

The bisexual flower is one which has both the androecium and the gynocium. 
The unisexual fower is one which has but one essential organ.

The neutral flower is one without any essential organ

Bracts are said to be scattered when they are singly disposed.

Bracts are said to be verticillate when they are disposed in whorls.

The term inflorescence denotes the arrangement of the flowers upon the floral axis.

The indefinite infloreseence is one in which the lowermost flower expands first.

The definite inflorescence is one in which the terminal flower expands first.

The indefinite inflorescence is said to be ascending when the flowers are developed on an elongated floral axis.

The indefinite inflorescence is said to be centripetal when the flowers are developed on the top of a shortened flornl axis.

The raceme is an ascending inflorescence with pedicellate flowers.

The spike is an ascending inflorescence with sessile or very short pedicellate flowers.

The umbel is a centripetal inflorescence with pedicellate flowers.

The capitulum is a centripetal inflorescence with sessile flowers.

The solitary inflorescence is a definite one with but one terminal flower.

The pleiochasial cyme is a general name applied to a definite inflorescence in which the terminal flower expands first.

The false raceme is a definite inflorescence arranged like w raceme in which the true terminal flower is disposed lowermost.

Spores are minute globular bodies somewhat corresponding to seeds.

The spore-bearing leaf with one function is that which is only related to the formation of spores.

The spore-bearing leaf with two functions is that which performs the action of a foliage leaf besides the formation of spores.

\section{CHAPTER IV.}

\section{THE BUD.}

In the youngest portion of a stem, the internodes are not elongated and the leaves are folded together so as to cover the stem; such a group, that is, the youngest portion covered with rudimentary leaves, is called a $B u d$. 


\section{Section 1. KINDS OF THE BUD.}

The bud varies according to its position, function, and structure, so that it may be classified in three ways.

\section{KINDS OF THE BUD ACCORDING TO I'TS POSITION.}

The bud is developed either at the end of a stem, or Fra. 107.

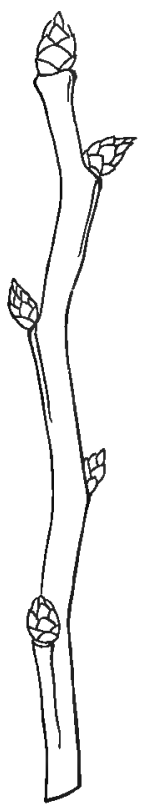

Fre. 107.-Shoot of the Sakura, showinglateral buds and a terminal one. laterally upon a stem, root, or leaf; the former kind is said to be Terminal, and the latter, Lateral. (See Fig. 107.)

KINDS OF THE BUD ACCORDING $\left\{\begin{array}{l}\text { Terminal Bud. } \\ \text { Lateral Bud. }\end{array}\right.$ TO ITS POSITION

The terminal buds and those lateral ones, which are developed regularly in the axil of a leaf (as in all the flowering plants), or immediately below or by the side of a leaf (as in many flowerless plants), are said to be Normal. (See Fig. 107.) Those lateral buds, which are developed irregularly on older parts of stems, roots, or leaves, are said to be Adventitious.

\section{KINDS OF T'HE BUD ACCORDING} TO ITSS FUNCTION.

According to its function, the bud is either Vegetative or Reproductive.

As the vegetative bud produces foliageleaves, it is also called the Leaf-bud. Some reproductive buds produce flowers; while others, as the globular buds of the Yamanoimo (Dioscorea japonica) and Tsukuimo (D. Batatas) (Fig. 108), or the bulb-like buds of the Oniyuri and Yamayuri, reproduce new plants when they fall to the ground. Those of the former 
kind are called Flower-buds, and those of the latter Fleshy Buds.

FIG. 108.

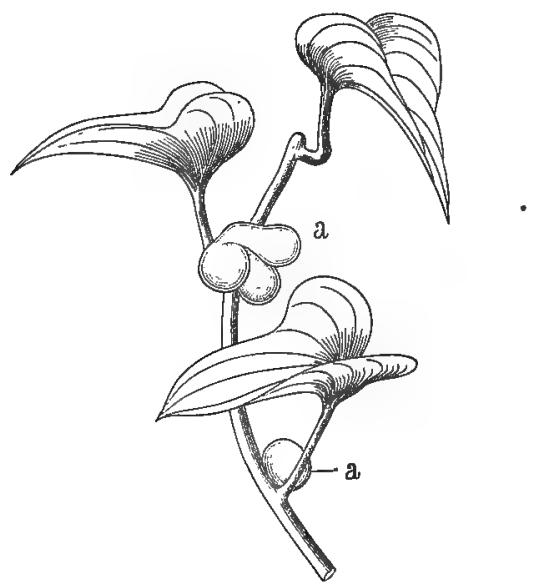

FIg. 108.-Shoot of the Tsukuimo (Dioscorea Batatas), showing fleshy buds (a).

KINDS OF THE BUD ACCORDING
TO ITS FUNCTION $\left\{\begin{array}{l}\text { Vegetative Bud-Foliage Bud. } \\ \text { Reproductive Bud }\end{array}\right.$

3. KINDS OF THE BUD ACCORDING TO ITS STRUCTURE.

Some buds are protected by special scales (Bud-scales), as in most trees; while others are not protected by such organs, as in annual herbs. Those of the former kind are said to be Scaly, and those of the latter Naked.

KINDS OF THE BUD ACCORDING
TO ITS STRUCTURE $\left\{\begin{array}{l}\text { Scaly Bud. } \\ \text { Naked Bud. }\end{array}\right.$

Section 2. THE PRAEFOLIATION OR VERNATION.

The arrangement of rudimentary leaves in the bud is called the Prafoliation; that of each separate leaf con- 
sidered independently is the Independent Profoliation; and that of the leaves in relation to each other is the Relative Prafoliation.

\section{Prafarolation $\left\{\begin{array}{l}\text { Independent Præfoliation. } \\ \text { Relative Præfoliation. }\end{array}\right.$}

As regards the independent præfoliation the leaves are either Flat as in the Akamatsu and Momi (Abies firma), Folded as ịn the Mokuren and Momiji, or Rolled as in the Hasu and Warabi.

$$
\text { InDEPENDENT PRÆfFoliation }\left\{\begin{array}{l}
\text { Flat Præf. } \\
\text { Folded Præf. } \\
\text { Rolled Præf. }
\end{array}\right.
$$

As regards the relative præfoliation, the margins of contiguous leaves either touch without overlapping, as the sepals of the Senninso (Clematis paniculata) and Kazakuruma (C. patens), or overlap one another, as the petals of the Fuji and Tsubaki. In the former case the relative præfoliation is said to be Valvate, and in the latter Imbricate.

$$
\text { Redative PRäFoliation }\left\{\begin{array}{l}
\text { Valvate Præf. } \\
\text { Imbricate Præf. }
\end{array}\right.
$$

Different kinds of præfoliation are represented in the following table.

$$
\text { PR\&FOLIATION } \begin{cases}\text { Independent Præf. } & \left\{\begin{array}{l}
\text { Flat Præf. } \\
\text { Folded Præf. } \\
\text { Rolled Præf. }
\end{array}\right. \\
\text { Relative Præf. } \ldots & \left\{\begin{array}{l}
\text { Valvate Præf. } \\
\text { Imbricate Prf. }
\end{array}\right.\end{cases}
$$

\section{SUMMARY.}

The bud is an incipient stem with its rudimentary leaves.

The terminal bud is one which is developed at the end of a stem.

The lateral bud is one which is developed laterally upon a stem, root, or leaf. 
The vegetative bud is one which produces foliage-leaves.

The reproductive bud is one which is related to reproduction.

The flover-bud is one which produces floral leaves.

The fleshy bud is one which becomes an independent plant when it falls to the ground.

The scaly but is one which is protected by special scales.

The naked bud is one which is not protected by special scales.

The prafoliation is the arrangement of leaves in the bud.

The independent prefoliation is the arrangement of each separate leaf in the bud.

The relative profoliation is the arrangement of leaves in relation to each other in the bud.

The independent prafoliation is said to be flat when the leaves are not folded in the bud.

The independent præfoliation is said to be folded when the leaves are doubled or several times bent.

The independent præfoliation is said to be rolled when the leaves are coiled in various ways.

The relative præfoliation is said to be valvate when the margins of contiguous leaves touch without overlapping.

The relative præfoliation is said to be imbricate when the margins of contiguous leaves overlap one another.

\section{CHAPTER V.}

HAIRS.

The Hairs are the protuberances developed from the outermost surface or epidermis of any part of the plant.

\section{Section 1. KINDS OF HAIRS.}

Some hairs secrete fluid-substances, as those on the young branches of the Chōshin (Rosa indica) (Fịg. 109.a) and Tabako; while others do not secrete any substances, as those on the seeds of the Wata (Gossypium herbaceum) 
FIG. 109.

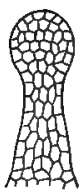

2

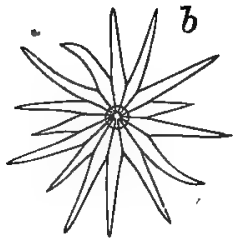

FIG. 109.-a. Glandular hair of the Chōshin (Rosa indica). Magnified.

b. Scaly hair of the Akigumi (Elceagnus umbellata). Magnified.

and Shidareyanagi. Those of the former kind are said to be Glandular, and those of the latter Eglandular.

$$
\text { HaIRS }\left\{\begin{array}{l}
\text { Glandular Hairs. } \\
\text { Eglandular Hairs. }
\end{array}\right.
$$

Some eglandular hairs are flattened, as those on the stems and leaves of the Akigumi (Elaagnus umbellata) (Fig. 109.b) and Shishigashira (Fig. 106); while others are more or less filiform or needle-shaped, as those on the seeds of the Wata or on the stems of the Tonasu. Those of the former kind are called Scales or Scaly Hairs, and those of the latter Normal Hairs.

\section{EGLANDULAR HAIRS $\left\{\begin{array}{l}\text { Scaly Hairs. } \\ \text { Normal Hairs. }\end{array}\right.$}

Among normal hairs, some are developed on roots (see Fig. 8), and others on stems or leaves (see Fig. 5). Those of the former kind are called Root Hairs, and those of the latter Shoot Hairs.

\section{NORMAL HAIRS $\left\{\begin{array}{l}\text { Root Hairs. } \\ \text { Shoot Hairs. }\end{array}\right.$}

Different kinds of hairs are represented in the following table.

$$
\text { HAIRS }\left\{\begin{array} { l } 
{ \text { Glandular Hairs. } } \\
{ \text { Eglandular Hairs } }
\end{array} \left\{\begin{array}{l}
\text { Scaly Hairs. } \\
\text { Normal Hairs }\left\{\begin{array}{l}
\text { Root Hairs. } \\
\text { Shoot Hairs. }
\end{array}\right.
\end{array}\right.\right.
$$




\section{SUMMARY.}

Hairs are protuberances developed from the epidermis of any part. Glandular hairs are those which secrete fluid-substances.

Eglandular hairs are those which do not secrete any substances.

Scaly hairs are those which are flattened and do not secrete any substances.

Normal hairs are those which are more or less filiform and do not secrete any substances.

Root hairs are those normal ones which are dereloped on roots.

Shoot hairs are those normal ones which are developed on stems or leaves. 



\section{BOOK II. \\ HISTOLOGICAL BOTANY.}

\section{INTRODUCTION.}

All parts of all plants, although they are of various sizes and shapes, may, when examined under the microscope, be found to consist of one or more minute sac-like structures. These minute bodies are called Cells.

\section{CHAPTER I.}

\section{THF CELL.}

The Cell is the elementary organ of which the fabric of plants is constructed and is usually more or less sac-like.

Section 1. PARTS OF THE CELL.

If very thin sections are made of the white portions of the leaves of the Negi and examined under the microscope, it will be seen that they are composed of many quadrangular cells, each of which consists of a clear membrane, a layer of granular semifluid substance lying in contact with the inner surface of the latter, a small globular body imbedded in the semifluid substance, and one or more drops of watery fluid. (See Fig. 110.) The membrane is called the Cell-wall; the semifluid substance, the Protoplasm; the globular body in the latter, the Nucleus; and the watery fluid, the Cell-sap. 
When the cell is young, the protoplasm fills the whole cavity; but in the course of growth small drops of the cell-sap appear and increase gradually in number until they finally coalesce into one large mass, while the protoplasmic layer, on the contrary, becomes thinner and thinner.

Fia. 110.

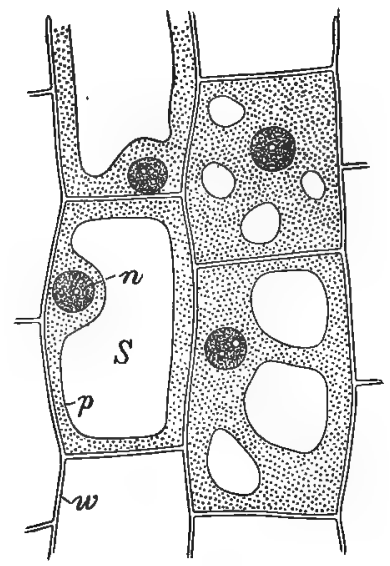

FIa. 110--Parenchymatous cells from the leaf of the Negi (Allium fistulosum). n Nucleus; p protoplasm; s cell-sap; w cell-wall.

There are some cells which are not provided with cellwalls; these are termed Primordial Cells.

$$
\text { Parts of The celL }\left\{\begin{array}{l}
\text { Cell-wall. } \\
\text { Protoplasm. } \\
\text { Nucleus. } \\
\text { Cell-sap. }
\end{array}\right.
$$

1. THE CELL-WALL.

- The Cell-wall is the outer membrane of the cell, and consists of cellulose (a carbohydrate), water, and ash-constituents. It is usually colorless and transparent. 
MARKINGS.-Sometimes the cell-wall is of uniform thickness throughout, but at other times its thickness varies at different points, so that there result several markings. In the case of isolated cells or of free cell-walls, the markings are produced on the outside of the wall, but in that of united cells they are formed on the inside. In the latter, the markings are sometimes definite; among them some result from hollows made on the internal surface of the cell-wall, and, others from prominences on the same surface.

$$
\text { MARKINGS }\left\{\begin{array}{l}
\text { Those resulting from hollows. } \\
\text { Those resulting from prominences. }
\end{array}\right.
$$

Among the markings resulting from hollows, some are caused by true perforations, and others by canals opening only at that end which is turned inwards.

$$
\begin{gathered}
\text { MAREINGS RESULTING } \\
\text { FROM HOLLOWS }
\end{gathered}\left\{\begin{array}{c}
\text { Those resulting from true perforations. } \\
\text { Those resulting from canals opening } \\
\text { only at one end. }
\end{array}\right.
$$

Even the canals opening only at one end become often completely perforated in the course of growth:

Those resulting from true perforaFIG. 111. tions are termed Sieve Markings (Fig. 111). There are some cells which have markings much resembling the above but not perforated; these are called Latticed Cells.

Among the markings resulting from canals opening only at one end, some consist of tubular canals and appear

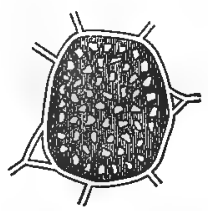

FIg. 111.-Cell with sieve marking from the stem of . the Tōnasu (Cucurbita Pepo). as bright spots when seen on the external surface; some of almost hemispherical canals widened at their base and 
perforated at their apex, and appear as two concentric circles when seen in front view; and others of transversely elongated canals closely arranged and appear like the rounds of a ladder.

Fig. 112.

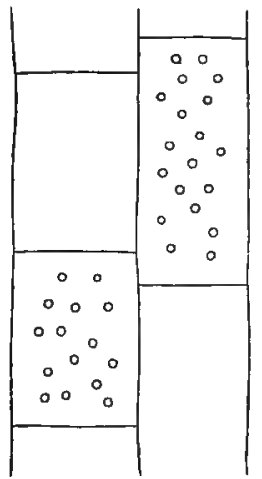

FIG. 113.

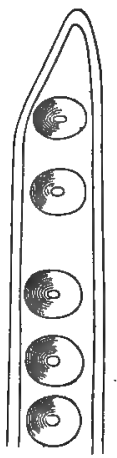

Fig. 114.

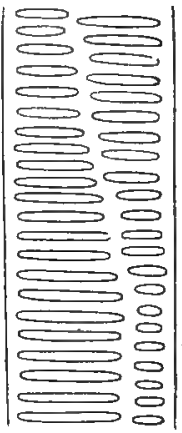

FIG. 112.-Pitted cells FIG. 113.-Cell with FIG. 114.-Cell with from the root of the bordered pits from the scalariform marking from Tenjikubotan (Dahlia variabilis). stem of the Kuromatsu (Pinus Thunbergii). the rhizome of the

Warabi

The markings of the first kind are known as Pits (Fig. 112); those of the second kind as Bordered Pits (Fig. 113); and those of the last as Scalariform Markings (Fig. 114).

$$
\begin{gathered}
\text { MARKINGS RESULTING FROM CANALS } \\
\text { OPENING ONLI A'T ONE END }
\end{gathered}\left\{\begin{array}{l}
\text { Pits. } \\
\text { Bordered Pits. } \\
\text { Scalariform Markings. }
\end{array}\right.
$$

Among the markings resulting from prominences on the inside of the cell-wall, some consist of rings extending around the internal surface; some of spirals; and others of bands united into a network. The markings of the first kind are said to be Annular (Fig. 115); those of the second kind, Spiral (Fig. 116); and those of the last, Reticulated (Fig. 117). 
FIG. 115.

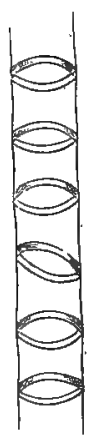

Fia. 116.

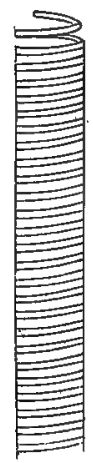

Fia. 117.

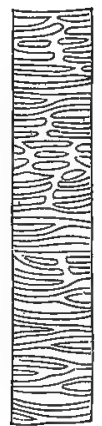

Fra. 115.-Annular Fra. 116.-Spiral Fig. 117.-Reticulated vessel from the stem of the Hōsenkwa (Impatiens Balsamina). vessel from the stem of the Hōsenkwa.

\section{MaRkINGS RESULTING FROM
PROMINENCES $\left\{\begin{array}{l}\text { Annular Markings. } \\ \text { Spiral Markings. } \\ \text { Reticulated Markings. }\end{array}\right.$}

All kinds of markings are represented in the following table.

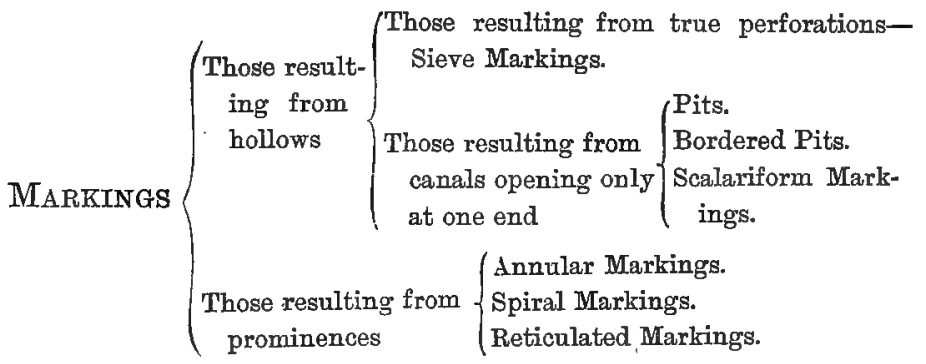

Modifications. - If a leaf of the Jinchōge or Aokiba be carefully broken, a thin transparent elastic skin may be removed from the body which can be readily found to consist of hard veins and soft green flesh. The walls of the 
cells composing the soft flesh are formed of pure cellulose; but those of the cells composing the skin are so modified that they are more extensible, highly elastic, and almost impermeable to water, and those of the hard cells among the veins are so converted that they are hard, inelastic, and are easily penetrated by water without absorbing much. When modified as in the skin, the cell-wall is said to be Cuticularized; and when modified as in the hard cells of veins, it is said to be Lignified.

Leaves of the Susuki (Miscanthus japonicus) and stems of the Tokusa (Equisetum hyemale, var. japonicum) are very hard from the deposition of the salts of silica in considerable quantity in the cell-wall. In this case the cellwall is said to be Mineralized.

All species of Corallina (Coral-like Algae) and some of Chara become very hard from the deposition of the salts of lime.

The external cell-walls of the sea-weeds, as the Kombu and Funori (Gloiopeltis coliformis), can absorb a large quantity of water and become gelatinous; such cell-walls are said to be Mucilaginous.

MODIFIED CELL-WALL $\left\{\begin{array}{l}\text { Cuticularized Cell-wall. } \\ \text { Lignified Cell-wall. } \\ \text { Mineralized Cell-wall. } \\ \text { Mucilaginous Cell-wall. }\end{array}\right.$

2. THE PROTOPLASM.

The Protoplasm consists of albuminous substances, water, and a small proportion of ash-constituents. It is usually a semifluid substance appearing more or less granular from the presence of starch grains, oil-drops, etc.; but in a few cases it appears homogeneous. As the protoplasm is the seat of all living functions it must contain 
at different times all the constituents of the organism.

Although the protoplasm is usually a semifluid substance, it sometimes assumes a solid consistence.

\section{THE CELL-SAP.}

The Cell-sap is a watery solution of various substances and usually makes a large sap-cavity within the protoplasm ; it also saturates the cell-wall and all the other organic structures of the cell.

The nature of the cell-sap varies in different cells: in some cells large quantities of cane-sugar are present, as in the stems of the Satokibi (Saccharum officinarum) or in the roots of the Tojjisa (Beta vulgaris); in some cells large quantities of grape-sugar are found, as in the fruits of the Budō and Nashi ; in some cells inulin exists, as in the roots of the Tampopo and Gobō (Lappa major); in some cells red colouring matter occurs, as in the flowers of the Tsutsuji; and in some blue colouring matter is seen, as in the flowers of the Kazaguruma (Clematis patens).

\section{Section 2. SPECIAL CONTENTS OF THE CELL.}

The cell often contains numerous other substances having definite shapes.

If thin sections of the leaves of the Tsubaki are examined under the microscope, there will be seen numerous green granules. These bodies are called Chlorophyllcorpuscles (Fig. 118).

If thin sections of the tubers of the Jagataraimo are examined under the microscope, there will be seen numerous whitish granules with concentric layers. These bodies are known as Starch-grains (Fig. 120).

If thin sections of the stems of the Shükaido are examined under the microscope, there will be seen octahedral bodies 
either scattered or aggregated.

These are Crystals (Fig. 121). of calcium oxalate.

$$
\text { SPECTAL CONTENTS OF THE CELL }\left\{\begin{array}{l}
\text { Chlorophyll-corpuseles. } \\
\text { Starch-grains. } \\
\text { Crystals, etc. }
\end{array}\right.
$$

If thin sections of oily seeds as those of the Tōgoma (Ricinus communis) and Tōnasu are examined under the microscope, there will be seen numerous rounded granules. These are only modified portions of the protoplasm and bear the name of Aleurone-grains.

In the cells of the Potato tubers, there are often found cubical bodies of albuminous matter. Although they bear a close resemblance to true crystals, they are readily distinguished from the latter by the fact that they swell up when treated with various reagents. These albuminous bodies are called Crystalloids. Crystalloids are also found within some aleurone-grains as those of the 'Tōgoma and Tōnasu.

If thin sections of the corolla of the Tampopo are examined under the microscope, numerous yellow granules will be seen.

If the root of the Ninjin is examined in the same way, orange-red rectangular plates or rhombs will be found.

\section{CHLOROPHYLL-CORPUSCLES.}

If green leaves are cut into small pieces and put in a vessel containing alcohol, the green colouring matter or Chlorophyll is readily extracted by the solvent, and the pieces become whitish. Now if thin sections of these pieces are examined under the microscope, there will be seen colourless corpuscles instead of green ones. These colourless corpuscles are specialized portions of the protoplasm. Each chlorophyll-corpuscle is therefore composed of a colourless granule of the protoplasin distributed by a small quantity of chlorophyll. The corpuscles are mostly spherical, elliptical, or ovate (Fig. 118); but in rare cases they are spiral-shaped as in Spirogyra (Fig. 119.a), star-shaped as in Zygnema (Fig. 119.b), etc. They often contain minute grantules which are the first formed starch-grains. 
Ftg. 118.
FIG. 119.

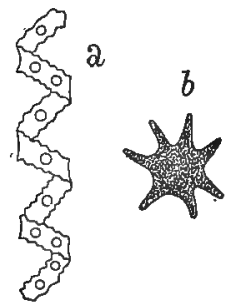

Frg. 118.-Transverse section of Fig. 119.-Chlorophyll-corpuscles.
the leaf of the Tsubali (Camellia a Spiral-shaped chlorophyll-corpuscle japonica), showing chlorophyll-cor- of a Spirogyra; b star-shaped chloropuscles. phyll-corpuscle of a Zygnema.

\section{STARCH-GRAINS.}

Starch-grains consist of starch, water, and a small proportion of ash-constituents. They have one or more central

FIG. 120.

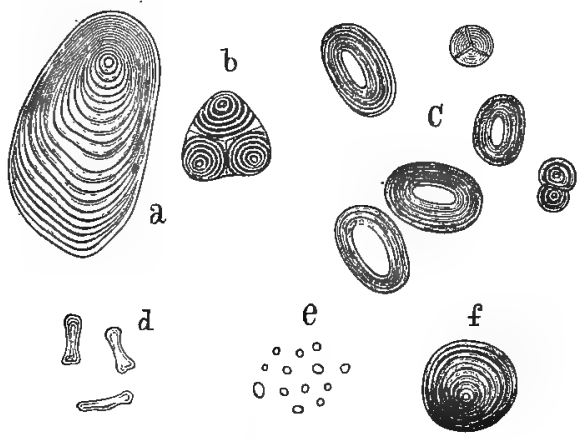

FrG. 120.-Starch grains. a Simple starch grain of the Jagataraimo; $\mathrm{b}$ compound starch grain of the same; $\mathrm{c}$ starch grains from the seed of the Fujimame (Dolichos cultratus); d starch grains of the Nishikisō ( $E u-$ phorbia humifusa); e starch grains of the Satoimo; $f$ starch grain of the Satsumaimo (Ipomaa Batatas). 
points around each of which concentric layers are disposed; those with but one centre are known as Simple (Fig. 120.a), and others with two or more central points Compound Starch-grains (Fig. 120.b).

Starch-grains vary in their sizes and shapes in different plants: thus, those of the Jagatarạimo are very large and ovate (Fig. 120.a and b); those of the Satoimo are very small and globular (Fig. 120.e); those of the Ingen and Fujimame (Dolichos cultratus) (Fig. 120.c) are large and elliptical; those of the Satsumaimo (Ipomcea Batatas) (Fig. 120.f) are large and spherical; those of the Nishikiso(Euphorbia humifusa) (Fig. 120.d) are small and boneshaped; and so on.

STARCH-GRAINS $\left\{\begin{array}{l}\text { Simple Starch-grains. } \\ \text { Compound Starch-grains. }\end{array}\right.$

\section{CRYSTALS.}

Most crystals consist of calcium oxalate, but a few of calcium carbonate.

Crystals of calcium oxalate are either octahedral as in the Shükaidō (Fig. 121.a), or prismatic as in the Hanashōbu (Iris lcevigata, var. K(empferi) (Fig. 121.c), or acerose as in the Suisen (Narcissus Tazzeta, var. chinensis) (Fig. 121.b).

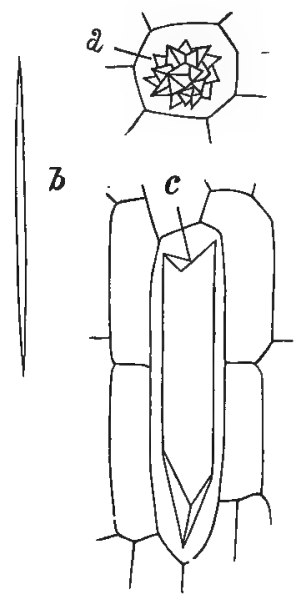

Fig. 121.-Crystal sof calcium exalate. a Cluster of octahedral crystals of the Shūkaidō; $b$ acerose crystal of the Suisen (Narcissus Tazzeta, var. chinensis); c prismatic crystal of the Hanashộbu (Irislavigata, var. Kampferi.). 


\section{Section 3. KINDS OF THE CELL.}

The form and size of the cell vary greatly, the former being spherical, elliptical, cylindrical, cubical, prismatic, star-shaped, spindle-shaped, etc., and the látter being very large as in Nitella, or very minute as in Bacteria. Longitudinal rows of cells often become tulubar by the absorption of their transverse walls.

The cells, which are not much longer than they are broad and have rounded or flattened surfaces, are said to be Parenchymatous (Fig. FIG. 122.

FIG. 123.

122) ; those, which are long, and spindleshaped, Prosenchymatous (Fig. 123); and those, which are tubular from the absorption of their transverse walls, Vascular (Fig. 115, 116 and 117).

The white central portion of the stem of the Yamabuki
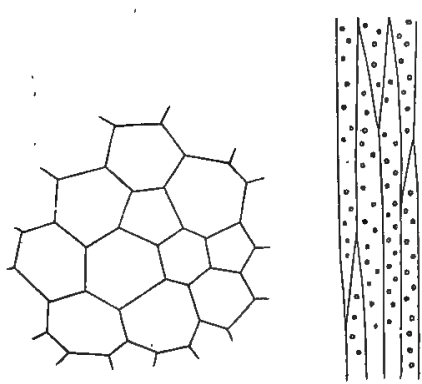

Fig. 122.-Parenchyma from the stem of the Yamabuli (Kerria japonica).

FIG. 123.-Prosenchyma from the stem of the Hōsenkwa.

(Kerria japonica) consists of parenchymatous cells; the hemp-fibres consist of prosenchymatous cells ; and the small canals in the wood of the Kiri of vascular cells.

$$
\text { KINDS OF CELLS }\left\{\begin{array}{l}
\text { Parenchymatous Cells. } \\
\text { Prosenchymatous Cells. } \\
\text { Vascular cells. }
\end{array}\right.
$$

Section 4. FORMATION OF CELLS.

The formation of cells takes place in different ways: cells may be divided into two parts by the formation of new transverse walls, each half becoming a new 
cell ; the whole or a portion of the protoplasmic contents of a mother cell may become one or more new cells; or the protoplasmic contents of two or more cells may coalesce to form a new cell.

The formation of cells as in the first case is termed the Cell-division; as in the second case, the Interior Cell-formation; and as in the last, the Conjugation. The development of vegetative organs is accomplished by cell-division; pollen-grains, spores of the Nokishinobu, Shishigashira, etc. are produced by interior cell-formation; and spores of Spirogyra, Zygnema, etc. are formed by conjugation.

$$
\text { Formation OF CELLS }\left\{\begin{array}{l}
\text { Cell-division. } \\
\text { Interior Cell-formation. } \\
\text { Conjugation. }
\end{array}\right.
$$

\section{SUMMARY.}

Cells are the elementary organs of plants and are usually more or less sac-like.

The cell-wall is the outer membrane of a cell and consists of cellulose, water, and ash-constituents.

The sieve markings of a cell-wall are those which are produced by true perforations.

The pitted markings of a cell-wall are those which are produced by numerous canals opening at one end.

The bordered pits of a cell-wall are those markings which are produced by hemispherical canals opening at the apex.

The scalariform markings of a cell-wall are those which are produced by transverse narrow canals closely disposed one above another.

The annular markings of a cell-wall are those which are produced by ringlike interior prominences.

The spiral markings of a cell-wall are those which are produced by spiral-shaped interior prominences.

The reticulated markings of a cell-wall are those whieh are produced by net-like interior prominences.

The cuticularized cell-wall is one which is so modified that it is extensible, highly elastic, and almost impermeable to water. 
The lignified cell-vall is one which is so modified that it is hard, inelastic, and is easily penetrated by water.

The mineralized cell-wall is one which is hard from the deposition of mineral matters.

The mucilaginous cell-wall is one which becomes gelatinous when it absorbs a large quantity of water.

The protoplasm is usually a semifluid substance consisting of albuminous matter, water, and a small proportion of ash-constituents.

Primordial cells are those which are destitute of cell-walls.

The cell-sap is a watery solution of various substances and usually makes a large sapcavity within the protoplasm; it also saturates the cell-wall and all the other organic structures of the cell.

The chlorophyll-corpuscle is a green body which consists of a colourless mass of the protoplasm distributed by a small quantity of a green colouring matter called chlorophyll.

The starch-grain is a minute body which has one or more central points surrounded by concentrio layers and consists of starch, water, and a small proportion of ash-constituents.

Starch-grains are said to be simple when they are provided with but one central point.

Starch-grains are said to be compound when they are provided with two or more central points.

Crystals are mostly formed of calcium oxalate and rarely of calcium carbonate.

Parenchymatous cells are those which are not much longer than they are broad and have rounded or flattened connecting surfaces.

Prosenchymatous cells are those which are long and spindle-shaped.

Vascular cells are those which are tubular from the absorption of their transverse walls.

When new cells are formed by the division of a mother cell into two parts, that mode is known as cell-division.

When one or more new cells are formed within a mother cell, that mode is known as interior cell-formation.

When a single new cell is formed by the coalescence of the protoplasmic contents of two or more cells, that mode is known as conjugation. 


\section{CHAPTER II.}

TISSUES.

Those combinations of cells, which are produced by celldivision and united to each other from the beginning of their existence, are called Tissues.

\section{Section 1. KINDS OF TISSUES.}

Each tissue may be composed either of parenchymatous cells, as in the white central portion of the stem of the Yamabuki, or of prosenchymatous cells with overlapping ends, as in the hemp-fibres, or of vascular cells, as in the minute canals in the wood of the Kiri. In the first case, the tissue is known as Parenchyma (see Fig. 122); in the second, as Prosenchyma (see Fig. 123); and in the last, as Vascular Tissue.

$$
\text { KINDS OF TISSUES }\left\{\begin{array}{l}
\text { Parenchyma. } \\
\text { Prosenchyma. } \\
\text { Vascular Tissue. }
\end{array}\right.
$$

The parenchyma may consist of soft parenchymatous cells, as in the white central portion of the stem of the 'Yamabuki, or of hard thick-walled parenchymatous cells, as in the grit of Pears. The former kind may be called the Soft Parenchyma, and the latter the Hard Parenchyma.

$$
\text { PARENCHYMA }\left\{\begin{array}{l}
\text { Soft Parenchyma. } \\
\text { Hard Parenchyma. }
\end{array}\right.
$$

There is still another kind of parenchyma, which is composed of those cells that are long and mostly prismatic with their walls thickened along the longitudinal angles. It is known as Collenchyma and is found in the stems of many plants, as the Tōnasu, Shükaidō, etc.

The prosenchyma may consist of soft flexible prosenchymatous cells, as in the hemp-fibres, or of hard lignified 
prosenchymatous cells, as in the wood of the Alkamatsu ; the former kind is called the Bast Prosenchyma, and the latter the Woody Prosenchyma.

$$
\text { Prosenchyma }\left\{\begin{array}{l}
\text { Bast Prosenchyma. } \\
\text { Woody Prosenchyma. }
\end{array}\right.
$$

'The vascular tissue may consist of soft vascular cells, as in the inner bark of Dicotyledonous Plants, or of hard vascular cells, as in the wood of common trees; the former are called Bast Vessels, and the latter Woody Vessels or Trachea.

$$
\text { VASCULAR TISSUE }\left\{\begin{array}{l}
\text { Bast Vessels. } \\
\text { Woody Vessels. }
\end{array}\right.
$$

As the bast vessels have thick transverse walls with numerous closelyset perforations (sieve markings), they are also known as Sieve-vessels or Sieve-tubes. These vessels are filled with protoplasmic contents, and the woody vessels with air or water.

There is another kind of vessels containing a milky or coloured fluid as in the Tampopo; they are called Laticiferous Vessels.

All the kinds of tissues are represented in the following table.

$$
\text { KINDS OF TIISSUES }\left\{\begin{array}{l}
\text { Parenchyma..... }\left\{\begin{array}{l}
\text { Soft Parenchyma. } \\
\text { Hard Parenchyma. } \\
\text { Prosenchyma.... } \\
\text { Bast Prosenchyma. } \\
\text { Woody Prosenchyma. } \\
\text { Vascular tissue. }
\end{array}\right. \text { Bast Vessels. } \\
\text { Woody Vessels. }
\end{array}\right.
$$

\section{Section 2. TISSUE-SYSTEMS.}

The lowest multicellular plants are composed of uniform tissues, but in the highest ones their bodies are composed of different tissues which are regularly arranged in particular ways in each plant. Each aggregation of elementary tissues forming a definite portion of the plant-body is called a Tissue-system. 


\section{KINDS OF TISSUE-SYSTEMS.}

If the petiole of the Ōbako be broken across, tough bundles will be observed, and a thin transparent skin may be easily stripped off from its surface. These bundles are chiefly composed of vessels and prosenchyma, and are called Fibro-vascular Bundles. They traverse the plant-body and form the Fibro-vascular System. The thin skin covering the plant-body is called the Epidernal System. That group of tissues which is situated within the latter and encloses the fibro-vascular bundles, is termed the Fundamental System.

$$
\text { KINDS OF TISSUE-SYSTEMS }\left\{\begin{array}{l}
\text { Fundamental System. } \\
\text { Fibro-vascular System. } \\
\text { Epidermal System. }
\end{array}\right.
$$

The Fundamental System.-This system consists principally of parenchyma from which all the other tissues are derived.

The Fibro-vascular Srstem.-This system consists of prosenchyma, vessels, and a few parenchymatous cells, arranged in bundles which run longitudinally through the plant-body.

Parts of the Fibro-vasctlar Bundle.-Each fibrovascular bundle is composed of two portions, an inner and an outer. The inner portion is hard when well developed and consists of woody vessels, woody prosenchyma, and hard parenchyma; and the outer is comparatively soft and eonsists of bast vessels, bast prosenchyma, and soft parenchyma.

The former portion is called the Xylen or Wood, and the latter the Phlö̈n or Bast.

PARTS OF THE FIBRo-vasctLAR BUNDLE $\left\{\begin{array}{l}\text { Xylem. } \\ \text { Phloöm. }\end{array}\right.$ 
Kinds of Fibro-vascular Bundles.-Some fibro-vascular bundles possess a layer of generating tissue called the Cambium between the xylem and the phloëm, as in the stems of the Sakura and Akamatsu; while others want the cambium, as in the Oniyuri and Nokishinobu. Those of the former kind increase the bulk of the xylem and of the phloëm by the growth of cambial cells, and are said to be Open; and those of the latter are incapable of any further growth, and are said to be Closed.

\section{KINDS OF FIBRO-VASCULAR BUNDLES IN REGARD TO THEIR GROWTH Closed Fibro-vascular Bundles.}

The EprdermaL System.-This system consists of more or less modified parenchyma.

Parts OF THE EPIDERFIg. 124. MAL SrsteM.-When well developed, this system is composed of a membrane, consisting of one or more layers of parenchymatous cells, perforated by numerous openings, and provided with various pro-

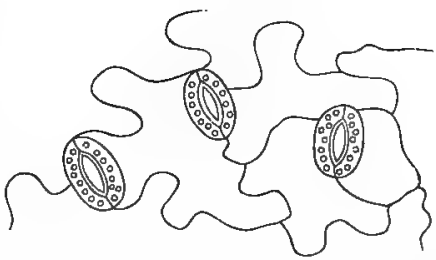

Frg. 124.--Epidermis of the leaf of the Kabura, showing stomata.

tuberances. The membrane is called the Epidermis; the openings through the latter, Stomata (Fig. 124); and the protuberances on the surface, Hairs.

The epidermis consists of those cells which are in close juxtaposition without any intercellular spaces except at the points where it is perforated by the stomata. (See Fig. 118.) The upper cell-walls of the epidermis are usually cuticularized and are rendered impermeable to water; but in submersed or very young parts the epidermal cells are not 
cuticularized. When roots or stems grow much in thickness, the epidermis is usually ruptured and a new skin is formed from the cortical fundamental tissue.

\section{SUMMARY.}

Tissues are those combinations of cells which are produced by celldivision and united to each other from the beginning of their existence.

The parenchyma is a tissue composed of parenchymatous cells.

The prosenchyma is a tissue composed of prosenchymatous cells.

The vascular tissue is one composed of vascular cells.

The soft parenchyma is a tissue composed of soft parenchymatous cells.

The hard parenchyma is a tissue composed of hard parenchymatous cells.

The bast prosenchyma is a tissue composed of soft flexible prosenchymatous cells.

The woody prosenchyma is a tissue composed of hard lignified prosenchymatous cells.

Bast vessels are those composed of soft vascular cells.

Woody vessels are those composed of hard vascular cells.

Tissue-systems are aggregations of elementary tissues forming a definite portion of the plant-body.

The epidermal system forms the outer skin of the plant-body.

'l'he epidermis is a membrane consisting of one or more layers of parenchymatous cells.

Stomata are the openings through the epidermis.

Hairs are the protuberances on the surface of the epidermis.

The fundamental system is that group of tissues which is situated within the epidermal system and encloses the fibrovascular system.

The fibrovascular bundle is a band chiefly composed of ressels and prosenchyma.

I'he xylem is the hard portion of the fibrovascular bundle.

The phloëm is the soft portion of the fibrovascular bundle.

The fibrovascular system is composed of fibrovascular bundles. 


\section{CHAPTER III.}

\section{INTERCELLULAR SPACES.}

If the stems of Grasses are cut across, there will be found large cavities extending through whole internodes; and if thin sections of ordinary leaves are examined under the microscope, there will be seen several lacunæ between the cells of the fundamental system. All kinds of the above mentioned lacunæ are termed Intercellutar Spaces.

Section I. KINDS OF INTERCELLULAR SPACES.

Intercellular spaces vary according to their origin and contents, so that they may be classified in two ways.

1. KINDS OF INTERCELLULAR SPACES ACCORDING TO THEIR ORIGIN.

Intercellular spaces may be formed either by a splitting of the common wall of adjacent cells as in the leaves of ordinary plants, or by the rupture of certain cells as in the stems of Grasses.

KINDS OF INTERCELLULAR SPACES ACCORDING TO THEIR ORIGIN
- Those formed by a splitting of the common wall of adjacent cells.

Those formed by the rupture of certain cells.

2. KINDS OF INTERCELLULAR SPACES ACCORDING TO THEIR CONIENTS.

Intercellular spaces contain either air as in the stems of Grasses and ordinary leaves, or certain peculiar substances 
as the resin-containing lacunæ in the leaves and stems of Pines.

KINDS OF INTERCELLULAR SPACES
ACCORDING TO THEIR CONTENTS $\left\{\begin{array}{c}\text { Those containing air. } \\ \text { Those containing certain } \\ \text { peculiar substances. }\end{array}\right.$

\section{SUMMARY.}

Intercellular spaces are lacunæ between the cells of a tissue.

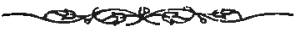




\section{BOOK III. PHYSIOLOGICAL BOTANY.}

\section{INTRODUCTION.}

For the continual existence of plants on the earth, they must first support their own lives for some time and must next reproduce their kinds.

That department relating to the maintenance of their own lives we term Physiology of Nutrition, and that relating to reproduction Physiology of Reproduction.

\section{CHAPTER I.}

\section{PHYSIOLOGY OF NUTRITION.}

In order to support their living functions, plants must constantly receive proper food and must convert this into bodily substances, because they consume contiuually the latter for the performance of every function. These functions are accomplished by the aid of several external forces such as light, temprature, etc.

\section{Section 1. NUTRITION PROPER.}

1. TRANSPIRATION.

If a tightly closed cylinder containing two or three weighed leaves of the Tönasu and a dish of dry calcic chloride of known weight be examined after exposing it to the sun for a few hours, it will be found that the leaves will 
have withered and lost much weight, and that the salt will have become moistened and much increased in weight. It is clear that what the salt has gained is the water that has. been lost by the leaves in the form of vapour. This action is known as Transpiration. It is always going on from the surface of all parts of plants which are exposed to the air; above all, leaves are the organs where the greatest loss of water takes place. In adult leaves the watery vapour is principally carried out from the stomata, which regulate transpiration to a great extent, by their opening and closing according to different circumstances.

As the cell-walls of the epidermis of submersed plants are not cuticularized, these plants wither rapidly when exposed to the air owing to the evaporation of water from their whole surfaces.

\section{RESPIRATION.}

If some living water plants as Spirogyra be put in an airtight flask filled with water made free from oxygen by boiling, they will perish after a few days.

If a flower-pot with a living plant be put in a closed vessel filled with carbonic acid gas, the plant will die after a. few days.

From the preceding experiments it will be understood that oxygen is indispensable to the life of the plant.

If a funnel filled with moist seeds of the Daidzu be inserted into the mouth of a bottle containing a solution of caustic potash, the seeds will gradually commence to germinate, the clear solution will slowly turn whitish, and a rise of temperature may be observed in the germinating seeds.

In the above experiment the potash solution is turned whitish by absorbing the carbonic acid gas which is evolved 
by the germinating seeds, and the rise of temperature is caused by the oxidation accompanying germination.

Now it will be seen that plants, like animals, take up oxygen and give off carbonic acid as long as they live, and this process is Respiration. In this process heat is always set free in plants as it is in the case of animals; but in plants as the process of heat-production is feeble and other conditions lead to rapid cooling, the rise of temperature is usually insignificant.

\section{3. $A B S O R P T T O N$.}

If a flower-pot with a living plant be exposed to the sum without being watered, the plant will begin to droop and wither after a few days. Now if a sufficient quantity of water be given to the plant, it will gradually regain its healthy condition.

If some living land plants with their roots immersed in pure distilled water be kept for a long time, they will gradually become unhealthy and will finally perish.

From the preceding experiments it will be found that plants must absorb water and several other substances for the maintenance of their vitality. It is known from several experiments that the food of plants consists of water, soluble salts, oxygen, and carbonic acid.

Water and soluble salts are absorbed by young roots and root-hairs, oxygen by all living parts, and carbonic acid by all green organs of which leaves are the chief.

Submersed plants may absorb nutritious substances through their whole surfaces.

Some insoluble substances as marble are decomposed by the acid sap, which saturates the cell-walls of the root, and are brought into solution. 


\section{CONSTIIUENTS OF THE PLANT-FOOD.}

It has been discovered by water culture, which consists in growing plants with their roots immersed in water holding known substances in solution, and analysis, that the elements which are essential to the life of plants are Carbon, Hydrogen, Oxygen, Nitrogen, Sulphur, Phosphorus, Potassium, Calcium, Magnesium, and Iron.

Carbon, which is an essential constituent of organic compounds, is absorbed by green plants in combination in the form of the carbonic acid which is found in a small quantity in the atmosphere.

Hydrogen, which is a constituent of every organic compound, is absorbed by all plants in combination usually in the form of water.

Oxygen, which is a constituent of some organic compounds, is absorbed by plants either free, or in combination in the form of water or of salts.

Nitrogen, which is an essential constituent of albuminous substances, is absorbed by plants in combination in the form of nitrates or of compounds of ammonia.

Sulphur, which is a constituent of albuminous substances, Mustard oil, etc., is taken up by plants in the form of sulphates.

Phosphorus, which is a constituent of some organic compounds, is derived from phosphates. It is said that this element bears an important relation to certain metabolic processes of plants.

Potassium, which bears a very important relation to the function of chlorophyll and to the storing-up of carbohydrates, is derived from its salts.

Calcium and Magnesium, which are both important for the normal development of plants, are derived from their salts. 
Iron, which is absolutely necessary for the formation of chlorophyll, is derived from its different compounds.

Besides the above mentioned elements, Chtorine, which is derived from chlorides, is necessary to the normal development of some plants, as the Soba (Fagopyrum esculentum); and Silicon, which is taken up by plants in the form of silicates or silicic acid, is important in some plants, as the Take, in giving firmness and rigidity to their tissues.

In order to prepare a solution for water-culture, one of the following groups of chemical compounds may be taken.

1.

Distilled water,

Potassium nitrate,

Calcium sulphate, Magnesium sulphate, Magnesium sulphate, Calcium phosphate, Ferrous sulphate.

2.

Distilled water,

Potassium nitrate, Calcium nitrate, Ferrous phosphate,
Potassium superphosphate, Calcium nitrate, Sodium chloride.
3.

Distilled water, Potassium sulphate, Magnesium phosphate. Ammonium nitrate, Ferrous chloride.

5. THE MIOVEMENT OF WATER AND SUBSTANCES IN SOLUTION ABSORBED BY THE ROOT.

If a living branch of the Sakusa be cut off and put into a vessel containing a solution of anilin-violet, it will be seen that the colouring-matter rises through the xylem with the water.

If the bark of the Salkura be cut away in the form of a ring around the circumference, the leaves will not wither.

If the stem of the Hechima (Luffa Petola) be cut off ten or more inches above the ground, watery fluid will flow out from the cut surface of that portion of the stem which is connected with the root.

From the first and second experiments it will be known that water and substances in solution absorbed by the root are conveyed upward passing through the xylem, in which 
the cell-walls are lignified and made to be easily pewetrated by water.

From the last experiment it will be seen that the root. has itself the function of carrying up the water it has. absorbed. This action is called the Root-pressure.

As the leaves lose continually water by transpiration, the water absorbed by the root ascends towards them to compensate for the loss; and in the growing portion a fresh supply of water is necessary, and a sufficient quantity is conveyed towards it.

The movement of water is therefore caused by three distinct actions, namely : the root-pressure; transpiration; and growth.

\section{THE MOVEMEN' OF GASES.}

In the plant-body, the gases dissolved in water are conveyed by it to the point which is relatively poor in them; and the gases in the intercellular spaces move freely, and communicate with the outer air by means of the stomata.

\section{ASSIMILATIION.}

If a water plant as the Sasamo be placed in a glass vessel containing water, which holds carbonic acid in solution, be covered by an inverted glass funnel, whose narrow portion is again covered by an inverted test tube filled with water, and be exposed to sumshine, it will be seen that bubbles of gas are given off from the plant and accumulate witbin the test tube. If the accumulated gas be tested, it will be found to consist of oxygen.

If water, which does not hold carbonic acid in solution, be used in the above experiment, no bubbles of oxygen gas will be given off.

If green leaves are cut off from the stem during the day 
and thin sections of them are examined under the microscope, there will be seen minute starch grains in each chlorophyll-corpuscle.

If green leaves are cut off from the stern during the night and are examined in the same way, there will be found no starch grains in chlorophyll-corpuscles.

From the first experiment it will be seen that green leaves absorb carbonic acid, decompose it by the help of light; and evolve oxygen.

From the second experiment it will be understood that the bubbles of oxygen gas can not be given off without a fresh supply of carbonic acid.

From the third and fourth experiments it will be known that starch grains are formed only during the day in chlorophyll-corpuscles.

Now, from the preceding experiments it is clear that chlorophyll-corpuscles absorb carbonic acid, decompose it by the help of light, give off part of its oxygen, and produce starch grains by combining the residue with the elements of water. 'Starch grains are indeed the first organic compounds that can be detected under the microscope. This process of the formation of starch grains in chlorophyllcorpuscles is known as Assimilation.

\section{CONSTRUCTIVE METABOLISM.}

Starch grains produced in chlorophyll-corpuscles are constantly converted into sugar and removed from the corpuscles; the sugar thus formed may be used up for the formation of cellulose, or albuminous matter combining with other substances, or may be reconverted into starch grains which are stored in different organs for future use.

In short, starch grains formed in chlorophyll-corpuscles 
are sources of all the other organic substances of plants, and even the tissues of animals are either directly or indirectly derived from them.

\section{DESTRUCTIVE METABOLISM.}

During the construction of new tissues several compounds are formed as by-products. These are Tannin, Organic Acids, Colouring Matters, Alkaloids, Volatile Oils, etc.

Old tissues are aften changed into such substances as Gum Arabic, Cherry Gum, etc. These are the products of degradation which can undergo no further modification in plants.

In the processes of all vital functions, decomposition is an inevitable occurrence, and the evolution of carbonic acid is the result.

\section{EXCRETION.}

In plants, even waste products which are entirely useless to them are mostly retained in their tissues, and only small portions are excreted. The chief excreta of common green plants are all given off in the gaseous form: they are oxygen, carbonic acid, and watery vapour.

Although the majority of waste products are retained in plants, they are gradually got rid of by the detachment of the bark, fruits, etc., in which they are abundantly deposited.

\section{Section 2. EXTERNAL FORCES.}

1. TEMPERATURE.

If an herbaceous plant as the Kabura be boiled in water, the plant body will become gradually softened and will be finally killed. 
If an herbaceous plant as the Satoimo be frozen and be quickly thawed, its vitality will be generally destroyed.

From the preceding experiments it will be seen that common plants can live only within certain limits of temperature. From several experiments it has been assumed that the vital processes of common plants begin at a certain number of degrees above freezing-point and cease at about $50^{\circ} \mathrm{C}$. ; and that the most favourable conditions of vital activity are generally attained at temperatures from about $25^{\circ}$ to $30^{\circ} \mathrm{C}$.

\section{LIGH'T.}

If the stems of the Udo (Aratia cordata) be covered with soil, they will become whitish after several days.

If the seeds of the Daidzu be germinated in complete darkness, the young plants produced will assume a whitish colour.

If the same seeds be germinated in places fully exposed to light, the young plants produced will assume a green colour.

From the preceding experiments it is clear that the formation of chlorophyll is dependent upon light.

The formation of starch in chlorophyll corpuscles, as has been seen, is also dependent upon light.

light is therefore indispensable to green plants.

In regard to growth, many organs are considerably retarded by light; the stems of many plants are caused by this influence to decline towards the sun.

\section{GRAVITATION.}

If a young plant as the Daidzu planted in a flower-pot be inverted, the apex of the stem will be gradually directed upward and the apex of the root downward. 
From the above experiment it will be seen that the root obeys the force of gravitation, while the stem opposes this force.

Gravitation is therefore a force which determines the direction of growing parts.

\section{FLECTRICITY.}

Plauts are good conductors of electricity and equalise the difference of the electric tension of earth and air ; large trees are therefore often struck by lightning.

Besides the above mentioned forces, wind, various living beings, and others also exercise much influence on plants. Thus, wind may wodirfy the direction of the stem, may disperse fruits and seeds to distant places, may carry the pollen grains of one flower to another, and may perform other actions; and other living beings may disperse fruits and seeds to distant places, may carry pollen-grains, may become the hosts of parasitic plants, and may do other actions.

\section{Section 3. GROWTH.}

Growth is brought about by internal processes which enlarge and alter permanently any portion of plants.

A sufficient quantity of raw material and water is first indispensable to growth; and proper temperature is next important.

In the process of growth, new cells are first formed by repeated cell-division; these new cells are next enlarged in size; and they are variously modified in the last. The first stage may be termed Growing; the second stage, Elongating ; and the last, Fully-developed.

\section{Section 4. IRRITABILITY.}

If the leaves of the Nemurigusa (Mimosa pudica) be touched by a foreign body, their leaflets will be immediately 
drawn together and their main petioles will suddenly bend downward.

If the same plant be observed during the night, it will be seen that its leaves take just the same form as in the case when touched by a foreign body.

This sensitiveness to the action of various external stimuli is known as Irritability.

\section{THE IRRITABILITY OF YOUNG ORGANS.}

The organs of plants are most sensitive in their elongating stage to various external stimuli. Thus, young tendrils are soon caused to curve by a slight touch; and young stems may soon incline towards sunshine

\section{THE LRRTIABLLILY OF MATURE ORGANS.}

Fully-developed organs are. mostly much weakened in their irritability, but a few organs of some plants can perform movements even after they are fully matured. Thus, the leaves of the Nemurigusa change their position day and night, and also when touched; the stamens of the Megi move quickly when they are touched; and the hair-like appendages on the leaves of the Müsengoke curve inwards when touched by a foreign body.

\section{SUMMARY.}

Nutrition is a general term for all the processes of absorption, respiration, transpiration, assimilation, and metabolism.

Iranspiration is a process of evaporating water from the surface of the plant-body.

Respiration is a process of absorbing oxygen and evolvlng carbonic acid. Absorption is a process of diffusing water and substances in solution through the cell-walls of the epidermis into the interior of the plant-body.

Assimilation is a process in which starch grains are formed in chlorophyll-corpuscles.

Metabolism is a general name for all the processes accompanying the construction and the destruction of various tissues. 
Growth is a general term for all the processes relating to the permanent enlargement and alterations of various organs.

Irritability is a term denoting the sensitiveness of any organ to the action of externar stimuli.

\section{CHAPTER II.}

\section{PHYSIOLOGY OF REPRODUCTION.}

Some plants, as the Mume, Daidzu, and Ine, usually reproduce their kinds by seeds; while other plants, as the Jagataraimo and Satoimo, usually reproduce their kinds by separating their subterranean stems. The former process is termed the True Reproduction, and the latter the Vegetative Reproduction.

\section{SUMMARY.}

True reproduction is a process in wich plants are reproduced by seeds.

Vegetative reproduction is a process in which plants are multiplied by the separation of their own parts. 


\section{BOOK IV.}

\section{SYSTEMATIC BOTANY.}

\section{INTRODUCTION.}

Some plants, as the Sakura, Ine, and Akamatsu, produce flowers; while others, as the Warabi, Sugigoke (Polytrichum commune), and Kombu, do not produce them. Those of the former kind are termed Flowering Plants or Phanerogama, and those of the latter Flowerless Plants or Cryptogama.

Notwithstanding the vast number of species of plants, they all are either Phanerogame or Cryptogama.

Plants $\left\{\begin{array}{l}\text { Phanerogamæ. } \\ \text { Cryptogamæ. }\end{array}\right.$

\section{CHAPTER I.}

\section{PHANEROGAM 开.}

In some Phanerogamæ, as the Sakura (Fig. 55) and Ingen (Fig. 76), the ovules are enclosed in an ovary; while in others, as the Akamatsu and Sugi, they are naked having no ovary. The former we term Angiosperma, the latter Gymnosperma.

Phanerogamæ are thus divided into the two groups Angiosperme and Gymnosperma.

Phanerogam $\left\{\begin{array}{l}\text { Group I. Angiospermæ. } \\ \text { Group II. Gymnospermæ. }\end{array}\right.$ 
F1G. 125

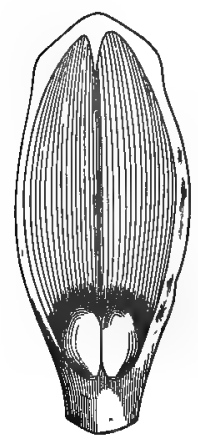

Fia. 125.-Carpellary scale with two seeds from a ripe cone of the Akamatsu:

\section{Group I. ANGIOSPERM E.}

Some plants of this group, as the Daidzu and Asagao (Fig. 90) have dicotyledonous seeds; while others, as the Ine and Ōmugi (Fig. 89), have monocotyledonous seeds. Those of the former kind are called Dicotylece, and those of the latter Monocotylece.

Angiospermæ are thus divided into the two classes Dicotylece and Monocotyler.

$$
\text { ANGIOSPERM } 2 \text { E }\left\{\begin{array}{l}
\text { Class I. Dicotyleæ. } \\
\text { Class II. Monocotyleæ. }
\end{array}\right.
$$

In the plants belonging to Dicotylex and Gymnospermæ, the stem is provided with open fibrovascular bundles arranged in circles. If the stem of a Sakura which is several years old be transversely cut, numerous concentric layers will be seen in the xylem. These layers are termed Annual Rings. They result from the fact that the cells formed in the spring have a much larger radial diameter than those formed in the autumn.

In the stems of Monocotyleæ and Cryptogamæ, the fibrovascular bundles are irregularly arranged. 


\section{Class I. DICOTYLEAE.}

Some plants of this class, as the Kimpōge and Sakura, have dialypetalous flowers; some, as the Kikyo and Asagao, gamopetalous flowers; and others, as the Jinchōge and Shidareyanagi, apetalous flowers. Those of the first kind are called Dialypetalc; those of the second kind, Gamopetalce; and those of the last, Apetalce.

Dicotyleæ are thus divided into the three subclasses Dialypetalæ, Gamopetalæ, and Apetalæ.

$$
\text { DicotXLe } \approx\left\{\begin{array}{l}
\text { Subclass I. Dialypetalæ. } \\
\text { Subclass II. Gamopetalæ. } \\
\text { Subclass III. Apetalæ. }
\end{array}\right.
$$

\section{Subclass I. DIALYPETAL $\approx$.}

Some plants of this subclass, as the Kimpoge and Kabura (Fig. 54), have free dialypetalous flowers; while others, as the Sakura (Fig. 55) and Fuji, have adherent dialypetalous flowers. The former we term Thalamiflorce, the latter Calyciflora.

Dialypetalæ are thus divided into the two series Thalamifloræ and Calycifloræ.

$$
\text { Dralipetat } \mathbb{E}\left\{\begin{array}{l}
\text { Series I. Thalamifloræ. } \\
\text { Series II. Calycifloræ. }
\end{array}\right.
$$

Subclass II. GAMOPETAL $A$.

Some plants of this subclass, as the Hakone-utsugi (Fig. 92) and Tampopo, have epigynous gamopetalous flowers; while others, as the Asagao and Sagigoke (Fig. 93), have hypogynous gamopetalous flowers. The former we term Gamopetala Epigyna, the latter Gamopetalce Hypogyne.

Gamopetalæ are thus divided into the two series Gamopetalæ Epigynæ and Gamopetalæ Hypogynæ. 


\section{Gamopetal $\notin\left\{\begin{array}{l}\text { Series I. Gamopetalæ Epigynæ } \\ \text { Series II. Gamopetalæ Hypogynæ. }\end{array}\right.$}

\section{Subclass III. APETAL $Æ$.}

Sorne plants of this subclass, as the Tsukubane (Buckleya lanceolata) and Kan-aoi (Asarum Blumei), have epigynous. flowers ; while others, as the Jinchoge and Nawashirogumi, (Fig. 94), have hypogynous flowers.

The former we term Apetala Epigyne, the latter Apetale Hypogynce.

Apetalæ are thus divided into the two series Apetalæ Fpigynæ and Apetalæ Hypogynæ.

\section{APETAL $\left\{\begin{array}{l}\text { Series I. Apetalæ Epigynæ. } \\ \text { Series II. A Apetalæ Hypogynæ. }\end{array}\right.$}

\section{Class II. MONOCOTYLEAE.}

Some plants of this class, as the Ayame (see Fig. 69) and Oniyuri (Fig. 126), have showy flowers; while others, as the Fig, 126.

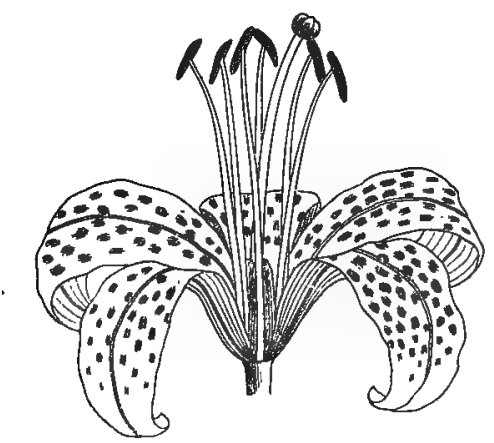

FIg. 126.-Flower of the Oniguri (Lilium tigrinum).

Shuro and Ine (Fig. 10), have only inconspicuous scaly floral envelopes or even want them. Those of the former 
kind are termed Petaloidece, and those of the latter Nudiflore.

Monocotyleæ are thus divided into the two subclasses Petaloideæ and Nudifloræ.

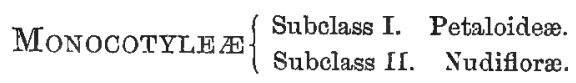

\section{Subclass I. PETALOIDEAE.}

Some plants of this subclass, as the Ayame (see Fig. 69) and Suisen, have epigynous flowers; while others, as the Oniyuri (Fig. 126) and Tsuyukusa, have hypogynous flowers. Those of the former kind are termed Petaloidece Epigynce, and those of the latter Petaloidece Hypogyna.

Petaloideæ are thus divided into the two series Petaloideæ Epigynæ and Petaloideæ Hypogynæ.

$$
\text { Petalonde } \begin{cases}\text { Series I. } & \text { Petaloideæ Epigynæ. } \\ \text { Series II. } & \text { Petaloideæ Hypogynæ. }\end{cases}
$$

\section{Subclass II. NUDIFLORA.}

Some plants of this subclass, as the Shuro and Tennanshō (Eig. 5:3), have large scattered bracts which cover clusters of flowers ; while others, as the Ine (Fig. 10) and Suge, have small scattered bracts. Those of the former kind are termed Spadiciflorce, and those of the latter Glumiflorce.

Nudifloræ are thus divided into the two series Spadicifloræ and Glumifloræ.

$$
\text { NUDIF LOR \& }\left\{\begin{array}{cc}
\text { Series I. } & \text { Spadicifloræ. } \\
\text { Series II. } & \text { Glumifloræ. }
\end{array}\right.
$$

General classification of Phanerogamæ are represented in the following table. 


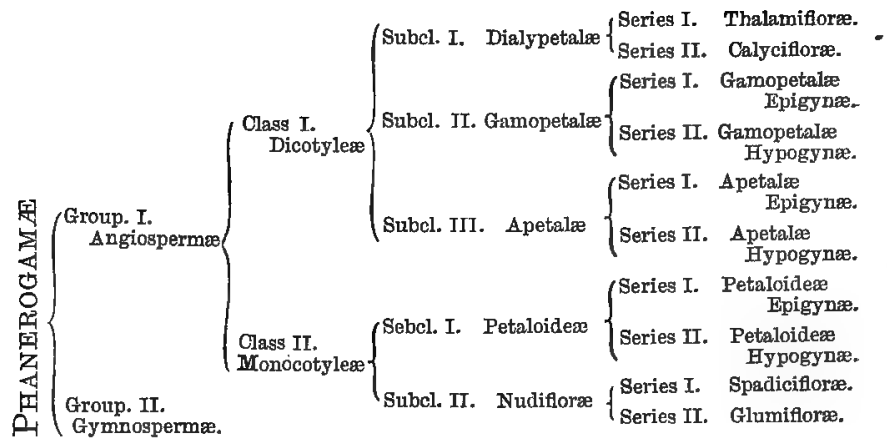

\section{CHAPTER II.}

\section{CRYPTOGAM开.}

Some Cryptogamæ, as the Warabi and Sugina (Equisetum arvense) (Fig. 128), have fibrovasculor bundles; some want fibrovascular bundles, having either a stem bearing green leaves as the Sugigoke, or a thalloid body with more or less developed epidermis as the Zenigoke; and others, as the Matsudake and Kombu, want fibrovascular bundles and true epidermis, presenting no differentiation of root, stem, and leaf. Those of the first kind are termed Pteridophyta; those of the second kind, Bryophyta; and those of the last. Thallophyta.

Cryptogamæ are thus divided into the three groups. Pteridophyta, Bryophyta, and Thallophyta.

$$
\text { Cryptogam \& } \begin{cases}\text { Group I, } & \text { Pteridophyta. } \\ \text { Group II. } & \text { Bryophyta. } \\ \text { Group III. } & \text { Thallophyta. }\end{cases}
$$




\section{Group I. PTERIDOPHYTA.}

Some plants of this group, as the Warabi and Nokishinobu (Fig. 51), have well developed large leaves; some, as the Hikagenokatsura (Lycopodium clavatum) (Fig. 127) and Iwahiba (Selaginella involvens), have small scattered

Fig. 127.

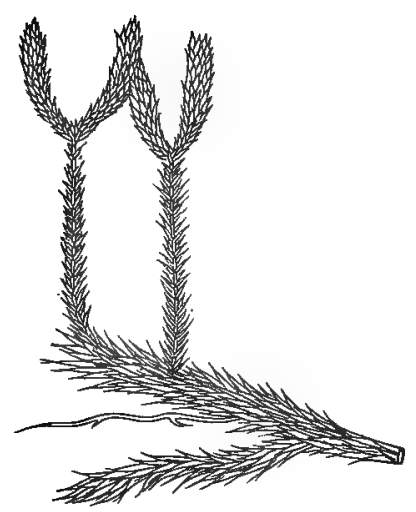

FIG. 127.-Hikagenokatsura (Lycopodium clavatum).
FIG. 128.

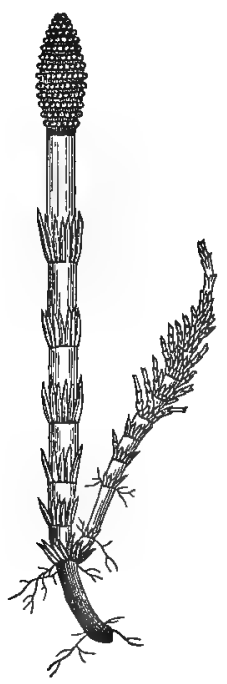

Frg. 128.-Sugina (Equisetum arvense).

leaves ; and others, as the Tokusa (Equisetum hyemale, var. japonïcum) and Sugina (Fig. 128), have minute verticillate leaves. 'Those of the first kind are termed Filicince; those of the second kind, Lycopodince; and those of the last, Equisetince.

Pteridophyta are thus divided into the three classes Filicinæ, Lycopodinæ, and Equisetinæ. 


$$
\text { PTERIDOPHYTA } \begin{cases}\text { Class I. } & \text { Filicinæ. } \\ \text { Class II. } & \text { Lycopodinæ. } \\ \text { Class III. } & \text { Equisetinæ. }\end{cases}
$$

\section{Group II. BRYOPHYTA.}

Some plants of this group, as the Sugigoke and Kosugigoke (Pogonatum) (Fig. 129), have a stem bearing green leaves and multicellular root-hairs; while others bear unicellular root-hairs, having either a thalloid body as the

FIG. 129.

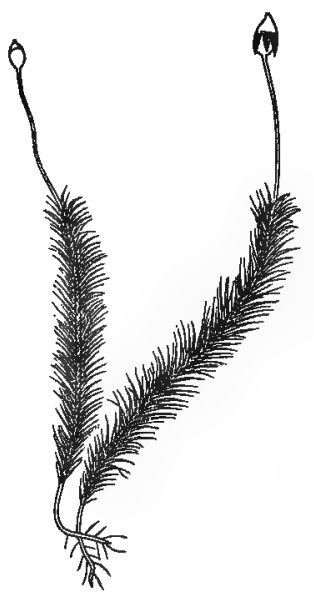

FIG. 129.-Kosugigoke (Pogonatum sp.).

Zenigoke (Fig. 3) or a stem bearing green leaves as the Hime-urokogoke (Frullania). Those of the former kind are called Musci, and those of the latter Hepaticce.

Bryophyta are thus divided into the two classes Musci and Hepaticæ.

$$
\text { BRYopHYTA } \begin{cases}\text { Class I. } & \text { Musci. } \\ \text { Class II. Hepatice. }\end{cases}
$$


Group III. THALLOPHYTA.

Some plants of this group, as the Matsudake (Fig. 4) and Kabi (Mucor), do not contain chlorophyll; while others, as the Kombu (Fig. 130) and Aonori (Enteromorpha compressa), contain chlorophyll. The former we term Fungi, the latter Alga.

Fig. 130.

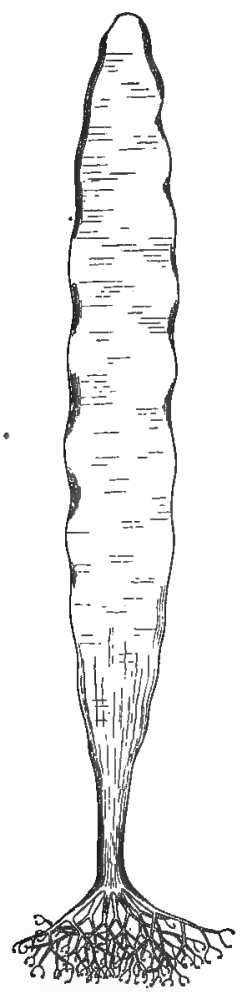

Fra. 130.-Kombu (Laminaria japonica).

Thallophyta are thus divided into the two classes Fungi - :and Algæ. 


\section{ThaLlopHYTA $\left\{\begin{array}{l}\text { Class I. Fungi. } \\ \text { Class II. Algæ. }\end{array}\right.$}

General olassification of Cryptogamæ are represented in the following table.

$$
\text { CRYPTOGAM सE }\left\{\begin{array}{l}
\text { Group I. Pteridophyta }\left\{\begin{array}{l}
\text { Class I. Filicinæ. } \\
\text { Class Ir. Lyeopodinæ. } \\
\text { Class III. Equisetinæ. }
\end{array}\right. \\
\text { Group II. Bryophyta }\left\{\begin{array}{l}
\text { Class I. Musci. } \\
\text { Class II. Hepaticæ. }
\end{array}\right. \\
\text { Group III. Thallophyta } \begin{cases}\text { Class I. Fungi. } \\
\text { Class II. Algæ. }\end{cases}
\end{array}\right.
$$

\section{SUMMARY.}

Phanerogama are those plants which produce flowers.

Cryptogama are those plants which do not produce flowers.

Angiosperma are those Phanerogamm whose ovules are enclosed in an ovary.

Gymnosperma are those Phanerogamæ whose ovules arc not enclosed in an ovary.

Dicotylea are those Angiospermæ which have dicotyledonous seeds.

Monocotylee are those Angiospermæ which have monocotyledonous. seeds.

Dialypetala are those Dicotyleæ which have dialypetalous flowers.

Gamopetala are those Dicotyleæ which have gamopetalous flowers.

Apetalce are those Dicotyleæ which have apetalous flowers.

Thalamiflore are those Dialypetalæ which have free dialypetalous: flowers.

Calyciflorce are those Dialypetalæ which have adherent dialypetalous flowers.

Gamopetala Epigyne are those Gamopetalæ which have epigynous. gamopetalous flowers.

Gamopetala Hypogyne are those Gamopetalæ which have hypogynous: gamopetalous flowers.

Apetala Epigyna are those Apetalæ which have epigynous apetalous: flowers.

Apetala Hypogyna are those Apetala which have hypogynous apetalous: flowers.

Petaloidea are those Monocotyleæ which have showy flowers. 
Nudiforce are those Monocotylex, which have inconspicuous scaly floral envelopes or want them.

Petaloidec Epigynce are those Petaloideæ which have epigynous flowers.

Petaloidea Hypogyna are those Petaloider which have hypogynous flowers.

Spadiciflora are those Nudifloræ, which have large scattered bracts: covering clusters of flowers.

Glumiflore are those Nudifloræ which have small scattered bracts.

Pteridophyta are those Cryptogannæ which have fibrovascular bundles.

Bryophyta are those Cryptogamæ, which want fibrovascular bundles having either a stem with green leaves or a thalloid body with more or less developed epidermis.

Thallophyta are those Cryptogamæ, which want fibrovascular bundles. and true epidermis, presenting no differentiation of root, stem, and loaf.

Filicince are those Pteridophyta which have large well developed leaves.

Lycopodina are those Pteridophyta which have small scattered leaves.

Equisetina are those Pteridophyta which have small verticillate leaves.

Musci are those Bryophyta which have multicellular root-hairs.

Hepatica are those Bryophyta which have unicellular root-hairs.

Fungi are those Thallophyta, which do not contain chlorophyll.

Alge are those Thallophyta which contain chlorophyll.

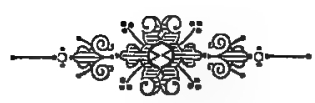





\section{N D E X.}

Absorption 119,127

Aleurone-grains 104 Algm $137,138,139$

Androcium $48,52, \quad 84$ Angiospermæ ... 129, 130, 134, 138 Angular divergence .........39, 82 Apetalæ ...........131, 132, 134 138 , Epigynæ......132, 134, 138 " Нypogynæ ...132, 134, 138

Blade 22

Bract 47,74

Bryophyta $. .134,136,138,139$

Calycifloræ $131,134,138$

Calyx $47,48,83$

Cambium 113

Carpel 59,86

Cataphyllary leaves $\ldots . . .46,83$ Cell ........ 59, 86, 97, 98, 108 Cell-division ............... 108, 109 Cell-sap $\ldots \ldots \ldots .97,98,103,109$ Cell-wall 97, 98, 102, 103, 108, 118 Chlorophyll-

corpuscies 103, 104, 105, 109, 123 Conjugation $.108,109$

Constructive metabolism ...... 123 Corolla. $48,50,84$ Cotyledons 69,88

Cryptogamæ...... 129, 130, 134, 138 Crystalloids .................... 104 Crystals $104,106,109$ Definite inflorescence..... 76, 89 Destructive metabolism ........ 124 Dialypetalæ $.131,134,138$
Dicotyleæ $.130,131,134,138$

Electricity 126

Embryo 68,87

Epidermal system......112, 113, 114، Epidermis 113,114 Equisetinæ $135,136,138,139$

External forces .................. 124 Excretion 124

Fibro-vascular bundle.112, 113, 114 . Fibro-vascular system ......112, 114 Filament ....................52; 84, Filicinæ..........135, 136, 138, 139 Floral leaves..................47, 83 Flower ..................46, 47, 83 Foliage leaves ................21, 80 Fruit ..................60, 62, 86 Fundamental system........112, 114 Fungi .................137, 138, 139 Gamopetalæ ......131, 132, 134, 138 Glumifloræ............133, 134, 139 Gravitation ..............125, 126 Growth ..............122, 126, 128 Gymnospermæ ...129, 130, 134, 138 Gyncecium ............48, 59, 85 Hairs ..........5, 93, 95, 113, 114 Hepaticæ .............136, 138, 139 Hypsophyllary leaves...47, 74, 83 Indefinite inflorescence ......76, 89 Inflorescence ...................75, 89 Insectivorous leaves ...........46, 83 Iutercellular spaces ........115, 116 Internode ...................... I2, 18 Irritability $\quad \ldots \ldots \ldots \ldots . .126,127,128$ 
Iamina.

22, 23, 80

Leaf. $.5, \quad 19,80$

Leaf-sheath $.22,36,80$

Leaf-stalk 22

Light 125

Lycopodinæ $135,136,138,139$ Markings $.99,101$

Metabolism 127

Modified leaves $.21,44,80$ Monocotyleæ.130, 132, 133, 134, 138 Monothalamic fruits 63,86

Movement of water, etc. 121 " of gases 122

Musci $136, \cdot 138,139$

Nervation. 23

Yode $.12,18$

Nucleus $.97, \quad 98$

Nudilloræ $133,134, \quad 139$

Nutrition 117,127

Ovary $.59,86$

Ovules 59,86

Parenchyma $110,111,114$ Parenchymatous cells ......107, 109 Pedicel 75

Peduncle. 75

Petaloideæ $133,134,138$

" Epigynæ ...133, 134, 139 Hуроgупæ...133, 134, 139

Petals 50,84

Petiole $22, \quad 36, \quad 80$

Phanerogamæ ...129, 133, 134, 138 Phloëm $112,113,114$ Physiology of nutrition ........ 117 " of reproduction...117, 128 Placenta $59,61,86$

Pollen. $.53,85$

Polythalamic fruits $\ldots 63,68,86$ Præfoliation 91,93

Primordial cells
Prosenchyma $110,111,114$ Prosenchymatous cells.....107, 109 Protoplasm...97, 98, 102, 103, 109 Pteridophyta.134, 135, 136, 138, 139 Receptacle ....................... 75 Respiration $118,119,127$ Root $.5 ; \quad 7,10$ Seed $.59,68,87$

Sepals $.48,83$

Spadicifloræ $133,134,139$ Spines 46,83 Spore-bearing leaves ...47, 79, 83 Spores $79, \quad 89$

Stamens.....................52, 84: Starch-grains.103, 105, 104, 109, 123 Stem $4,11,18$ Stigma 59,86 Stipules .36, 80

Stomata $113,114,118$

Style 59,86

Temperature ..................... 124 Tendrils $.46,83$

Thalamifloræ ...........131, 134, 138 Thallophyta .....134, 137, 138, 139 Thallus

Tissues ...............110, 114, 124 Tissue-systems .........111, 113, 114 Tracheæ ............................ 111 Transpiration ...117, 118, 122, 127 Trees 13,19

Trichomes ........................ 5 Vascular cells ................107, 109 " tissue .............110, 114 Veins ...........................23, 80 Venation ...............23, 27, 80 Vernation .......................... 91 Wood .............................. 112 Xylem $.112,113,114$ 


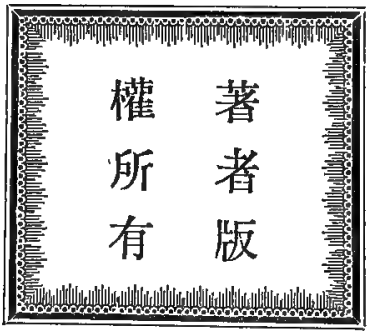

明 明

治 治

二

六 六

年 年

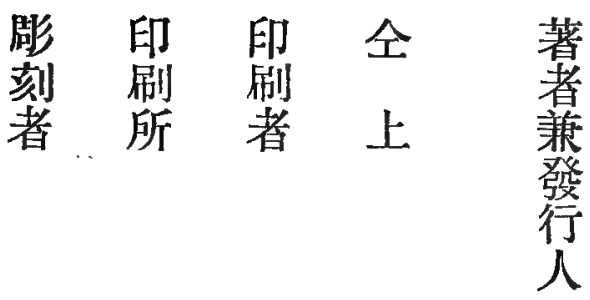

二 二

月 月

十十

四二

日 日

出 印

版 刷

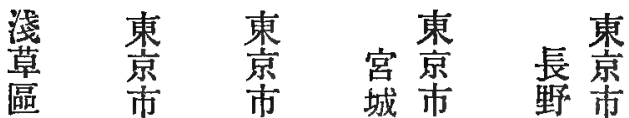

西旦㲘本縣本

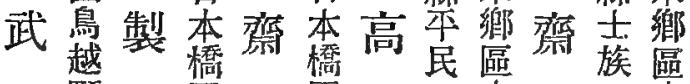

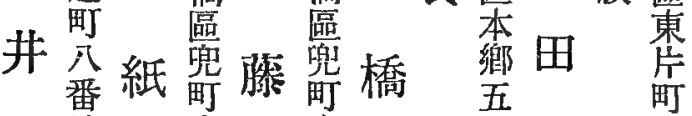

鉚地番喜

首动 百

之分地章地章立太主

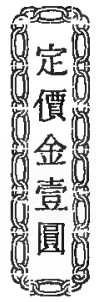

助 社達 臣地郎地 






